\title{
BioGreenhouse
}

\section{Handbook for Composting and Compost Use in Organic Horticulture}

Edited by André W.G. van der Wurff, Jacques G. Fuchs, Michael Raviv and Aad J. Termorshuizen

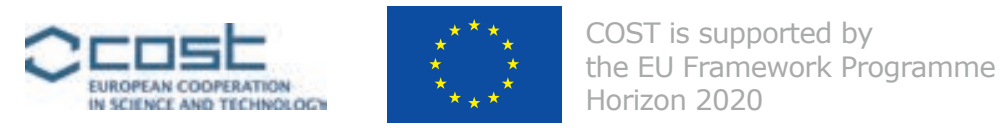

\section{Compost}




\section{Correct citation of this document:}

Van der Wurff, A.W.G., Fuchs, J.G., Raviv, M., Termorshuizen, A.J. (Editors) 2016. Handbook for Composting and Compost Use in Organic Horticulture

BioGreenhouse COST Action FA 1105, www.biogreenhouse.org.

ISBN: 978-94-6257-749-7

DOI (Digital Object Identifier): http://dx.doi.org/10.18174/375218

\section{Pictures}

All pictures are supplied by the authors of this handbook.

\section{Disclaimer}

The information in this handbook is based on the expert opinions of the various authors. Neither they, nor their employers, can accept any responsibility for loss or damage occurring as a result of following the information contained in this handbook.

This work or parts of it may be multiplied provided reference to this work as written in the correct citation of this document.

\section{Acknowledgement}

This handbook is based upon work from COST Action FA1105 BioGreenhouse, supported by COST (European Cooperation in Science and Technology). The authors are grateful for financial support and the opportunity to build this network provided by COST. They wish to thank many colleagues for their assistance in providing the material for this handbook, Mr. Roger Hitchings for proofreading and Ms. José Frederiks (Wageningen UR Greenhouse Horticulture) for processing layout and printing.

Link to the Action: http://www.cost.eu/COST_Actions/fa/FA1105 and: http://www.biogreenhouse.org/ 


\section{Table of contents}

$\begin{array}{lr}\text { Preface } & 7\end{array}$

$\begin{array}{lr}\text { Authors and Oganisations } & 9\end{array}$

$\begin{array}{lr}\text { Overview } & 11\end{array}$

$1 \quad$ Compost and soil ecosystem resilience in organic greenhouses

$\begin{array}{llr}1.1 & \text { Introduction } & 13\end{array}$

$\begin{array}{llr}1.2 & \text { Resilient farming systems } & 14\end{array}$

1.2.1 Resilience and biodiversity 14

1.2.2 Farm management options: risk management or resilience 15

1.2.3 Resilience and risk management in organic greenhouse production 16

$\begin{array}{llr}1.3 & \text { Composts and soil ecosystem resilience } & 18\end{array}$

$\begin{array}{lll}\text { 1.3.1 Organic matter storage and transformation } & 18\end{array}$

1.3.2 Storage, transport and transformation of nutrients 21

1.3.3 Soil structure, aggregate stability, water storage and transport $\quad 22$

$\begin{array}{lll}1.4 & \text { Visual soil assessment } & 23\end{array}$

$\begin{array}{llr}1.5 & \text { References } & 25\end{array}$

$2 \quad$ Compost types, feedstocks and composting methods

$\begin{array}{llr}2.1 & \text { Compost types } & 29\end{array}$

$\begin{array}{ll}2.2 \text { Compost feedstocks } & 31\end{array}$

$\begin{array}{lll}2.3 & \text { Compost starting mixes } & 33\end{array}$

\begin{tabular}{ll}
2.4 & Composting methods \\
\hline
\end{tabular}

$\begin{array}{ll}2.5 & 42 \\ 2.6 & \text { Compost maturity }\end{array}$

\begin{tabular}{ll}
2.6 & References \\
\hline
\end{tabular}

Microbiology of the composting process $\quad 45$

$\begin{array}{llr}3.1 & \text { The composting process } & 45\end{array}$

$\begin{array}{ll}3.2 & \text { What are microorganisms? } \\ 3.3\end{array}$

3.3 Where do the microorganisms in the compost come from? 46

3.4 Why do microorganisms do it? 46

3.5 What microorganisms need to be able to do all the work? 47

$\begin{array}{lll}3.5 .1 \quad \text { Nutrients } & 47\end{array}$

$\begin{array}{lll}3.5 .2 & \text { Oxygen } & 48\end{array}$

$\begin{array}{lll}3.5 .3 & \text { Water } & 49\end{array}$

3.6 How do microorganisms do it? $\quad 49$

3.6.1 Warming-up Phase $\left(25-40^{\circ} \mathrm{C}\right) \quad 49$

3.6.2 Thermophilic Phase $\left(40-65^{\circ} \mathrm{C}\right) \quad 49$

3.6.3 Cooling Phase (Second Mesophilic Phase) 50

3.6.4 Maturation and Curing Phase $\quad 50$

$\begin{array}{lll}\text { 3.6.5 Compost maturity } & 50\end{array}$

$\begin{array}{ll}3.7 & \text { References } \\ \end{array}$ 
4.1 Production control measures $\quad 53$

4.1.1 Temperature $\quad 53$

4.1.2 Moisture content $\quad 56$

$\begin{array}{lll}4.1 .3 & \text { Oxygen content } & 57\end{array}$

$\begin{array}{lll}4.1 .4 & \text { Available nitrogen } & 57\end{array}$

4.1.5 Maturity level $\quad 58$

\begin{tabular}{lr}
4.2 & Use of control measures \\
\hline
\end{tabular}

4.2.1 Maturity level and phytotoxicity $\quad 59$

4.2.1.1 NO3-N/Nmin-ratio $\quad 59$

4.2.1.2 Phytotoxicity tests 59

4.2.1.3 Heavy metals $\quad 60$

$\begin{array}{lll}\text { 4.2.1.4 Nutrient contents } & 60\end{array}$

$\begin{array}{lll}\text { 4.2.1.5 } & \mathrm{pH} \text {-value } & 60\end{array}$

$\begin{array}{lll}4.2 .1 .6 & \text { Salt content } & 61\end{array}$

$\begin{array}{lll}\text { 4.2.1.7 Intensity of colour extract } & 61\end{array}$

$\begin{array}{lll}\text { 4.2.1.8 Pathogens and weeds } & 61\end{array}$

$\begin{array}{ll}4.3 \text { Conclusion } & 62\end{array}$

$\begin{array}{lll}4.4 & \text { References } & 62\end{array}$

$\begin{array}{lll}5.1 & \text { Fate of pathogens during composting } & 63\end{array}$

5.2 Risk of pathogens and weeds present in residues offered for composting 64

$\begin{array}{ll}5.3 & \text { Quality of the composting procedure } \\ \end{array}$

$\begin{array}{ll}5.4 & 66\end{array}$

$\begin{array}{llr}5.5 & \text { References } & 68\end{array}$

$\begin{array}{lll}6.1 & \text { Introduction } & 71\end{array}$

6.1.1 What is disease suppressiveness of soil? $\quad 71$

$\begin{array}{lll}6.1 .2 & \text { How can we recognize a suppressive soil? } & 71\end{array}$

6.1.3 Where can we find suppressive soils?

6.1.4 How can we increase disease suppressiveness? $\quad 72$

6.2 Use of compost: A key farming practice to increase suppressiveness $\quad 73$

$\begin{array}{lll}6.3 & \text { Suppressiveness against specific pathogens } & 73\end{array}$

$\begin{array}{ll}6.4 & 75\end{array}$

$\begin{array}{lll}\text { 6.4.1 Proposed effect of compost } & 75\end{array}$

$\begin{array}{ll}\text { 6.4.2 Effect on pathogen/ nematode } & 75\end{array}$

$\begin{array}{ll}\text { 6.4.3 Effect on plants } & 75\end{array}$

$\begin{array}{lll}6.5 & \text { Important considerations } & 76\end{array}$

$\begin{array}{ll}6.6 & \text { References } \\ \end{array}$ 
$\begin{array}{llr}7.1 & \text { Introduction } & 79\end{array}$

$\begin{array}{llr}7.2 & \text { Anaerobic digestion processes } & 80\end{array}$

$\begin{array}{ll}7.3 \text { Characteristics of compost and digestate } & 81\end{array}$

$\begin{array}{lll}\text { 7.3.1 Total nutrient contents } & 81\end{array}$

$\begin{array}{lll}7.3 .2 & \text { Mineral nitrogen } & 81\end{array}$

$\begin{array}{lll}7.3 .3 & \text { Organic matter } & 82\end{array}$

$\begin{array}{lll}7.3 .4 & \text { Salinity } & 82\end{array}$

$\begin{array}{lll}\text { 7.3.5 } \mathrm{pH} & 83\end{array}$

$\begin{array}{lll}\text { 7.3.6 Plant compatibility } & 83\end{array}$

$\begin{array}{lll}\text { 7.3.7 Hygiene } & 83\end{array}$

$\begin{array}{lll}\text { 7.3.8 Organic contaminations } & 84\end{array}$

$\begin{array}{lll}7.4 & \text { Utilization of compost and digestate } & 84\end{array}$

$\begin{array}{lll}\text { 7.4.1 General remarks } & 84\end{array}$

$\begin{array}{lll}7.4 .2 & \text { Target fertilization } & 84\end{array}$

7.4.3 Target improvement of soil structure $\quad 85$

7.4.4 Target plant growing media (substitute of peat) 85

\begin{tabular}{ll}
7.5 & Application techniques \\
\hline
\end{tabular}

7.5.1 Digestate use in greenhouses $\quad 85$

$\begin{array}{lll}7.5 .2 & \text { Compost use in greenhouses } & 85\end{array}$

7.5.3 Compost use in plant media $\quad 86$

$\begin{array}{llr}7.6 & \text { Conclusions } & 86\end{array}$

$\begin{array}{llr}7.7 & \text { References } & 86\end{array}$

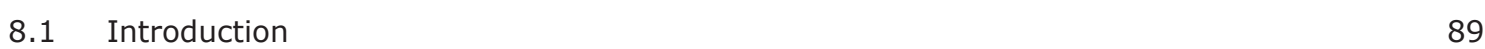

8.2 Influence of soil and growing media properties 90

$\begin{array}{lll}8.2 .1 & \text { Soil } & 90\end{array}$

$\begin{array}{ll}\text { 8.2.2 Growing media } & 90\end{array}$

$\begin{array}{ll}\text { 8.2.3 Conclusion } & 90\end{array}$

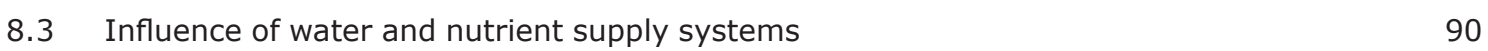

$\begin{array}{lll}8.3 .1 & \text { Soil } & 90\end{array}$

$\begin{array}{lll}\text { 8.3.2 Growing media } & 91\end{array}$

$\begin{array}{ll}\text { 8.3.3 Conclusion } & 91\end{array}$

8.4 Compost functions in soil and growing media 92

$\begin{array}{lll}8.4 .1 & \text { Soil } & 92\end{array}$

8.4.2 Growing media 93

$\begin{array}{lll}\text { 8.4.3 Conclusion } & 94\end{array}$

$\begin{array}{ll}8.5 & \text { Negative function indicators }\end{array}$

$\begin{array}{lll}\text { 8.5.1 Conclusion } & 94\end{array}$

\begin{tabular}{ll}
8.6 & Measuring quality \\
\hline
\end{tabular}

8.6.1 Available versus total element analysis 95

8.6.2 Choice of extraction 96

$\begin{array}{lll}\text { 8.6.3 Reporting } \mathrm{mg} \text { or } \mathrm{mmol} & 97\end{array}$

$\begin{array}{ll}\text { 8.6.4 Using \%-v/v or \%-w/w } & 97\end{array}$

$\begin{array}{ll}\text { 8.6.5 Conclusion } & 97\end{array}$

$\begin{array}{llr}8.7 & \text { General conclusion } & 98\end{array}$

$\begin{array}{llr}8.8 & \text { References } & 98\end{array}$ 
$\begin{array}{llr}9.1 & \text { Compost sampling } & 99\end{array}$

\begin{tabular}{ll}
9.2 & Assessments with own senses \\
\hline
\end{tabular}

$\begin{array}{lll}\text { 9.2.1 Colour of the compost } & 99\end{array}$

$\begin{array}{ll}9.2 .2 \text { Odours } & 100\end{array}$

$\begin{array}{ll}\text { 9.2.3 Structure of the compost } & 100\end{array}$

$\begin{array}{ll}\text { 9.2.4 Wood breaking test } & 101\end{array}$

9.3 Interpretation of measurements and analyses 101

$\begin{array}{ll}\text { 9.3.1 Composting process protocol } & 101\end{array}$

$\begin{array}{ll}\text { 9.3.2 Chemical analyses } & 101\end{array}$

$\begin{array}{ll}\text { 9.3.3 Phytotoxicity tests } & 102\end{array}$

$\begin{array}{ll}\text { 9.4 How to choose the right compost for the desired application } & 102\end{array}$ 


\section{Preface}

In 2008, at the 16th IFOAM Organic World Congress in Modena (IT), about 25 participants expressed their interest in working together in the field of research and development for organic greenhouse or protected horticulture. A two-day workshop was organised in Cologne in 2009 to discuss the subject and to give further support to the collaboration. 45 people from across Europe and from Canada attended this workshop. It was decided to pursue joint efforts in the field of organic protected horticulture, with particular respect to planting material; soil fertility; composting; water management; disease and pest management; climate management and energy conservation; and sustainability. The group also agreed to submit a COST (European Cooperation in Science and Technology) Action on the same subject. The proposal "Towards a sustainable and productive EU organic greenhouse horticulture" (BioGreenhouse) was submitted in mid-2011.

At the end of 2011, COST approved this proposal as COST Action FA1105 (see http://www.cost.eu/COST_ Actions/fa/FA1105 and www.biogreenhouse.org), which set out to build a network of experts working in the field of organic protected horticulture. The aims of the Action are to develop and to disseminate knowledge of new and improved production strategies, methods and technologies for the support of sustainable and productive organic greenhouse/protected horticulture in the EU. This has involved coordinated international efforts and in total, 27 participating COST countries and two COST Neighbouring countries took part in the Action.

This Action offered the framework and funds for experts of the participating countries to meet and to work together in Working Groups focusing on the objectives of the Action. The objectives related to composting and compost use, were: to design strategies for making and using of composts and other amendments in order to improve soil fertility and to achieve disease suppression.

More than 10 experts from different regions and backgrounds worked together on this topic. They have approached their task with commitment by reviewing compost use for organic greenhouses and nurseries and by describing the composting process, various compost types, the microbiological background and the management of the compost process. Attention is also paid to the hygienic aspects of composting, to disease suppressiveness and to the use of compost in growing media; Compost is also compared with digestate and finally an explanation of how growers can assess compost quality and use is given.

Together they produced this publication:

\section{"Handbook for composting and compost use in organic horticulture"}

I believe this handbook will prove a unique source of information for all people involved in organic horticulture; for growers, compost producers, researchers, students, teachers, consultants and suppliers. This booklet could serve as a source to improve the composting process and the compost use.

On behalf of the COST Action BioGreenhouse, I want to thank the team of the authors for the work they have done, their cooperative spirit and their perseverance. This work will definitely contribute to better composting and better composts, and to an even more sustainable organic horticulture.

Rob J.M. Meijer

Wageningen UR Greenhouse Horticulture

Chair, COST Action FA1105 Biogreenhouse 
8 I Handbook for Composting and Compost Use in Organic Horticulture 


\section{Authors and Oganisations}

Beatrix Alsanius is professor in Horticulture at the Department of Biosystems and Technology, Swedish University of Agricultural Sciences, Alnarp, Sweden (http://www.slu.se/en/). Email: beatrix.alsanius@slu.se.

Chris Blok is research scientist for Rooting Media and Plant Nutrition at Wageningen University \& Research centre, Greenhouse Horticulture, Bleiswijk, The Netherlands (http://www.glastuinbouw.wur.nl/UK/). Email: Chris.Blok@wur.nl.

Willemijn J.M. Cuijpers is researcher soil health and fertility at Louis Bolk Institute, Driebergen, The Netherlands (www.louisbolk.org). Email: w.cuijpers@louisbolk.nl.

Soraya C. França is senior scientist plant pathology at Biobest, R\&D Microbials, Westerlo, Belgium (http://www. biobestgroup.com). Email: soraya.franca@biobest.be.

Jacques G. Fuchs is senior scientist plant pathology and soil quality at the Research Institute of Organic Agriculture FiBL, Frick, Switzerland (www.fibl.org). Email: jacques.fuchs@fibl.org.

Leen Janmaat is senior advisor and researcher sustainable agriculture at Louis Bolk Institute, Driebergen, The Netherlands (http://www.louisbolk.org) Email: l.janmaat@louisbolk.nl.

Michael Raviv is an emeritus professor of Environmental Horticulture at the Agricultural Research Organization, Newe Ya'ar Research Center, Israel. Email: mraviv@volcani.agri.gov.il.

Marta A. Streminska is microbial ecologist at Wageningen University \& Research centre, Greenhouse Horticulture, Bleiswijk, The Netherlands (http://www.glastuinbouw.wur.nl/UK/).

Email: Marta.Streminska@wur.nl.

Aad Termorshuizen is agronomist at SoilCares Research, which is part of the Dutch Sprouts group, Wageningen, The Netherlands (www.dutchsprouts.com). Email: aad.termorshuizen@soilcaresresearch.com.

André W.G. van der Wurff is senior scientist plant pathology and soil quality at Wageningen University \& Research centre, Greenhouse Horticulture, Bleiswijk, The Netherlands (http://www.glastuinbouw.wur.nl/UK/). Email: Andre.vanderWurff@wur.nl. 
10 I Handbook for Composting and Compost Use in Organic Horticulture 


\section{Overview}

The Growers Handbook on Compost is divided into nine chapters:

Chapter 1 presents the ecosystem approach in organic farming, explaining the concept of resilience and biodiversity, and how different farm management styles may incline more towards risk management or towards building long-term resilience. Soil ecosystem resilience is at the basis of organic farming systems, and the chapter highlights how compost can contribute to building resilience into the ecosystem services that the soil provides. When soil imbalance occurs, it is important for the grower to have a good understanding of the different aspects of his or her own soil, before deciding what management options are available. The chapter also explains how a visual soil assessment in the form of a spade test can be carried out, to identify the area in which soil problems exist. From there, soil management decisions can be made, regarding the right type and quality of soil amendments, the application rate, and/or the depth and frequency of tillage.

Chapter 2 starts with a brief overview of the characteristics of different feedstocks which can be used in the composting process, and addresses specifically the nutrient contents of different types of manure. Depending on the carbon and nitrogen contents, manure can either be directly composted or mixed with structure- and carbon rich-materials. It also discusses the effects of the application of fresh manure compared to composted manure on amended soil. The next part of the chapter discusses the technical aspects of the composting process and the requirements for the preparation of starting mixes. Different compost types are described. The last part of the chapter gives an overview of the different composting systems that are applied in Europe: from farmer-field edge methods to commercial hall composting.

Chapter 3 discusses the microbiology of the composting process. The most important groups of microorganisms involved in the composting process are discussed. The feedstocks that are used in compost production determine the availability of energy in the form of various organic compounds and the presence of nutrients, notably nitrogen. The roles of different microorganisms in the transformation of organic compounds and nitrogen in the various stages of the composting process are discussed. The different phases of the hot composting process are discussed in detail, including the role of specific bacteria and fungi. Finally stability and maturity are defined and the difference between them is explained

In Chapter 4, the management of the composting process is described in terms of parameters that are necessary to control production, including temperature, moisture content, oxygen content and available nitrogen. The maturity level at the end of the composting process can be determined by several tests. The last part of this chapter discusses the most important quality aspects of the final compost product. These include nutrient contents, $\mathrm{pH}$ value, salt contents, heavy metal contents, the intensity of colour extracts, and the presence of pathogens and weeds.

Chapter 5 describes the hygienization aspects of composting. This includes not only plant pathogens and weeds, but also animal and human pathogens. The mechanisms through which pathogens are eradicated during the composting process are described, and the relevant aspects of risk pathogens are discussed. The next part of the chapter describes the main entries for plant pathogens and human pathogens in compost feedstocks. The last part of the chapter describes the critical aspects of the composting process, where improper handling may lead to failure of inactivation of pathogens.

In Chapter 6 the phenomenon of natural disease suppression is described: What is it exactly and how can it be recognized in practice. Furthermore, the chapter deals with the use of compost to increase disease suppression and how compost may aid to combat soil-borne diseases such as plant pathogenic fungi, bacteria and nematodes.

Chapter 7 describes the main differences between compost (produce aerobically) and digestate (resulting from anaerobic digestion). Both have specific characteristics which influence their utilization. Digestate has a stronger but shorter term fertilization effect than compost, but compost has better medium- and long-term effects on humus content and soil structure than digestate. So, depending on the target use, compost and digestate have specific advantages and disadvantages, opportunities and limits. 
Besides the use of compost in the field, it may be used as well in growing media. This is described in Chapter 8: It is described how compost influences diverse properties of soil and growing media such as water content and nutrient supply. In addition, it is indicated how the quality of the compost can be measured.

Chapter 9 describes how growers can assess compost quality in order to choose the appropriate compost for the target application. There is a range of different methods that can help the grower to choose: observation with own senses, simple chemical analyses and bio-tests. In this chapter, these methods are briefly described and the interpretation of the obtained results is discussed. 


\title{
1 Compost and soil ecosystem resilience in organic greenhouses
}

\author{
Willemijn J.M. Cuijpers, Leen Janmaat and Jacques G. Fuchs
}

\section{In short:}

- The use of compost in organic farming systems matches with the principles of ecology, and the efforts to reduce inputs by reuse and recycling of materials and energy.

- In order to enhance the level of resilience, including the self-regulating capacity of the farming system, management strategies should foster high levels of biodiversity.

- The application of compost can support soil ecosystem resilience by enhancing organic matter storage and transformation, nutrient storage and mineralization, and by improving aggregate stability leading to improved soil structure, water transport, water holding capacity and disease suppressiveness.

- In order to decide the type and amount of organic amendment, a soil assessment can be helpful to identify the areas in which the soil, soil organisms and crops should be supported most.

\section{$1.1 \quad$ Introduction}

According to the International Federation of Organic Agriculture Movements (IFOAM), organic farming is "a production system which sustains the health of soils, ecosystems and people. It relies on ecological processes, biodiversity and cycles adapted to local conditions, rather than the use of inputs with adverse effects ${ }^{\prime \prime}$. Organic agriculture is a whole systems approach (Figure 1.2), which involves understanding and supporting processes that contribute to the four principles of health, ecology, fairness and care. The organic production system is more than a system that is just concerned with including or excluding certain types of inputs. One of the four principles of organic farming is the principle of ecology. Because it is rooted in ecological systems, "organic production is to be based on ecological processes, and recycling (...). Inputs should be reduced by reuse, recycling and efficient management of materials and energy in order to maintain and improve environmental quality and conserve resources" ${ }^{11}$. Compost, as a product of recycling processes, can be a very appropriate input material for organic farming, provided the composting process is well-managed, the input materials are free of contaminants, and the resulting product is applied according to the system's ecological needs.
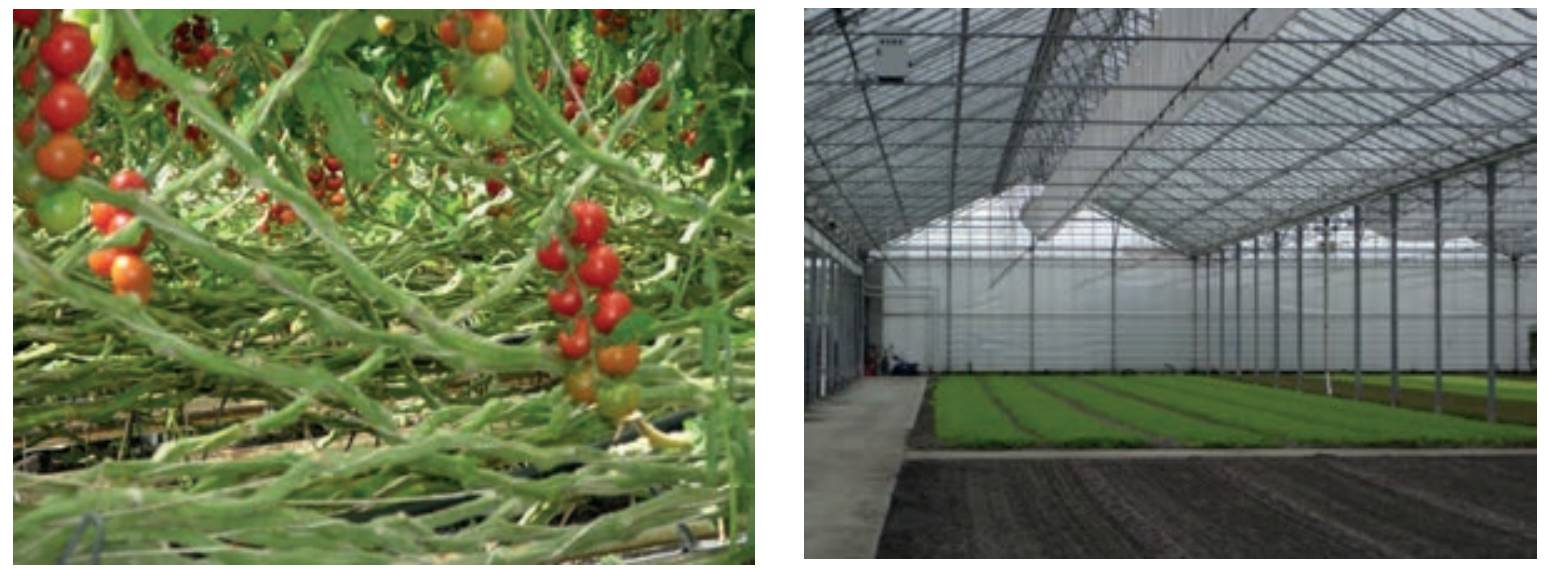

Figure 1.1 Organic greenhouse production systems can vary greatly in intensity. Left: intensively managed organic greenhouse, with crop rotation of tomato, sweet pepper and cucumber. Right: extensively managed greenhouse, with leafy vegetables in winter, heated only to keep the greenhouse frost-free. 
Compost is a very important input material for organic greenhouse production. Organic greenhouse production may vary in the level of intensity (Figure 1.1), but it is generally a system with high turnover rates of organic matter, high inputs of both nutrients and energy, and high production levels. Compost is used as an important source of organic matter and nutrients in greenhouse horticulture, and is an important component of growing media for nurseries. Compost plays an important role in building a resilient farming system, by providing both the energy sources and the nutrients to sustain soil biodiversity. This chapter highlights the most important soil functions, how they are mediated by soil organisms, and what it takes to make farming systems resilient. Nourishing these soil organisms through the use of compost, strengthens the ecosystem services that these organisms provide.

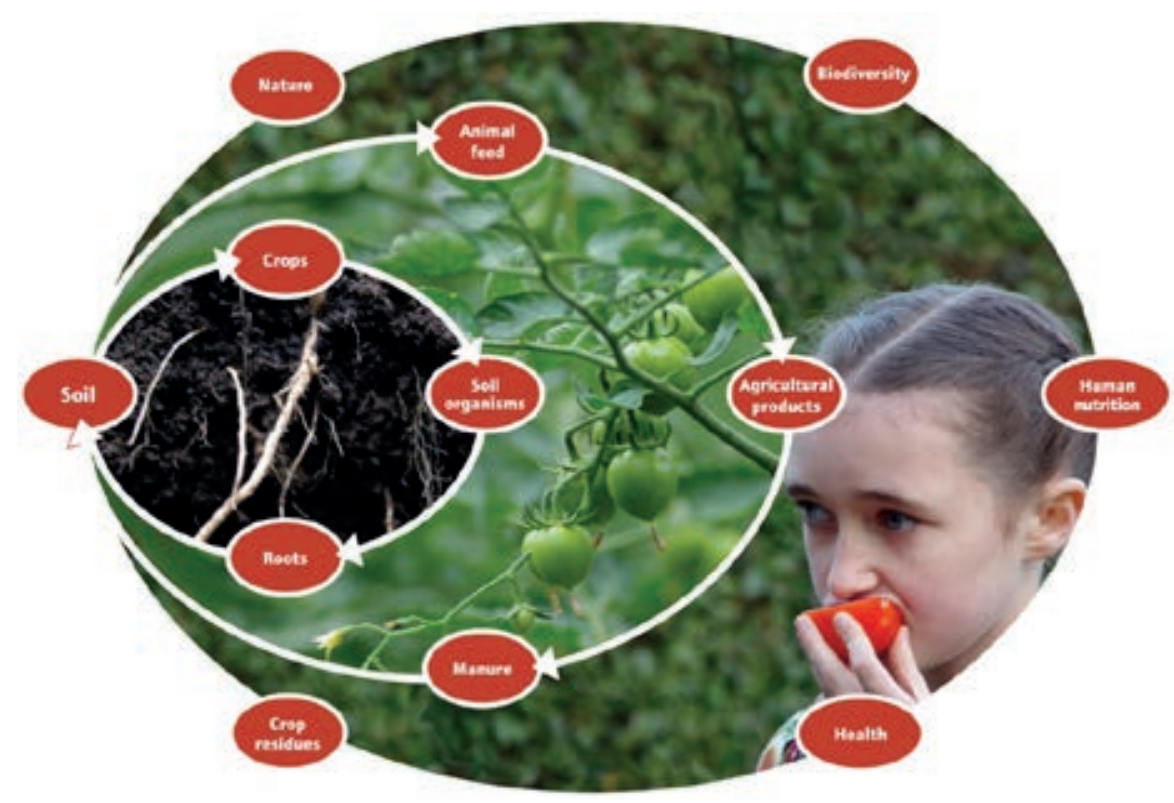

Figure 1.2 Organic greenhouse production: a whole systems approach, including the four principles of health, ecology, fairness and care. Recognizing processes, cycles and interactions are important components of building organic production systems.

\subsection{Resilient farming systems}

\subsubsection{Resilience and biodiversity}

The concept of resilience in ecology has been developed from the idea that organic systems are naturally and constantly changing. Organic systems are characterized by continuous changes caused by external factors as opposed to mechanical systems in which consistent behavior is desirable. Stability means that a system is able to stay very close to the equilibrium state after being disturbed. The more rapidly it returns, with the least fluctuation, the more stable it is. Resilience is something different. It can be defined by the ability of a system to undergo disturbance, but at the same time maintain its functions. By moving the focus from stability to resilience, we are not so much occupied by the maintenance of a fixed equilibrium state. The resilience view emphasizes the need to keep options open and to value heterogeneity, in order to deal with every kind of future event $^{2}$. Resilience could be measured in three ways ${ }^{3}$ :

- The amount of change a system can undergo, and still retain its controls on function and structure;

- The degree to which the system is capable of self-organization;

- The ability to build and increase the capacity for learning and adaptation.

The level of biodiversity of a system can make the difference between the amount of stress or resilience that the system will experience when a sudden change occurs. Biodiversity is needed in all agroecosystems to provide the required ecosystem functions ${ }^{4}$. Although a high biodiversity may not be critical under 'friendly' conditions, it might become important under changing circumstances. Biodiversity can be seen as a kind of insurance, 
or buffer, against environmental fluctuations. Species that are functionally 'redundant' at a certain point in time, may no longer be redundant when disturbances occur that destroy the species which carried out those functions earlier ${ }^{5}$. Some ecosystem functions are carried out by a large variety of species. One of the examples often mentioned is the decomposition of organic matter. Microbial redundancy may be relatively high in the decomposer community, coupled to a strong resilience. We are only just beginning to understand the complexity of soil decomposers, however, and different groups and species still have to be linked to rates and routes of soil organic matter processing ${ }^{6}$. It might be more appropriate to speak about 'niche complementarity ${ }^{77}$ instead of redundancy. Other soil functions are carried out by only a few organisms, e.g. deep-burrowing earthworm species who act as 'ecosystem engineers'. When they are dispelled by too intense tillage, their functions are not taken over by other organisms, resulting in reduced 'niche complementarity' and a weak resilience of this soil ecosystem function. It is necessary to deepen our knowledge of the functions of soil life, in order to develop a better understanding of how to support agroecosystem resilience. Soil organisms support the farmer in several ways ${ }^{8}$ :

- Storage, transport and transformation of carbon sources;

- Storage, transport and transformation of nutrients;

- Storage and transport of water and air;

- Providing carrying capacity and resistance to compaction;

- Providing resistance to erosion and sealing;

- Regulation of other soil biota (including soil-borne diseases);

- Detoxification and filtration of contaminants;

- Regulation of atmospheric composition.

\subsubsection{Farm management options: risk management or resilience}

Farm management styles could be classified as being located somewhere on a spectrum of measures, that are oriented towards risk management and control at one extreme, and oriented towards resilience and adaptation at the other. Since the start of the Green Revolution, farming systems have gradually developed to be more and more oriented towards the risk management model. Production systems have been simplified not only in terms of crop rotation, but also regarding the amount of genetic variation in both major staple crops, and also in vegetables and fruit crops. Risks of nutrient and water shortages have been addressed by the increase in use of chemical fertilizers and irrigation in these systems, and pathogens and pests have been suppressed by the application of chemical pesticides. While reducing the short-term risks, this system involves a continuous high level of control and inputs (Figure 1.3, left). The ball (representing a system state) can only stay in place by external forces (the arrows) which keep it from moving away. The environment shows no resilience: without the external controls, any disturbance will cause the ball to roll downwards. The system involves high long-term risks: when the underlying system becomes too degraded, control measures will either become ineffective or very costly.

At the other side of the spectrum is the resilience or adaptation model of farm management. The measures which are taken support the underlying system. They are not so much concerned with a fixed equilibrium state, but with the broader environment. The ball may move away from its original position, the situation may not be stable, but it will be able to carry out all the functions (Figure 1.3, right). Management strategies that increase resilience tend to focus on a high level of biodiversity and a greater variability within the production system. 


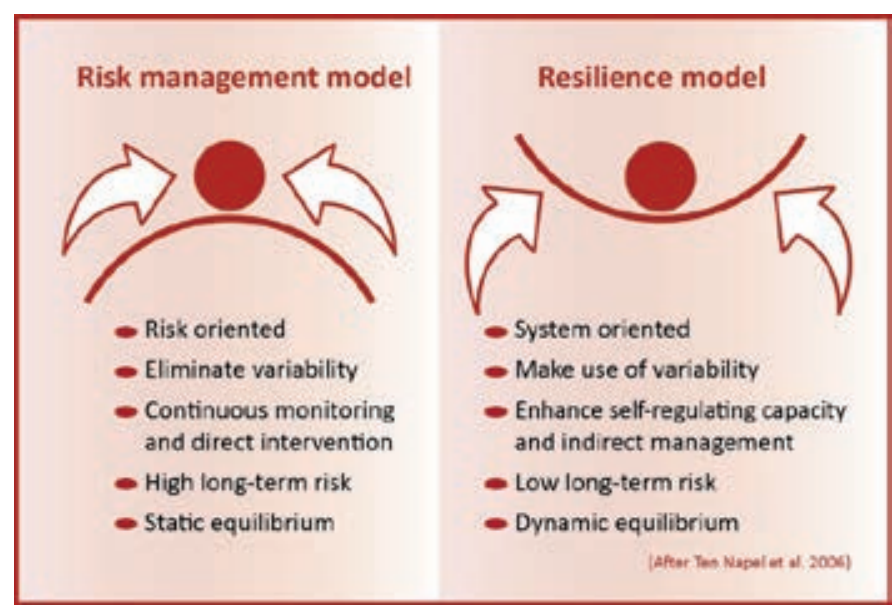

Figure 1.3 General characteristics of systems based on risk management, or control models (left) and resilience, or adaptation models (right) (adapted from ${ }^{9}$ ).

\subsubsection{Resilience and risk management in organic greenhouse production}

The resilience model plays a key role in organic farming systems. Organic agriculture is a whole-systems approach, which aims to enhance the self-regulating capacity of the ecological processes and which supports high levels of biodiversity (Figure 1.2). Managing an organic production system includes recognizing and supporting all the aspects and interactions which enhance the system's resilience. Management strategies in organic greenhouses are likewise based on supporting the entire ecological system. Management measures like crop rotation, rootstock selection, and the addition of sufficient amounts of high quality organic matter make the production system more resilient (Figure 1.4). But organic greenhouse production is also an intensive growing system. Crop rotation is generally narrowed down to those crops which are economically viable when cultivated under the roof of a high-value greenhouse construction. The growing season is lengthened by application of heating and cooling systems, requiring high levels of energy inputs. This increases production levels and turnover rates of organic matter and nutrients, demanding higher inputs of both organic matter and minerals. The farming system is also separated from the natural environment, making it dependent on the artificial introduction of pollinators and natural enemies of aphids and other pests. 


\section{SUSTAINABLE SOIL MANAGEMENT IN GREENHOUSE HORTICULTURE}

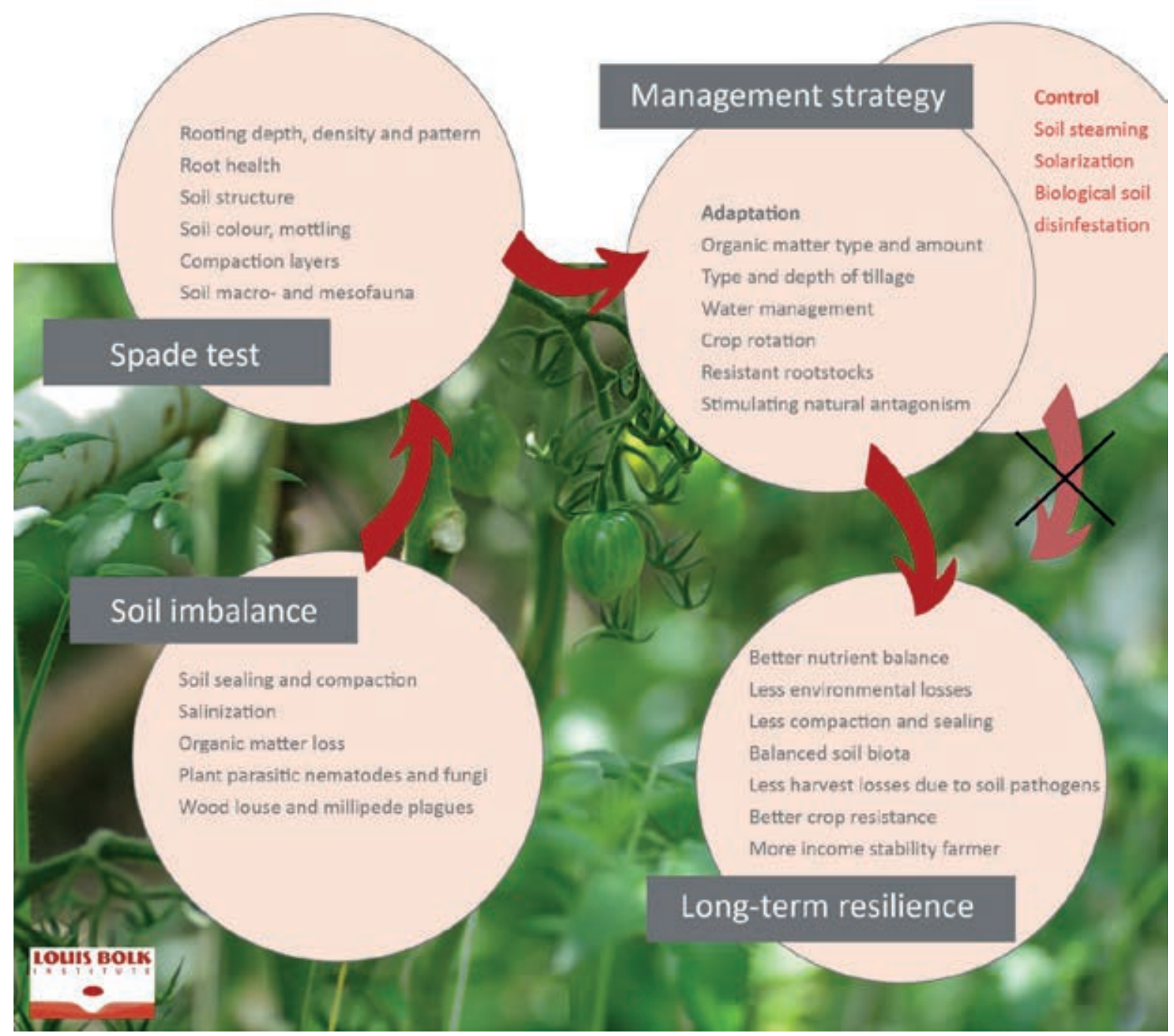

Figure 1.4 Sustainable soil management in organic greenhouse horticulture. Some management strategies are oriented towards adaptation, resulting in a more resilient system. Other strategies are focussed on control measures, which provide short-term solutions, but do not improve long-term resilience.

This makes organic greenhouse farming more risk oriented, and inclined towards management options based on control measures. Growers may even choose to use control measures like biological soil disinfestation, solarisation or soil steaming, when levels of soil-borne pathogens become so high, that severe production losses are likely. These measures reduce short-term risks, but the disturbances caused to soil biodiversity do not support long-time resilience.

In order to compensate for control measures which tend to decrease biodiversity and resilience, organic greenhouse growers apply a variety of strategies to support the natural capacity of the ecosystem to sustain production. High-quality compost is used to support soil biodiversity. Composts enriched with mycorrhiza or antagonistic fungi are applied in planting holes or at the nurseries. And although decomposition rates are low when compared to manure or side dressings, they form a strong source of nutrients over time due to the large amounts of compost applied. The next paragraphs will discuss the most important contributions which composts make to the various soil ecosystem functions. 

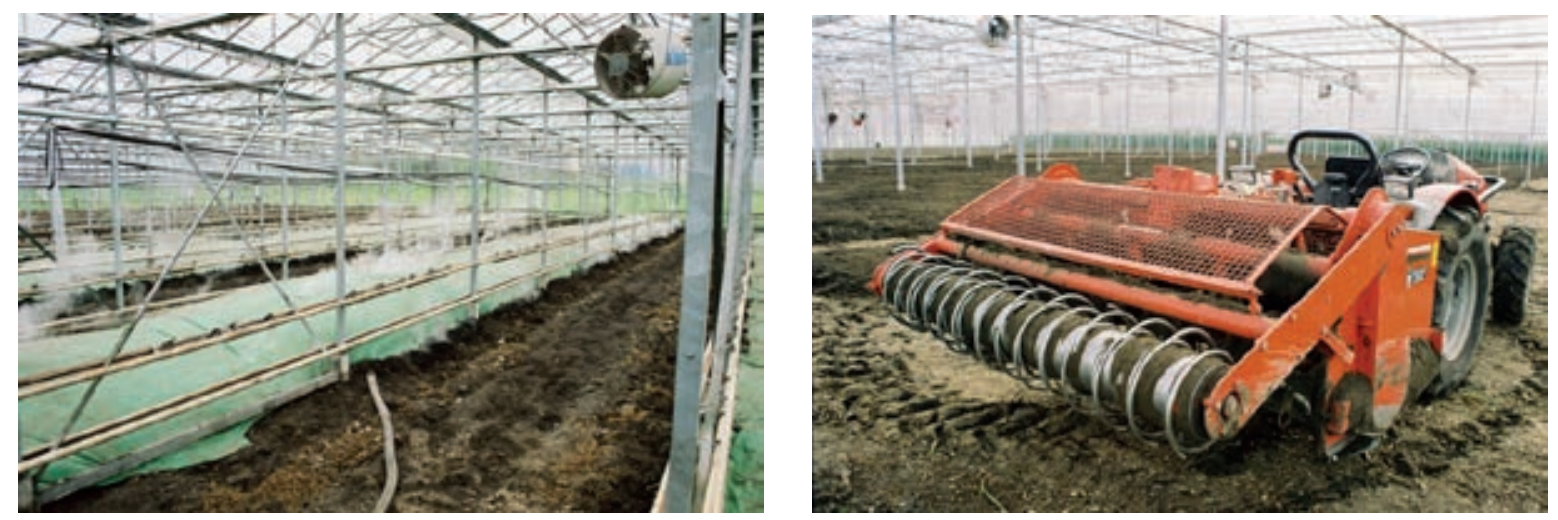

Figure 1.5 Management strategies in organic greenhouses involve sometimes control measures like soil steaming (left). Type, frequency and depth of tillage (right) can influence soil structure directly, but also indirectly by the effect on, for example, earthworms.

\subsection{Composts and soil ecosystem resilience}

Composts contribute to soil ecosystem resilience by nourishing the soil organisms that mediate the different functions of soils. Many functions of soils have relationships with specific soil organisms which help to sustain those functions. Although it may seem that functions like carrying capacity and resistance against sealing mainly depend on the mineral and textural characteristics of soil, these functions can also be enhanced by the activity of macrofauna (e.g. earthworms) and microflora (e.g. fungi, bacteria and algae). The majority of these functions would quickly deteriorate without a living soil. This chapter highlights the contributions which composts may make to various ecosystem functions of soils. These are direct through the addition of organic matter and nutrients to soil and, more importantly, indirect through the feeding of the organisms which support ecosystem functioning. The following major functions will be addressed below:

- Organic matter storage and transformation;

- Storage, transport and mineralization;

- Soil structure, aggregate stability, water storage and transport.

A very important aspect of soil ecosystem functions is the regulation of other soil biota, including soil-borne diseases. As disease suppressiveness of soils will be discussed in detail in Chapter 6, we will not expand on the subject here.

\subsubsection{Organic matter storage and transformation}

The living soil is at the basis of organic farming systems. Primary plant production will ultimately decline without a well-functioning soil that is rich in biodiversity. This is seen in all parts of the European Union, where an estimated 52 million hectares (more than $16 \%$ of the total land area) of soil are prone to some kind of degradation process ${ }^{10}$. In the Mediterranean area, desertification forms a serious threat, and about $1 / 3$ rd of the Mediterranean agricultural area is suffering from land degradation. Degradation also takes place in the young and most fertile soils of the Netherlands through compaction and loss of organic matter, caused mainly by intensified cultivation, narrowed down crop rotations, and the use of heavy machinery ${ }^{11}$. 
The presence of organic matter is of primary importance to soil biodiversity, as it is the primary energy source for soil micro-organisms, thus catalyzing and supporting the entire soil food web. As soil bacteria, fungi and protozoa decompose soil organic matter, they release inorganic nutrients that are necessary for plant growth. As earthworms break down soil organic matter, their casts line soil aggregates, and hold them together, providing a more stable soil structure. Burrows of earthworms foster both aeration and water infiltration. In the absence of a continuous input of fresh organic matter in the soil, the level of activity and diversity of soil organisms will ultimately decline. This could lead to a reduction of functions that soil organisms are able to carry out, and consequently a loss of resilience. The aboveground diversity of crops also influences the ability of the belowground microflora to convert organic amendments. Field experiments have shown that soils of fields with complex crop rotations decompose crop residues more rapidly than soils of fields with monocultures ${ }^{12}$.

The inherent amount of organic matter in a soil depends on both natural and human-induced factors. Important natural factors are climate and soil parent material. Decomposition rates of organic matter are a function of temperature and moisture content, and with every $10^{\circ} \mathrm{C}$ decrease in temperature, the average amount of organic matter increases with 2-3-fold ${ }^{10}$. Therefore, northern European soils naturally contain higher levels of organic matter than Mediterranean ones which typically contain up to $2 \%$ organic matter. Parent materials are also an important factor in the natural amount of organic matter available. Fluvisols on young, calcareous sea clay have strong mineralizing properties, which impede the increase in organic matter. More developed, and less calcareous, river clay soils have less strong mineralizing properties, and are able to develop higher organic matter contents over time ${ }^{13}$.
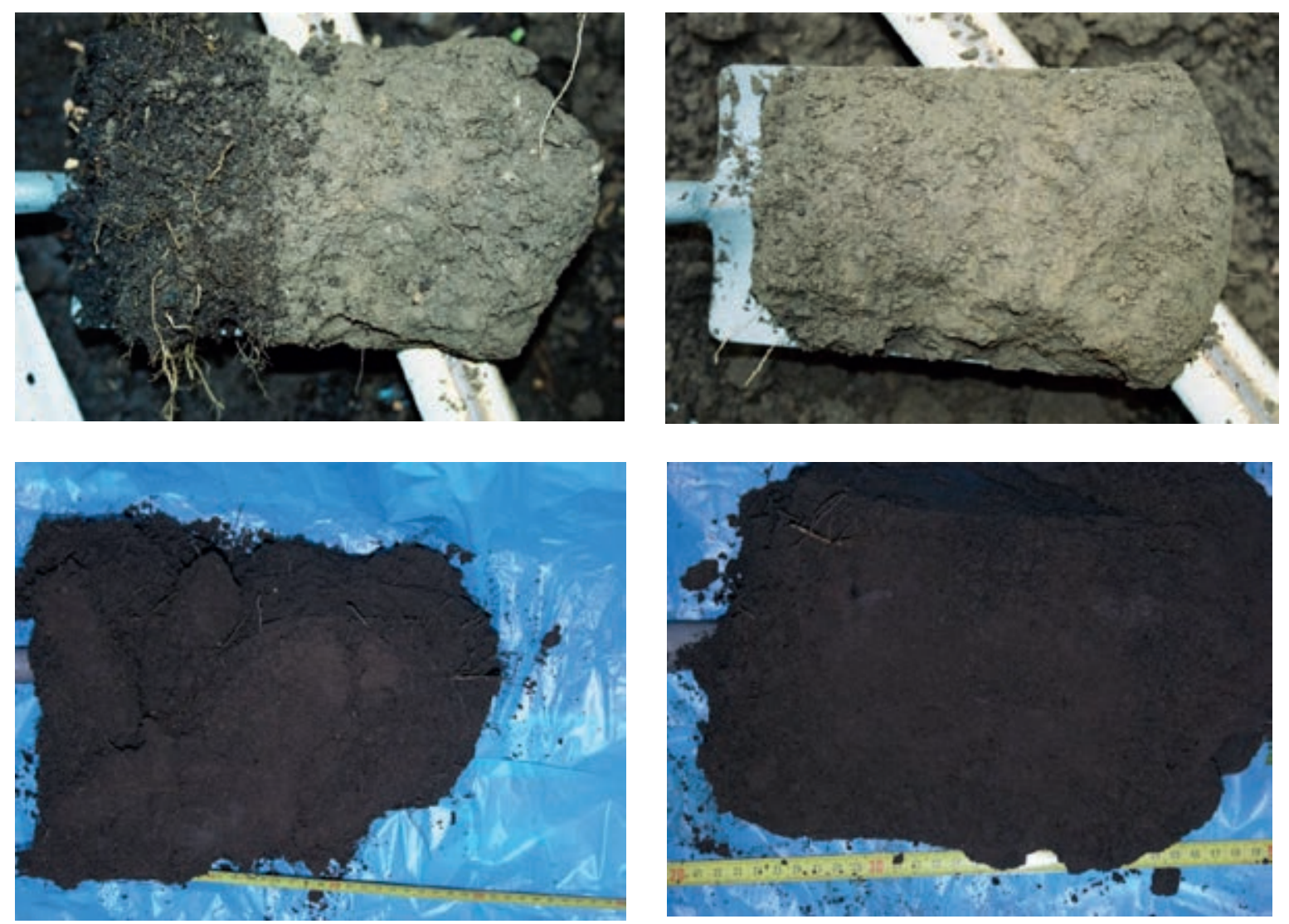

Figure 1.6 Soil profile of a sandy soil under organic greenhouse management in 2002 (top) and 2005 (bottom). Left: top $22 \mathrm{~cm}$, Right: lower $22 \mathrm{~cm}$. In 2002 there is a sharp demarcation between the different soil layers: the organic matter is confined to the upper $8 \mathrm{~cm}$ of soil, as are most of the roots. In 2005, after 3 seasons of ample compost application, the organic matter is homogeneously distributed through both soil layers. 
Human-induced factors are strongly responsible for the general decline of organic matter in soils. In intensive greenhouse horticulture, the application of green manures, stubbles and crop residues is generally limited. Some effective organic matter is added in the form of peat or compost in plant plugs, but soil amendments in the form of compost or manure are necessary to feed soil life and balance organic matter contents of the soil. The preferred type and amount of organic amendment depends on the specific soil characteristics.

About $3-4 \%$ organic matter will be decomposed annually in organic greenhouse soils in temperate regions. Decomposition rates will be higher on lighter, alkaline soils, and lower on heavier, acid soils. Decomposition rates will be much higher in a heated greenhouse or warmer climate than in a winter greenhouse or temperate region. In order to balance the decomposition of organic matter, fresh organic matter supply is necessary, through plant plugs, crop residues, compost or manure. The organic matter content that is desirable for a certain cropping system depends on soil type and climatic conditions. According to the European Soils Bureau Network ${ }^{10}$, soils are at a risk of degradation below organic matter contents of $1.7 \%$, as is commonly found in the majority of the Mediterranean countries. In temperate regions, organic matter contents of 3-5\% are desirable in intensive greenhouse cultivation
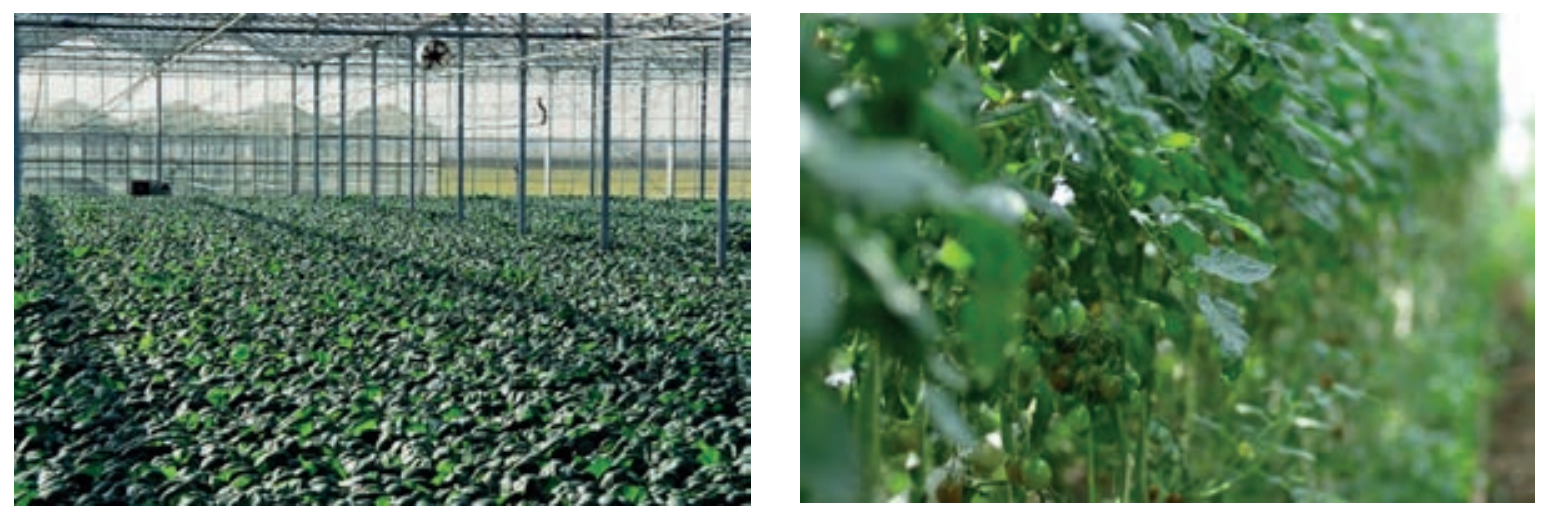

Figure 1.7 Greenhouses which are only heated in winter to keep them frost-free (left), have lower temperatures, and a slower organic matter break-down compared to year-round heated greenhouses (right).

In order to reach a balanced organic matter level in soil, a specific amount of manure or compost is necessary. In greenhouses with temperate climate, an annual application of 31 tonnes manure or compost per hectare is sufficient to maintain organic matter levels of $2-3 \%$, depending on soil type. Taking into account an additional 3 tonnes/ha of peat from plant plugs, soil organic matter contents of $4-6 \%$ may be possible. Higher levels of compost use (in the range of 100-200 tonnes/ha/yr) have increased average organic matter contents in Dutch greenhouses to $>8 \%$, but have unwanted by-effects, like nutrient losses, high EC levels, and plagues of wood louses and millipedes ${ }^{14}$. 


\subsubsection{Storage, transport and transformation of nutrients}

In organic greenhouse systems, composts are important sources of plant nutrients. Crop demands can be very high depending on the intensity of the cultivation system. Tomato yields of $>40 \mathrm{~kg} / \mathrm{m}^{2}$ are common in year-round organic greenhouse cultivation in The Netherlands, and crop demands easily surpass $800 \mathrm{~kg} \mathrm{~N} / \mathrm{ha} / \mathrm{yr}^{15}$. A large part of this nitrogen demand is delivered by mineralization of soil organic matter, which has been built up by regular application of compost. The nutrient contents of input materials for compost are very variable, as are the nutrient concentrations in the finished product. Woody materials generally contain far less nutrients than ligninpoor materials. Animal manures are mostly rich in $\mathrm{P}$ and $\mathrm{N}$, while grass or vegetable residues are rich in $\mathrm{N}$ and $\mathrm{K}$. Consequently, the nutrient contents in different composts can differ by a factor of 3 to 4 (see Table 1.1). This implies that it is crucial to analyze the nutrient content of a specific compost, in order to be able to calculate the nutrient balance, and not to use average values taken from the literature. Another important point to consider is the availability of the different nutrients for the plant. The composting process itself does not dramatically influence the nutrient composition of the material, except for $\mathrm{N}$. When the composting process is inappropriately managed, an important quantity of the mineralized $\mathrm{N}$ can be lost. Depending on compost maturity, only 0 to $10 \%$ of the $\mathrm{N}$ is available in the first year.

\section{Table 1.1}

Variability in chemical characteristics of composts in Switzerland (median values, with minimum and maximum values in parentheses). All feedstocks are source-separated ${ }^{16}$

\begin{tabular}{llll} 
Chemical characteristic & $\begin{array}{l}\text { Compost for agricultural } \\
\text { use }\end{array}$ & $\begin{array}{l}\text { Compost for horticultural } \\
\text { use }\end{array}$ & $\begin{array}{l}\text { Compost for greenhouse } \\
\text { cultivation and gardening }\end{array}$ \\
DM & $50.8(28.2-73.4)$ & $56.7(40.8-71.1)$ & $56.3(32.2-64.5)$ \\
\hline $\mathrm{OM}$ & $47.7(17.0-80.1)$ & $38.1(23.9-54.7)$ & $30.6(20.9-52.8)$ \\
\hline salt content & $862(361-1580)$ & $787(173-2657)$ & $660(328-1539)$ \\
\hline $\mathrm{pH}$ & $8.2(7.5-8.7)$ & $8.1(7.6-8.7)$ & $7.9(7.2-8.5)$ \\
\hline $\mathrm{N}$ & $16.6(8.7-26.0)$ & $14.6(9.2-27.6)$ & $15.1(8.6-25.2)$ \\
\hline $\mathrm{P}$ & $3.0(1.7-6.1)$ & $3.0(1.3-12.7)$ & $3.3(2.1-8.8)$ \\
\hline $\mathrm{K}$ & $12.0(5.7-25.2)$ & $11.6(2.2-20.7)$ & $10.7(5.5-27.8)$ \\
\hline $\mathrm{Mg}$ & $4.8(3.6-10.3)$ & $6.5(4.4-10.7)$ & $6.5(4.4-13.3)$ \\
\hline $\mathrm{Ca}$ & $53.1(24.0-83.7)$ & $64.0(35.0-91.5)$ & $44.5(29.5-69.4)$ \\
\hline $\mathrm{Fe}$ & $8.8(2.9-16.7)$ & $10.1(5.4-14.7)$ & $12.0(6.1-15.8)$
\end{tabular}

DM (dry matter) is given in \% of fresh material, OM (organic matter) in \% of DM, macronutrients ( $N, \mathrm{P}, \mathrm{K}, \mathrm{Mg}, \mathrm{Ca})$ in $\mathrm{g} / \mathrm{kg} \mathrm{DM}$, micronutrients $(\mathrm{Fe})$ in $\mathrm{mg} / \mathrm{kg} \mathrm{DM}$, salt contents in $\mathrm{mg} \mathrm{KCl} / 100 \mathrm{~g}$ fresh manure, $\mathrm{pH}$ is determined in $1: 2$ water extract.

Compost is a valuable source of organic matter, but it also contains many nutrients for crop production, including micronutrients. Proper use of compost is essential from both a production and an environmental point of view. Application rates that are too low may lead to nutrient deficiencies and low yields. Rates that are too high may foster nitrate leaching and phosphorus runoff.

Compost is used for both short- and long-term nutrient supply. Long-term experiments in Germany have shown that with regular application of compost (6-10 tonnes/ha/yr), the availability of $\mathrm{P}$ and $\mathrm{K}$ is $30-50 \%$ and $40-55 \%$, respectively. At the experimental station of the Federal Republic Baden-Württemberg, correlations were found between the rates of compost-applied $\mathrm{P}$ and $\mathrm{K}$ and the increase in soil available $\mathrm{P}$ and $\mathrm{K}$. The amount of available nutrients increased by $1.0 \mathrm{mg} \mathrm{P}_{2} \mathrm{O}_{5} / 100 \mathrm{~g}$ soil and $1.3 \mathrm{mg} \mathrm{K}_{2} \mathrm{O} / 100 \mathrm{~g}$ soil for each $100 \mathrm{~kg}$ of nutrient applied ${ }^{17}$. The estimation of $\mathrm{N}$ availability is more complex. 
Most of the $\mathrm{N}$ in compost is in the organic form, and essentially all of the $\mathrm{N}$ in mature compost is organic. Organic $\mathrm{N}$ is in simple forms (amino acids) available for plant uptake, but microorganisms mostly outcompete plant roots in the uptake of free amino acids, and decompose organic $\mathrm{N}$ to its inorganic forms ${ }^{18,19}$. Only a small part of $\mathrm{N}$ in compost is in inorganic forms. $\mathrm{NH}_{4}{ }^{+}$(ammonium) and $\mathrm{NH}_{3}$ (ammonia) are present in young composts. The $\mathrm{NH}_{4}-\mathrm{N}$ fraction is readily available for plant uptake. Other inorganic forms such as $\mathrm{NO}_{3}{ }^{-}$(nitrate) and $\mathrm{NO}_{2}$ (nitrite) are present in more mature composts, but their quantities are usually low. After the application of compost, the organic matter undergoes microbial transformations that release plant-available $\mathrm{N}$ over time. Denitrification, volatilization and leaching can result in $\mathrm{N}$ losses from the soil that reduce the amount of $\mathrm{N}$ that can be used by crops.

\subsubsection{Soil structure, aggregate stability, water storage and transport}

Soil structure basically describes the arrangement of particles and pores in soils. Soil structure can be viewed on different scales, and within these scales, different sized soil biota play a role in the creation, stabilization or degradation of soil aggregates ${ }^{20}$. The application of compost can have important effects on several aspects of soil structure. The addition of organic matter to soils in the form of compost can enhance the aggregate stability and hydraulic conductivity of soils. Amendments of between 10 and 30 ton/ha of municipal waste compost significantly increased the amount of water-stable aggregates, and enhanced microbial respiration, macroporosity and hydraulic conductivity. Microporosity was not affected ${ }^{21}$. The addition of both carbon-rich (C/N 108) and carbon-poorer (C/N 19.7) organic amendments to soils improved aggregate stability and influenced bacterial and fungal populations in soil. More specific research revealed that macro-aggregate formation was positively influenced by fungal activity but was not significantly affected by residue quality or bacterial activity ${ }^{22}$. Other experiments confirmed that there was no formation of macro-aggregates in the absence of fungal activity ${ }^{23}$. Experiments using compartments with combinations of mycorrhizal hyphae and/or roots, showed that both mycorrhizal hyphae and roots contribute individually to aggregate stability, and that their effects are cumulative when acting together. The experiments also suggested (but did not prove) a possible relationship between microbial numbers and aggregate stability ${ }^{24}$.

The single application of 10 ton/ha compost in orchards has been shown to alter the community structure of the microflora even after a three-year period. The most pronounced changes were seen in the fungal community structure, but the bacterial community structure was also significantly changed ${ }^{25}$. In this orchard, mycorrhizal fungi were specifically increased by application of compost. As mentioned in the above paragraph, fungi and specifically mycorrhizae play an important role in the stimulation of aggregate stability.

How strongly can the compost microflora affect the indigenous microflora of the soil? And how important is the compost microflora when applying compost to a sterilized (e.g. steamed) soil? To answer these questions, experiments have been designed in which combinations of sterilized and unsterilized soil and compost were used. The experiments used low and high amounts of grape compost: $0.5 \%$ and $5 \%(w / w)$, which is equivalent to the application of 12.5 and 125 ton/ha compost, respectively, in a $25 \mathrm{~cm}$ topsoil layer. In these experiments, it was seen that adding sterilized compost or non-sterilized compost to a non-sterilized soil gave only a weak difference between the treatments. However, adding non-sterilized compost or sterilized compost to a sterilized soil gave a much stronger difference between the treatments ${ }^{26}$. What changes occurred when soil was sterilized? 
Sterilization of soil caused a significant decrease in carbon mineralization and respiration. It also induced strong modifications of the genetic structure of the microbial community. The experiments also examined the shortterm and long-term (6 months) effects of compost application. Even a relatively low dose of compost (12.5 ton/ ha) in non-sterilized soil produced a weak but significant change in the microbial population structure in the first period after application. After 6 months however, this effect had disappeared, and the soil looked the same as if no compost had been applied. However, with a high dose of compost (125 ton/ha), after 6 months, the microbial community structure of the soil was still different. When comparing these effects of compost application to sterilized soil, a different picture emerges. Weak effects on the community structure of the soil were replaced by strong effects. These effects remained strong six months after application instead of only playing a role in the initial period after application. The authors suggested that most compost-borne micro-organisms are adapted to the compost environment (including $\mathrm{pH}$, temperature, organic matter quality and quantity), and cannot survive in or adapt to soil conditions: most compost-born microorganisms are outcompeted by soil-born microorganisms ${ }^{26}$. Important lessons can be drawn from these experiments regarding the application of compost after soil disinfestation: compost quality can determine strongly the microbial community in the soil for at least the following 6 months, and care should be taken of the quality of the applied compost.
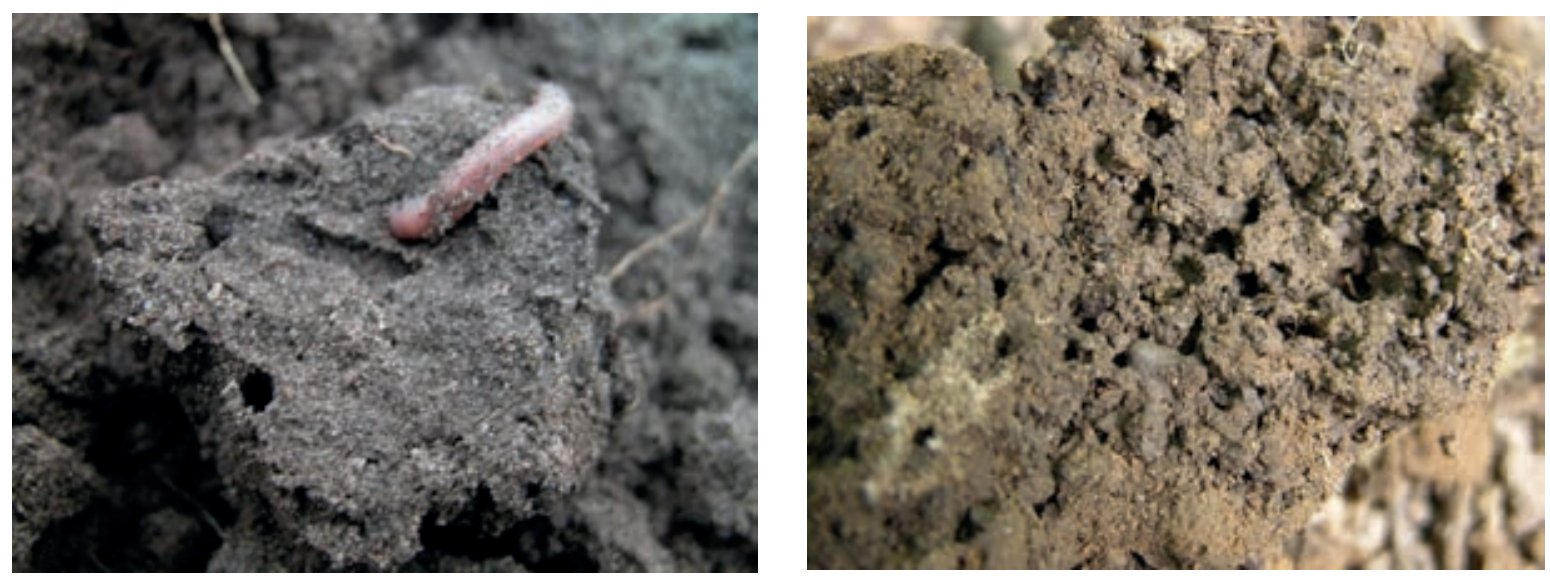

Figure 1.8 Earthworms play an important role in the formation of soil structure. Left: earthworm digging into a sharp-blocky structured soil. Right: earthworm burrows filled with worm-casts.

Earthworm populations play an important role in the formation of macropores (Figure 1.8). Deep-burrowing so-called anecic earthworm species make individual semi-permanent, mainly vertical burrows, while endogeic earthworm species produce extensive networks which are more horizontally orientated. Water infiltration might be enhanced 10 -fold or more, when a large earthworm population is present ${ }^{20}$. Epigeic species, like Lumbricus rubellus, are surface-dwelling, and survive mainly on raw humus. They contribute most to the formation of macropores in the top $10 \mathrm{~cm}$ of the topsoil, but in a soil without a litter layer, they can create burrows to at least $21 \mathrm{~cm}$ depth. Different endogeic species behave differently with regard to continuity of burrows in topsoil and subsoil, and with regard to the openness of the burrows to the soil surface. It has been suggested that ideal earthworm populations should consist of both deep-burrowing and topsoil-working species ${ }^{27}$. Urban compost amendments have been shown to increase natural populations of endogeic species up to 12-fold in clay loam, compared to plots receiving mineral fertilizer ${ }^{28}$.

\section{$1.4 \quad$ Visual soil assessment}

Many soil types are used for horticultural production. Each type of soil has its own characteristics, strengths and weaknesses. Knowing the particularities of a farmer's own soil is the first step in developing a sound soil management practice. The characteristics of the soil cannot only be judged by a chemical and/or biological soil analysis. A visual soil assessment in the field gives important information that is not revealed by laboratory analysis. Soil pits and spade analyses can both be helpful in visual soil assessments. 
In the soil pit, the vertical profile of the soil can be examined. The uppermost layer of topsoil is the area in which the plants root, and also the space where most chemical and biological activity occurs. The upper layer will often be darker in colour (but not always), as it contains most of the soil organic matter. Below the topsoil are one or more, lighter coloured soil layers. Although biologically less active, these layers are still important for plant growth, and roots may find water and nutrients in these deeper layers, while preventing nutrient leaching from the subsoil. In a soil pit, you may also observe layers that are obstructions to plant growth, either caused by human influence (plough pans) or by natural soil development (movement of clay, calcium, iron or humus into hard or smeary layers, that obstruct root growth). Soil structure, texture, rooting intensity, degree of aeration, and the presence and activity of soil organisms can be observed directly in the field, and give important information on soil management options.

The uppermost layers of soil can also be examined by a simple 'spade' analysis, which is less labour intensive than a profile pit (Figure 1.9). Depending on the variability in the field, a spade test can be carried out in more places: headlands or gateways for example, can have different problems than the rest of the field. (Box 1.1).

\section{Box 1.1 Spade analysis procedure}

\section{Remove with a spade an undisturbed spit of soil from the upper $\mathbf{3 0} \mathbf{~ c m}$ layer:}

- Choose an appropriate site in the field; during the growing season, you may choose a site close to the crop, in order to better examine root growth;

- Dig a small - $30 \mathrm{~cm}$ deep - pit into the soil;

- Loosen an undisturbed spit of approximately $10 \mathrm{~cm}$ thick at all sides by pushing the spade carefully in the soil at three sides;

- when pushing the spade in the third side, support the spit of soil while you remove it carefully from the pit, keeping it on the spade, and gently lay it on the ground.

\section{Visual spade assessment:}

- Examine if there are different soil layers visible;

- Examine the soil structural elements, by carefully breaking the clods apart. A knife or pocket lens may be helpful;

- Determine the volume of different structural elements within the soil layers;

- Determine the abundance and health of roots in the different layers. Notice abnormal growth (sudden change of direction, damaged or deteriorated roots, deformations caused by pathogens, root colour);

- Repeat the procedure for the 30-60 cm deep soil layer.

From a deeper soil pit, the following observations can be made:

- The distribution of different structural elements in the soil at different depths: angular blocky, sub-angular, granular or crumbly;

- The depth and number of roots: are they well-branched and numerous, or is rooting restricted, by restricted branching, or by growing sideways;

- The health of roots: colour (outside and inside), strength of the outer root layers, irregularities or deformations that indicate the presence of root pathogens, presence of nitrogen-fixing nodules (legumes);

- The presence of compact layers: plough pans, but also areas of clay, iron, calcium or organic matter accumulation;

- The activity of organisms in the soil: earthworm burrows and casts; the presence and abundance of earthworms and potworms (Enchytraeidae), springtails (Collembola), predatory mites, centipedes, millipedes and wood louses;

- The presence of crop residues and decaying roots in the soil layers;

- The presence of seashells or pieces of chalk;

- Degree of aeration and odour;

- The colour of the soil: layers and mottling (the presence of spots of a particular colour). Mottling may indicate that the soil is subject to waterlogging. 

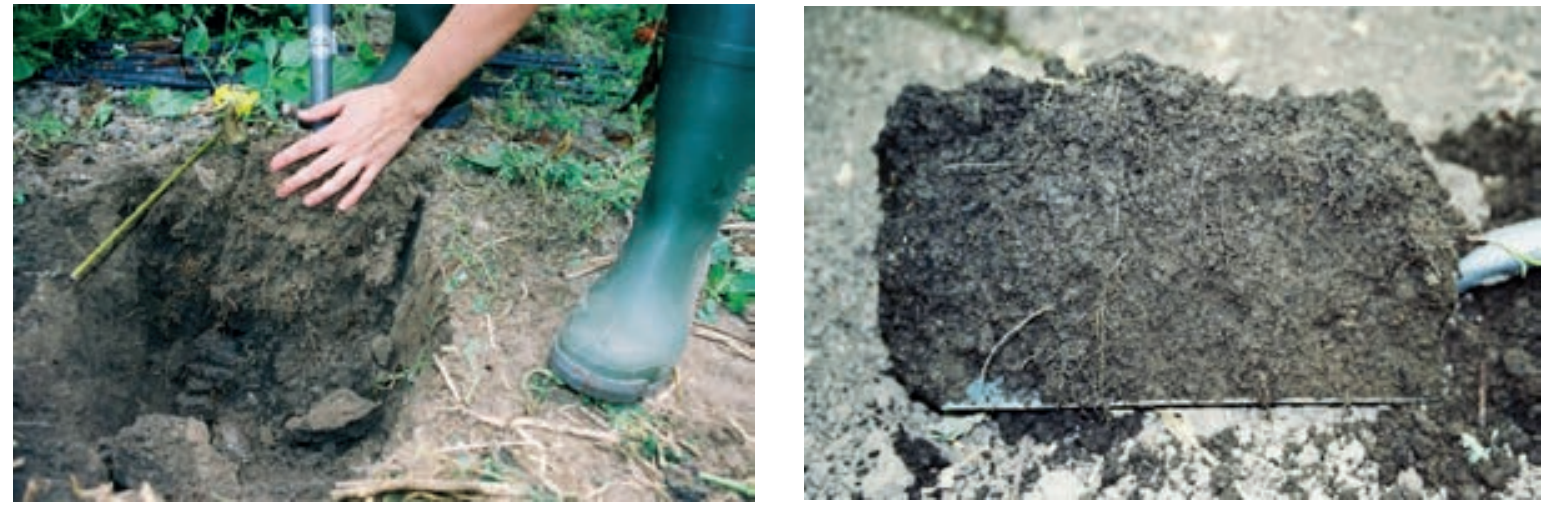

Figure 1.9 A simple spade analysis can provide a quick scan of the soil situation in the field. Left: support the spit of soil while removing it from the pit, so that it remains intact. The aim is to examine an undisturbed layer of soil: the layer at the front, which is not touched by the spade. Right: From the spade different observations can be made, like rooting intensity, continuity or discontinuity of soil layers, distribution of organic matter and presence of earthworms or angular structures in the deeper soil layers.

From the soil assessment in the field, the next step is to develop a soil management plan, including not only the type and amount of soil amendments, but also the frequency and depth of tillage, the use of crop rotation, rootstocks and water management. It may not be easy to determine which kind of manure or compost is most adequate in a certain situation, but based on the soil type and crop needs, some indications can be given. Both the development stage of the soil and the natural mineralization potential of the soil are important factors determining the choice of organic amendment. In a fast mineralizing, young calcareous soil, fast decomposing manure will provide even more nutrients to the plant, but will not support the long-term organic matter balance of the soil. Stable, composted manure or carbon-rich plant-based compost will in this case be more appropriate. However, when amendments with very high $\mathrm{C} / \mathrm{N}$ ratios are applied, the risk of $\mathrm{N}$ immobilization may be increased, even in fast mineralizing, young soils. On the other hand, when growing crops on slowly mineralizing, weathered and acid soils, a fresh manure or relatively young compost will be better able to activate soil life, and add to both bacterial and earthworm activity ${ }^{13}$. By observing carefully the year-to-year development of the soil, the effect of management practices on the specific soil type can be gradually learned and better adapted to the needs of both the soil type and cropping system.

\subsection{References}

1. IFOAM (2014).

The IFOAM Norms for Organic Production and Processing: Version 2014. Germany, 132p.

2. Holling C.S. (1973).

Resilience and Stability of Ecological Systems. Annual Review of Ecology and Systematics, 4(1): 1-23.

3. Cabell J.F., Oelofse M. (2012).

An Indicator Framework for Assessing Agroecosystem Resilience. Ecology and Society, 17(1).

4. Altieri M.A., Nicholls C.I., Henao A., Lana M.A. (2015).

Agroecology and the design of climate change-resilient farming systems. Agronomy for Sustainable

Development, 35(3): 869-890.

5. Loreau M., Naeem S., Inchausti P., Bengtsson J., Grime J.P., Hector A., et al. (2001).

Biodiversity and Ecosystem Functioning: Current Knowledge and Future Challenges. Science, 294(5543): 804-808.

6. Schmidt M.W.I., Torn M.S., Abiven S., Dittmar T., Guggenberger G., Janssens I.A., et al. (2011).

Persistence of soil organic matter as an ecosystem property. Nature, 478(7367): 49-56.

7. Loreau M. (2004).

Does functional redundancy exist? Oikos, 104(3): 606-611.

8. Cuijpers W., Koopmans C., Erisman J.-W. (2013).

Building on Resilience: Principles for Sustainable Agriculture, a Draft Framework. Driebergen, The Netherlands: Louis Bolk Institute, 47p. 
9. Ten Napel J., Bianchi F., Bestman M. (2006).

Utilising intrinsic robustness in agricultural production systems. Inventions for a sustainable development of agriculture. Working papers no 1: Transforum Agro \& Groen: 32-54.

10. European Soil Bureau Network (2005).

Soil Atlas of Europe. Luxembourg: European Commission.

11. Staps J.J.M., Ter Berg C., Van Vilsteren A., Lammerts van Bueren E.T., Jetten T.H. (2015).

Van bodemdilemma's naar integrale verduurzaming - Casus: Vruchtbaar Flevoland, van

bodemdegradatie en diepploegen naar integrale duurzame productie in Flevoland. Wetenschappelijke

Raad voor Integrale Duurzame Landbouw en Voeding, 58p.

12. McDaniel M.D., Grandy A.S., Tiemann L.K., Weintraub M.N. (2014).

Crop rotation complexity regulates the decomposition of high and low quality residues. Soil Biology and Biochemistry, 78: 243-254.

13. Bokhorst J., Ter Berg C. (eds) (2001).

Handboek Mest \& Compost: behandelen, beoordelen \& toepassen. Driebergen: Louis Bolk Institute, 292p.

14. Cuijpers W., Koopmans C. (2005).

Evenwicht in organische stof. In: Bodem \& bemesting: Gezonde bodem basis voor geslaagde teelt.

Biokas, p.22.

15. Cuijpers W., Koopmans C. (2005).

Principes van bemesting. In: Bodem \& bemesting: Gezonde bodem basis voor geslaagde teelt. Biokas, p.9.

16. Fuchs J.G., Bremer A., Mayer J., Smidt E., Schleiss K. (2008).

Influence of compost and digestates on plant growth and health: potentials and limits. In, Fuchs J.G., Kupper T., Tamm L., Schenk K. (eds). Compost and digestate: sustainability, benefits, impacts for the environment and for plant production. Proceedings of the international congress CODIS 2008, February 27-29, 2008; Solothurn, Switzerland: FiBL.

17. Kluge R. (2001).

Fertilisation effect of the $\mathrm{P}$ and $\mathrm{K}$ supply with composts. In: Amlinger F., Dreher P., Nortcliff $\mathrm{S}$., Weinfurtner K. (eds). Applying compost: benefits and needs. Seminar Proceedings, 22-23 November 2001; Brussels, Belgium.

18. Ge T., Song S., Roberts P., Jones D.L., Huang D., Iwasaki K. (2009). Amino acids as a nitrogen source for tomato seedlings: The use of dual-labeled $(13 \mathrm{C}, 15 \mathrm{~N})$ glycine to test for direct uptake by tomato seedlings. Environmental and Experimental Botany, 66(3): 357-361.

19. Owen A.G., Jones D.L. (2001).

Competition for amino acids between wheat roots and rhizosphere microorganisms and the role of amino acids in plant $\mathrm{N}$ acquisition. Soil Biology and Biochemistry, 33(4-5): 651-657.

20. Oades J.M. (1993).

International Workshop on Methods of Research on Soil Structure/Soil Biota Interrelationships. The role of biology in the formation, stabilization and degradation of soil structure. Geoderma, 56(1): 377-400.

21. Yazdanpanah N., Mahmoodabadi M., Cerdà A. (2016).

The impact of organic amendments on soil hydrology, structure and microbial respiration in semiarid lands. Geoderma, 266: 58-65.

22. Bossuyt H., Denef K., Six J., Frey S.D., Merckx R., Paustian K. (2001).

Influence of microbial populations and residue quality on aggregate stability. Applied Soil Ecology, 16(3): 195-208.

23. Denef K., Six J., Bossuyt H., Frey S.D., Elliott E.T., Merckx R., et al. (2001).

Influence of dry-wet cycles on the interrelationship between aggregate, particulate organic matter, and microbial community dynamics. Soil Biology and Biochemistry, 33(12-13): 1599-1611.

24. Andrade G., Mihara K.L., Linderman R.G., Bethlenfalvay G.J. (1998).

Soil aggregation status and rhizobacteria in the mycorrhizosphere. Plant and Soil, 202(1): 89-96.

25. Abujabhah I.S., Bound S.A., Doyle R., Bowman J.P. (2016).

Effects of biochar and compost amendments on soil physico-chemical properties and the total community within a temperate agricultural soil. Applied Soil Ecology, 98: 243-253.

26. Saison C., Degrange V., Oliver R., Millard P., Commeaux C., Montange D., et al. (2006).

Alteration and resilience of the soil microbial community following compost amendment: effects of compost level and compost-borne microbial community. Environmental Microbiology, 8(2): 247-257. 
27. Francis G.S., Fraser P.M. (1998).

The effects of three earthworm species on soil macroporosity and hydraulic conductivity. Applied Soil Ecology, 10(1-2): 11-19.

28. Lapied E., Nahmani J., Rousseau G.X. (2009).

Influence of texture and amendments on soil properties and earthworm communities. Applied Soil Ecology, 43(2-3): 241-249. 
28 I Handbook for Composting and Compost Use in Organic Horticulture 


\title{
2 Compost types, feedstocks and composting methods
}

\author{
Jacques G. Fuchs and Willemijn J.M. Cuijpers
}

In short:

- Compost types are characterized by feedstocks, composting processes and compost maturity.

- Feedstocks for composting differ greatly in carbon and nutrient contents, moisture and salinity.

- Mixing different feedstocks is necessary to obtain a good compost quality. Not only is the $\mathrm{C} / \mathrm{N}$ ratio of the starting materials important to consider but also the C/P and N/P ratios.

- Different feedstocks also result in different structured starting mixes and different moisture contents, which is important for good aeration during the composting process.

- A wide range of composting methods has been developed. A broad division can be made between the level of technology used, e.g. with or without forced aeration, and if the system is open or closed to the environment.

- The degree of maturity is an important characteristic of compost, which is determined by the management and duration of the curing phase.

\section{$2.1 \quad$ Compost types}

The type of soil, the aim of the compost application and the availability of organic materials will influence the choices of a grower for the most suitable forms of organic amendments. There are limited possibilities for greenhouse growers to apply green manures or crop rotations with soil-nurturing and deep-rooting crops like grains, so the grower is dependent on the use of a variety of manure and compost types in order to sustain the organic matter content of the soil. The grower may needs to make important choices between the use of fresh manure, compost and digestate. Compost is the result of an aerobic transformation process, while digestate is the result of an anaerobic process. The differences between compost and digestate are discussed in Chapter 7 .
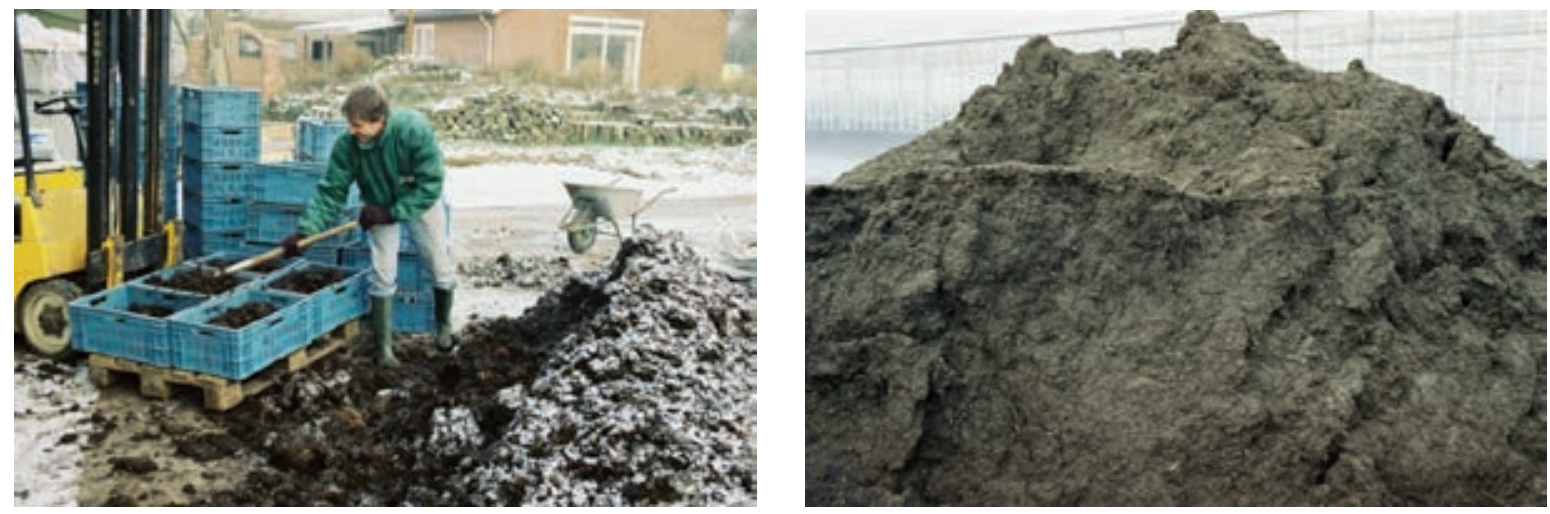

Figure 2.1 Manure (left) and compost (right) used for on-farm experiments on the effects of different organic amendments on soil structure and sealing.

Different types of compost and manure have different chemical and biological properties. They will add different qualities of organic matter when mixed with the soil. Compost generally has more the character of a soil-feeding amendment, while fresh or slightly composted manure also has an important plant-feeding component. 
In addition the fresh organic matter of manure will stimulate soil life in a different way when compared to organic materials that have been composted. Sometimes uncomposted crop residues are used, as in the use of lignin-rich crop-residues like wheat straw (Figure 2.2) to improve disease suppressiveness against soilborne diseases. The most important constraint to the use of fresh instead of composted crop residues is the possible contamination with plant pathogens. There are no general rules that determine which kind of organic amendment to use. The biological, chemical and physical characteristics of the soil and the grower's experience of the soil determine the most appropriate choice. The regional availability of compost or manure may also play an important role in the final decision.
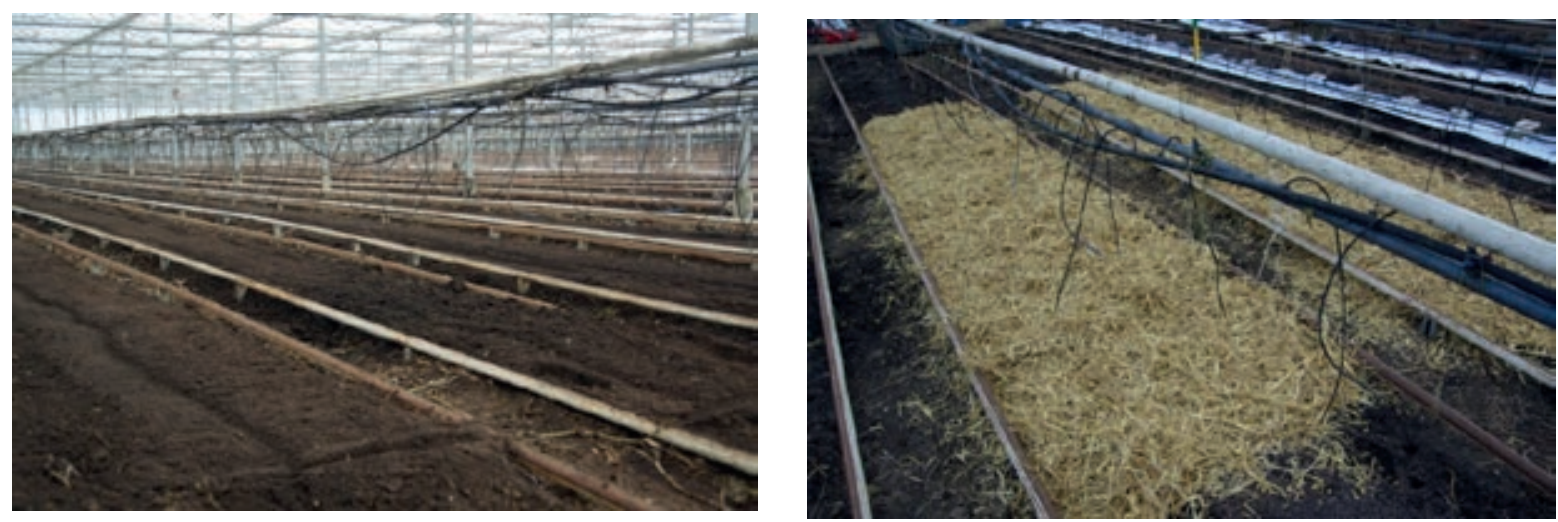

Figure 2.2 Application of compost in organic greenhouse (left) and application of wheat straw in experimental plots (right). Straw has been traditionally used in cucumber cultivation to enhance soil temperatures in planting beds. It is experimentally used to stimulate lignin-degrading organisms in soil, and improve disease suppressiveness. As the materials are used on a very rich soil, the risk of nitrogen immobilization is limited.

Several types of composts are available for organic greenhouse growers. The most common are traditional composts made of a combination of manure and plant residues. In this mix, the manure provides most of the nutrients, including nitrogen $(\mathrm{N})$, phosphorus $(\mathrm{P})$ and potassium $(\mathrm{K})$. The abundant presence of microorganisms in manure also enables the onset of a fast decomposition process, once exposed to sufficient levels of moisture and oxygen. The plant material is much better aerated than the manure and thereby helps to enable air penetration (forced or by passive diffusion) to all parts of the compost pile, including its core. Other types of feedstocks are source-separated municipal waste (the organic fraction) and spent mushroom compost. Some feedstocks, like sewage sludge, are not allowed in organic agriculture. Input materials will influence not only the nutrient contents of the finished compost but also its salinity. They also determine, together with the process management, the stable humus content of the final product and the composition of the microbial population. In the following paragraphs, the main factors which distinguish between compost types are discussed: feedstocks, processes and maturity. Table 2.1 shows the influence of these three factors on specific compost characteristics. 
Table 2.1

Relative importance of feedstocks, process management and maturity on specific compost characteristics.

\begin{tabular}{llll} 
Compost characteristics & Feedstocks & Process management & Maturity \\
Total nutrient content & +++ & + & - \\
\hline Available nitrogen & ++ & +++ & +++ \\
\hline Salinity & +++ & $(+)$ & + \\
\hline $\mathrm{pH}$ & ++ & + & +++ \\
\hline Humus content / water & ++ & + & +++ \\
extract colour & ++ & + & +++ \\
\hline Stable humin content & + & ++ & +++ \\
\hline Phytotoxicity & + & +++ & ++ \\
\hline Disease suppressive & ++ & & +
\end{tabular}

- almost no influence; + little influence; ++ moderate influence; +++ strong influence

\subsection{Compost feedstocks}

Different feedstocks will add different amounts of carbon (energy) and nutrients to the compost. When composting on-farm, the availability of manure will influence the characteristics of the resulting compost. Some basic knowledge of manure types can be helpful in designing the right starting mixture for the composting process. The composition of manure is highly variable, according to animal type, animal diet, type of housing, and the amount and type of litter, and (spilling) water used. Storage conditions and the length of storage are important factors in the amount of gaseous losses. Treatment measures such as rotating the manure heap, aeration and the use of additives will also influence the loss of organic matter and nutrients. Analysis of solid and liquid manures from cattle and solid manure from pigs on German organic farms has shown that minimum and maximum values from these farms were often wider apart than corresponding ranges of conventional farmyard manures, and that mean nutrient values tended to be in the lower to mid-range of conventional manures (Table 2.2). Manure from deep-litter stables was found to be particularly rich in potassium, as this type of manure also contains the urine ${ }^{1}$.

Manure from ruminants (cattle, goats, sheep) differs essentially from manure from non-ruminants (pigs and poultry). Ruminants have a four-compartment stomach, and are able to digest structured and cellulose-rich plant materials, with the aid of fermentation by anaerobic bacteria that reside inside the rumen. The nutrient ratio in the manure is comparable with the nutrient ratio of many crops. The ratio between protein and energy-yielding nutrition in the ruminant diet can significantly influence the nutrient contents of the manure. A low protein diet will result in lower total $\mathrm{N}$ contents of the manure, and in higher amounts of organic $\mathrm{N}^{2}$. Research on dairy farms on mineral soils in the Netherlands has shown that during the period 1997-2010, N-total, Total Ammoniacal Nitrogen (TAN) and $\mathrm{K}$ contents of dairy cattle manure significantly decreased, probably as a result of decreasing fertilizer inputs on the land. On the other hand, P and $\mathrm{Mg}$ contents in manure remained stable ${ }^{3}$. 


\section{Table 2.2}

Variability in chemical parameters and nutrient contents (mean, minimum and maximum) of solid organic cattle manure ( $n=96)$, solid pig manure $(n=18)$ and liquid cattle manure $(n=13)$, compared with conventional reference values (adapted from ${ }^{1}$ ).

\begin{tabular}{lllllll} 
Parameters & \multicolumn{2}{l}{ Solid cattle manure } & Solid pig manure & \multicolumn{2}{l}{ Liquid cattle manure } \\
\cline { 2 - 6 } & organic & reference & organic & reference & organic & reference \\
$\mathrm{DM}$ & $21.8(10.4-39.3)$ & $19.0-25.0$ & $23.4(13.6-38.4)$ & $20.0-25.0$ & $6.4(2.4-13.8)$ & $4.4-15.0$ \\
\hline $\mathrm{OM}$ & $14.7(8.5-20.8)$ & $15.0-20.3$ & & & & \\
\hline $\mathrm{C} / \mathrm{N}$ & $16.3(8.4-30.7)$ & 14.0 & $12.5(9.0-19.4)$ & 10.0 & $10.8(6.3-18.1)$ \\
\hline $\mathrm{pH}$ & $8.4(5.9-9.2)$ & & $8.2(7.1-8.9)$ & & $7.3(6.9-7.5)$ & \\
\hline $\mathrm{N}-$ total & $0.49(0.22-1.02)$ & $0.40-0.60$ & $0.61(0.40-1.00)$ & $0.55-1.1$ & $0.22(0.11-0.35)$ & $0.20-0.69$ \\
\hline $\mathrm{P}_{2} \mathrm{O}_{5}$ & $0.28(0.05-0.66)$ & $0.20-0.40$ & $0.57(0.21-1.08)$ & $0.75-0.85$ & $0.09(0.04-0.21)$ & $0.09-0.36$ \\
\hline $\mathrm{K}_{2} \mathrm{O}$ & $0.80(0.07-2.30)$ & $0.37-0.70$ & $0.61(0.31-1.39)$ & $0.50-0.80$ & $0.30(0.17-0.48)$ & $0.28-0.90$ \\
\hline $\mathrm{MgO}$ & $0.13(0.01-0.33)$ & $0.10-0.19$ & $0.16(0.08-0.26)$ & $0.20-0.26$ & $0.05(0.02-0.11)$ & $0.04-0.11$ \\
\hline $\mathrm{CaO}$ & $0.26(0.01-0.79)$ & $0.41-0.64$ & $0.27(0.08-0.56)$ & $0.40-0.84$ & $0.11(0.04-0.20)$ & $0.13-0.39$ \\
\hline
\end{tabular}

Nutrient contents, DM (dry matter) and OM (organic matter) are given in \% of fresh weight.
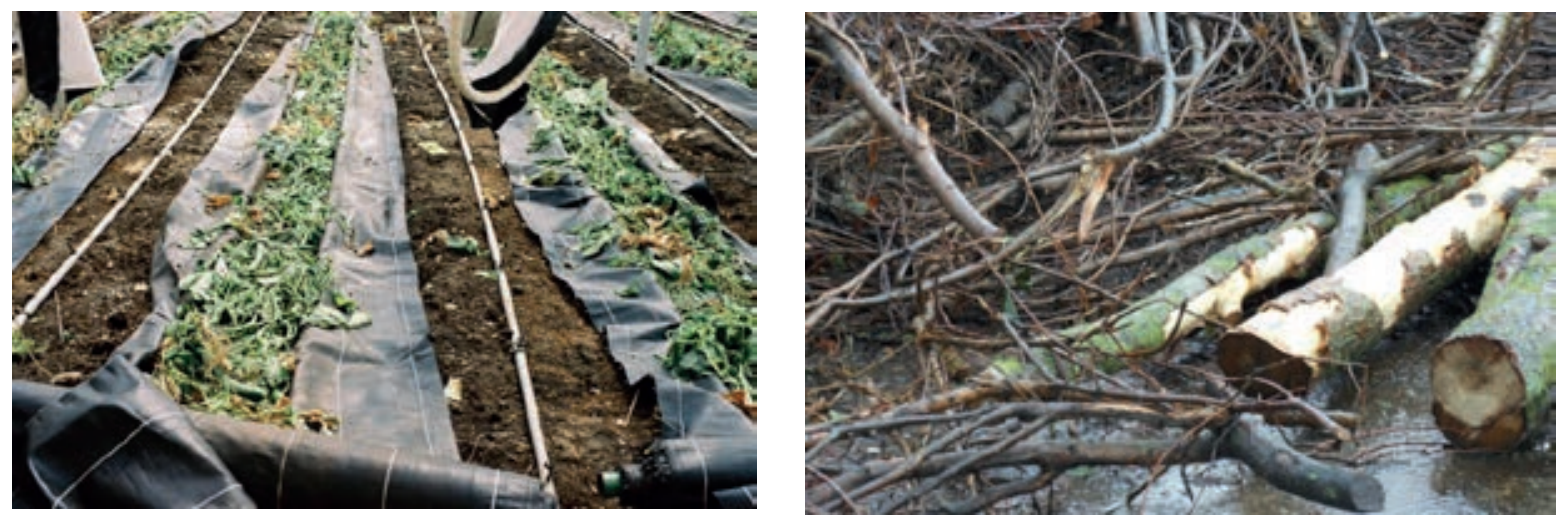

Figure 2.3 Bulking agents which can be used when composting manure are crop residues (left: cucumber) or wood (right). When crop residues are used, sufficiently high temperatures have to be reached during composting, for a long enough duration to avoid survival of plant pathogens.

Non-ruminants convert a diet rich in grains, into a relatively nutrient-rich manure, with high amounts of $\mathrm{N}$ compared to other nutrients ${ }^{2}$. The N/P and C/P ratios of these types of manure are a particular constraint to their application as organic fertilizers. Experiments in which chicken manure has been composted together with carbon-rich feedstocks (42.5 vol\% bark), produced high quality organic amendments in terms of organic matter content, C/P ratio, C/N ratio and stability. The upper limit for the use of fresh chicken manure in small-scale onfarm windrow composting has been indicated to be 10 vol\%. Nutrient losses become too high above this value and the N/P ratio of the obtained fertilizer becomes too low. Composting of chicken litter (with an initial C/N ratio of 14-15) without addition of bulking agents, can lead to $\mathrm{N}$ losses of as much as $58 \%$ of the initial $\mathrm{N}^{4}$. Table 2.3 gives an overview of the nutrient contents in different feedstocks ${ }^{5}$. 


\section{Table 2.3}

The composition of feedstocks used in combination with chicken manure, in order to improve the quality as an organic amendment for soil, notably the $C / P$ and N/P ratios (adapted from ${ }^{5}$ ).

\begin{tabular}{lrrrrrrrrr} 
Feedstock & DM & OM & C/N & N/P & Ntot & P & $K$ & Ca & Mg \\
wheat straw & 92.4 & 95.1 & 117 & 7.6 & 4.5 & 0.6 & 2.6 & 2.9 & 0.7 \\
\hline grass hay & 63.5 & 92.4 & 51 & 5.1 & 10.0 & 2.0 & 17.6 & 4 & 1.2 \\
\hline poplar bark & 46.5 & 90.3 & 58 & 7.1 & 8.8 & 1.3 & 6.6 & 26.6 & 1.7 \\
\hline willow wood chips & 46.9 & 96.7 & 85 & 6.8 & 6.4 & 0.9 & 2.8 & 7.5 & 0.6 \\
\hline chicken manure & 62.7 & 42.8 & 8.3 & 1.9 & 29.0 & 15.5 & 21.7 & 73.9 & 4.9 \\
\hline grass clippings & 8.9 & 88.2 & 24 & 4.9 & 20.3 & 4.1 & 35.4 & 4.8 & 1.7 \\
\hline
\end{tabular}

Values are averages of 4 samples per feedstock. OM organic matter, DM dry matter, Ntot total nitrogen. DM is given in \% of the fresh product, OM in \% of DM. Nutrient concentrations are given in $\mathrm{g} / \mathrm{kg} \mathrm{DM}$.

Composting will have an effect on the quality of the manure. Composted cattle manure will be more stable than fresh or only slightly composted manure. Composted manures will also add more effective organic matter to the soil, compared to the original material. On the other hand, they will provide less food for soil life, as part of the carbon (energy) source has already been utilized by bacteria and fungi during the composting process. Composted cattle manure has a stronger alkaline effect on amended soils compared to fresh manure. The alkaline effect of cattle manure is attributed to buffering by bicarbonates and organic acids in cattle manure ${ }^{6}$. Sheep manure from ewes that are kept in sheds during the lambing season, is generally dry, and rich in straw. It is very suitable for composting, although mixing with carbon-rich materials may be necessary to prevent nitrogen loss. Goat manure is also relatively dry and straw-rich. It may contain more $\mathrm{N}$ than cattle manure, and can be mixed with carbon-rich material during composting ${ }^{2}$.

Not all fresh manures can be directly composted i.e. without the addition of bulking agents and carbon rich materials to increase the $\mathrm{C} / \mathrm{N}$ ratio and provide sufficient oxygen transport during the composting process. Manure from laying hens is very nutrient rich, and is characterized by rapid mineralisation, and a low amount of effective organic matter. It is therefore mainly valued as a direct source of plant feeding manure, and often used in dried, pelleted form during the growing season. Composting this type of manure with the addition of carbon-rich materials increases the soil-building quality of the manure. Solid pig manure can be very variable in composition, depending on the amount of straw and the diet. Depending on the amount of straw, adding carbonrich materials may be necessary for composting. Composting pig manure is preferred as it will increase the amount of organically bound nitrogen, and provide a more diverse source of micro-organisms ${ }^{2}$.

\subsection{Compost starting mixes}

In the previous paragraph we discussed how the input materials influence the characteristics of the produced compost. The choice of input materials also influences the composting process, and the resulting compost quality. To obtain a high compost quality, it is first of all important that the organic input materials are of high quality. They should be free from pollutants and other undesirable materials like plastics, metal or glass. High-quality compost can only be produced with source separated organic materials. To guarantee a good composting process, the starting mixture has to have an adequate $\mathrm{C} / \mathrm{N}$ ratio between 25 and 35 . The mixture should also have an appropriate structure to allow optimal oxygenation of the material without too much loss of temperature. The higher the windrow is, the coarser the mixture has to be. 
Lignin-rich material can be stored for a long time without loss of nutrients. In contrast, $\mathrm{N}$-rich material has to be treated as soon as possible to avoid a decline of quality through gaseous emissions and odours. The supply of organic input materials to compost plants often varies significantly during the year. Lignin-rich materials are mostly supplied in winter while high quantities of N-rich materials are supplied in spring and summer. For this reason, supply and storage of input materials should be balanced throughout the year. Adequate amounts of lignin-rich materials should be stored, in order to be able to compose an appropriate starting mixture when high supplies of $\mathrm{N}$-rich materials become available.

A useful rule-of-thumb to prepare a starting mix is:

- $1 / 3$ rough wood (e.g. shredded wood, saving rest material from compost, snipped bark).

- 1/3 medium-fine, fibrous material (e.g. shredded branches, wood fibers, straw, foliage, switch grass, reed).

- $1 / 3$ fine materials (kitchen waste, grass clippings, manure, vegetable waste).

To improve the composting process, clays such as zeolites (5-10 kg/m $\mathrm{m}^{3}$ starting mixture) or clay-rich soil (3-5\% of the starting mixture) can be added. These materials buffer the composting process, diminish odor emissions and improve the formation of stable crumbs during the curing phase of the compost. The technical preparation of the input materials also plays an important role in the decomposition of the material. This is especially important for wood. If wood is chopped into chips, microbial colonisation is inefficient and the capacity of the wood as a structure-adding material to improve the aeration of the windrow is low. If the wood is correctly shredded and well de-fibered, microorganisms have good access to the material and the aeration of the windrow is highly improved (Figure 2.4). Finally, it is essential that the starting mixture contains sufficient moisture to allow the microorganisms to become active.
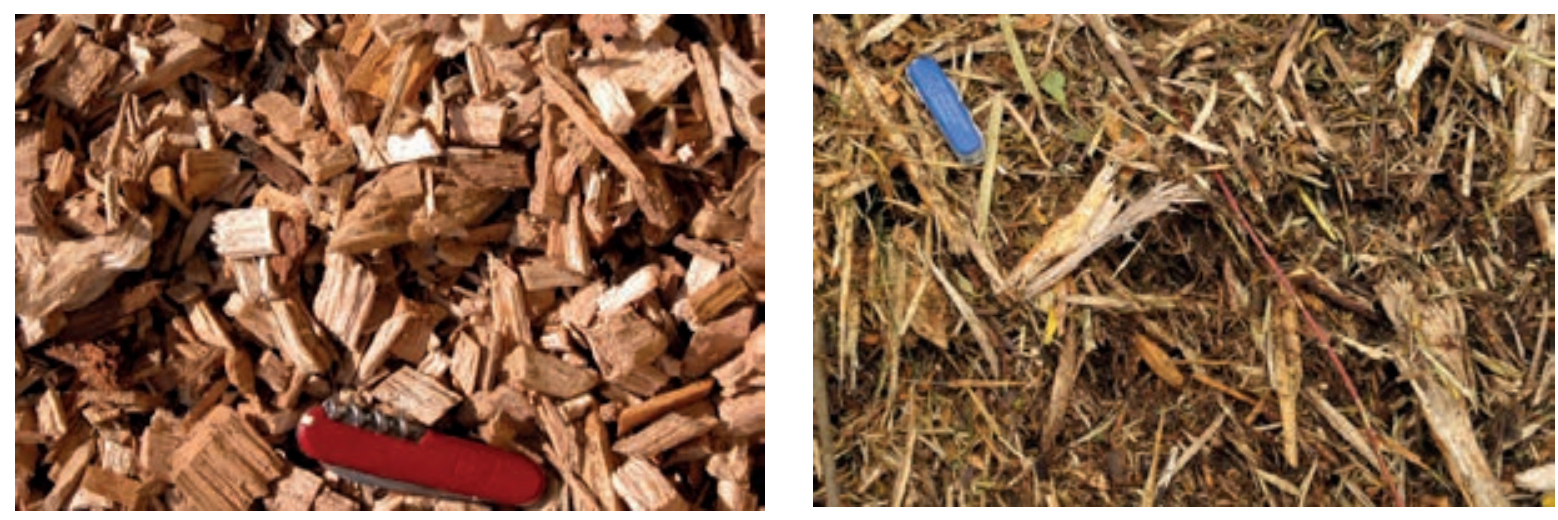

Figure 2.4 Wood chips (left) cannot be efficiently decomposed by compost microorganisms, whereas defibered wood (right) can. The use of defibered wood results in a better structure within the windrows and allows for a better aeration. 
Table 2.4

The $C / N$ ratio of different organic materials is important in designing a good starting mixture.

\begin{tabular}{llll} 
Organic material & $\mathrm{C} / \mathrm{N}$ & Organic material & $\mathrm{C} / \mathrm{N}$ \\
Urine & 0.8 & Kitchen organic waste & $15-25$ \\
\hline Feathers & $4-5$ & Ideal C:N of starting mixture & $30-35$ \\
\hline Pig bristles & 5 & Rumen* & $25-30$ \\
\hline Chicken manure & $8-10$ & Garden waste & $20-35$ \\
\hline Food waste & $14-17$ & Coffee grounds & $20-30$ \\
\hline Grass clippings & $9-25$ & Fruit waste & $25-40$ \\
\hline Hay & $15-25$ & Nut shells & 35 \\
\hline Mature compost & $12-15$ & Tree leaves & $40-70$ \\
\hline Young compost & $15-18$ & Straw & $50-100$ \\
\hline Cow manure & $15-20$ & Wood (sawdust) & $200-500$
\end{tabular}

*the rumen content of slaughtered cattle 

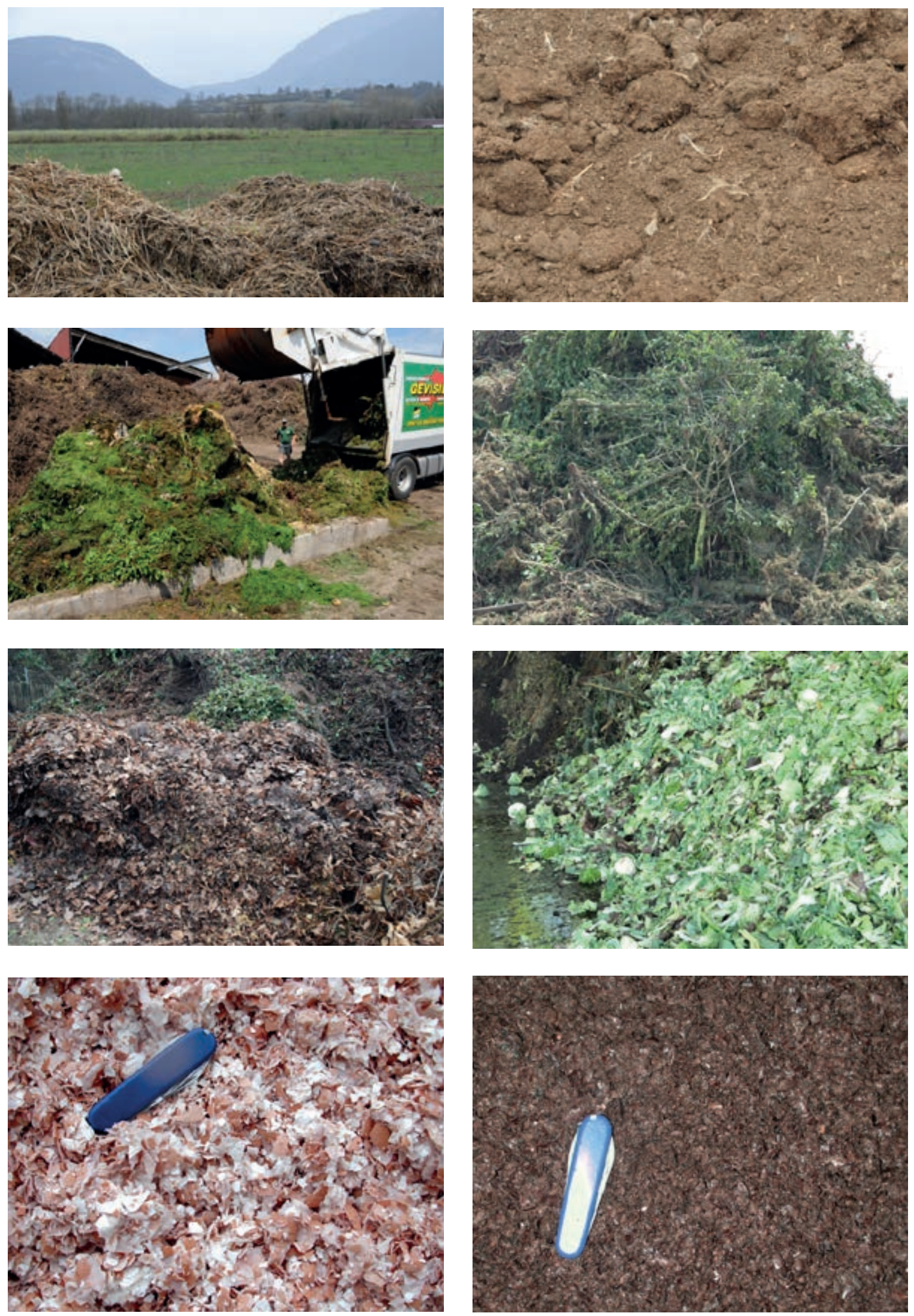

Figure 2.5 Example of input materials for compost production. From left to right, top to bottom: manure, chicken manure, grass; garden waste, leaves, vegetables waste, eggshells, cocoa husks. 


\section{$2.4 \quad$ Composting methods}

Many composting methods have been developed over time. In the Netherlands, there has been a long history of compost use. Cities were already composting refuse and selling it to farmers before the introduction of synthetic fertilizers around 1900. In 1929 the city of The Hague started operating a composting plant using a modified version of the so-called Indore process in which large windrows were used ${ }^{7}$. The Indore composting system was developed in India by Sir Albert Howard (1873-1947) during the 1920s. The method uses layered mixtures of high $\mathrm{C} / \mathrm{N}$ feedstocks like plant leaves with low $\mathrm{C} / \mathrm{N}$ feedstocks like animal manure in an approximately 3:1 ratio. Thick layers of crop residues are covered by thin layers of manure, and these are covered by very thin layers of topsoil and limestone. The waste is put into pits or trenches, or piled on open ground to a height of 1.5-1.8 m, and manually turned at 6-8 week intervals. The total composting time of the Indore method is 4-6 months ${ }^{7,8}$. In 1932 the Dutch government supported the establishment of a non-profit organization, which was entrusted with the composting of municipal refuse in Wijster: the VAM (Vuilafvoer Maatschappij) or Refuse Disposal Company. The manual process of the Indore method was adapted, and mechanical processes were introduced in some of the composting steps.

In the 1930 s and 1940 s mechanical processes were further developed, mainly involving initial shredding and mixing of materials to facilitate composting. Giovanni Beccari developed and patented a new composting method in the 1920s in Florence, Italy. The Beccari method starts with anaerobic fermentation, and has a final stage in which decomposition takes place under partially aerobic conditions. Another system was developed in the early 1930s in Copenhagen. Partial decomposition of the feedstocks was obtained by pre-treatment of refuse in a rotating silo or drum. The materials were mixed and grounded before they were composted using the Indore method ${ }^{7}$. In the 1940s Eric Eweson developed a rotary drum composting system in the US. Influenced by Sir Albert Howard, he designed a system in which the compost material is anaerobically fermented in a large rotary drum, for 3-6 days, followed by windrow composting. This system has been very successful, and is still being applied ${ }^{8}$.
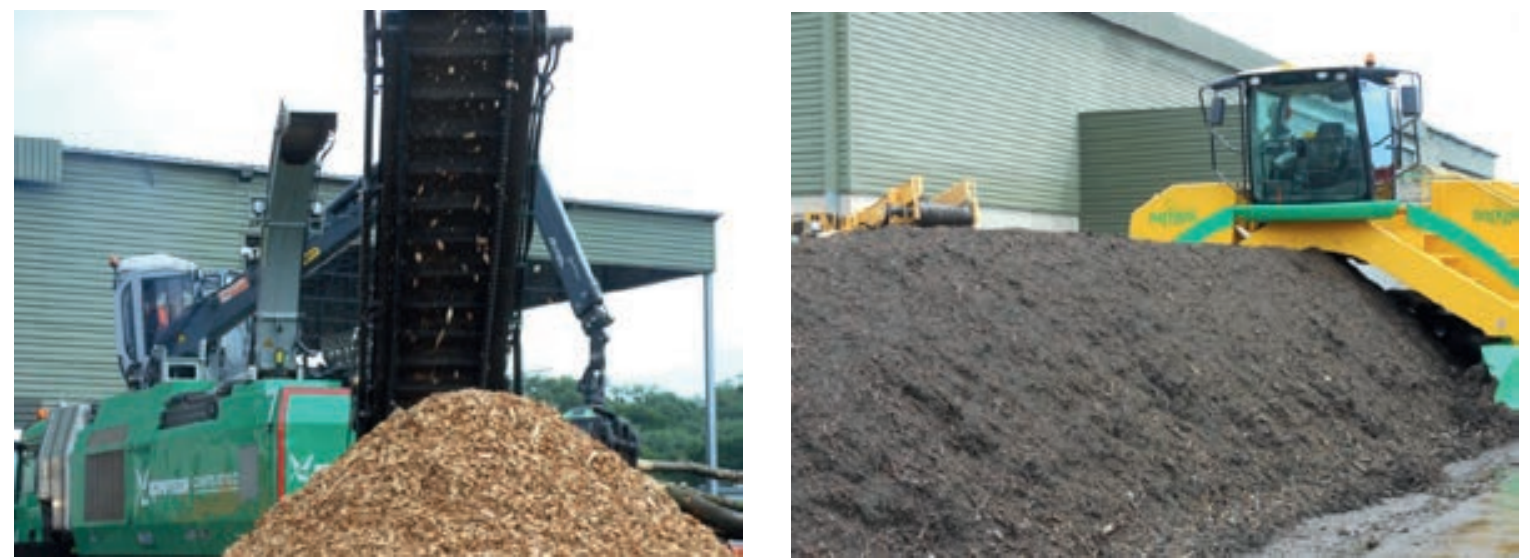

Figure 2.6 Mechanization has made large-scale composting possible: a drum chipper (left) and windrow turner (right).

Mechanization has gradually advanced, with the development of self-propelled turners which has greatly enhanced the efficiency of windrows ${ }^{9}$. Current composting systems can broadly be divided according to the level of technology used, and whether the facilities are open or closed to the environment. As the windrow system is unable to supply sufficient aeration to very moist feedstocks, the aerated static pile composting system was developed in the early 1970s in Beltsville, US. In this system, the windrows are located on top of an air distribution system, made of perforated pipes embedded in woodchips ${ }^{8}$. Aeration is forced through the static pile either by blowing (positive pressure) or by drawing (negative pressure). The forced aeration claims to shorten the active decomposition period from 40 days or more in the windrow system to about 21 days in the static pile system. The initial Beltsville system draws air into the pile through negative pressure. The drawbacks of this system were cooling of the outside of the pile, and high temperatures $\left(>80^{\circ} \mathrm{C}\right)$ in the core of the pile. 
Rutgers University developed the method of positive pressure (blowing), which allowed for both the right oxygen requirements and good temperature conditions ${ }^{10}$. Both the windrow system and the aerated static pile systems, are 'nonreactor' or open air composting systems.

Several closed reactor systems have been developed, such as the rectangular agitated beds system, where composting takes place between long walls that form narrow beds. Feedstocks enter at one end of the beds, and the compost turning machine moves the compost with each turning towards the end of the beds. The initial composting process is relatively short in closed systems and should be followed by a curing period to obtain sufficient maturity ${ }^{8}$.

Composting is not the same process as vermicomposting, although the products are both called 'composts'. Vermicomposting is a bio-oxidative process, in which litter-dwelling (epigeic), detritivorous earthworm species are involved in the decomposition of organic materials. Earthworms play a crucial role, as they fragment the organic matter and increase the surface area, but the actual decomposition is carried out by microbial organisms in the earthworm gut and their castings. The characteristics of vermicompost are thought to be highly influenced by these gut- and cast-associated processes. In Europe, 3 epigeic earthworm species are used for vermicomposting: Eisenia fetida, Eisenia andrei and Dendrobaena veneta ${ }^{11}$. One of the most employed earthworm species is Eisenia andrei, because of the high digestion rate of organic matter, its tolerance to environmental conditions, its high reproductive rate and short life cycle, and its resistance to handling ${ }^{12}$. In vermicomposting, two phases can be distinguished: (i) an active phase in which earthworms process the waste by physical comminution, ingestion and microbial decomposition, and (ii) a maturation-like phase when the earthworms move to fresher layers of undigested waste, and microbes provide further decomposition. The vermicomposting process differs from composting, in that the temperature remains in the mesophilic range. This enhances the chance of pathogen survival ${ }^{13}$.

The choice of the preferred composting method depends on the quantity (production scale) and quality of the input materials, the geographical and climatic situation and on preferences of the compost producer regarding e.g. labor requirements. Important aspects also include the degree of mechanization and the labor intensity of the system. Most existing systems are capable of producing good quality compost, but it is also possible to produce poor quality compost with all the existing methods. The difference between producing high or low quality compost is determined by the management of the composting process. The crucial factor is the adaptation of the management according to the system. A simple example is the size of the compost pile. The bigger the pile, the coarser the structure of the starting mixture has to be. Figure 2.7 gives a simplified overview of the composting process in three phases. The duration of the three temperature phases will differ according to the composting method. In Table 2.5 an overview of the most common composting systems in Europe is presented. The list is not exhaustive, but gives an idea of the scope of composting possibilities. 


$\begin{aligned} & \text { mesophilic phase thermophilic phase } \\ & \left(40-65^{\circ} \mathrm{C}\right)\end{aligned}$
$\begin{aligned} & \text { explosive growth less diverse population of } \\ & \text { co mesophilic } \\ & \text { bacteria and fungi and heat-tolerant fungi }\end{aligned}$

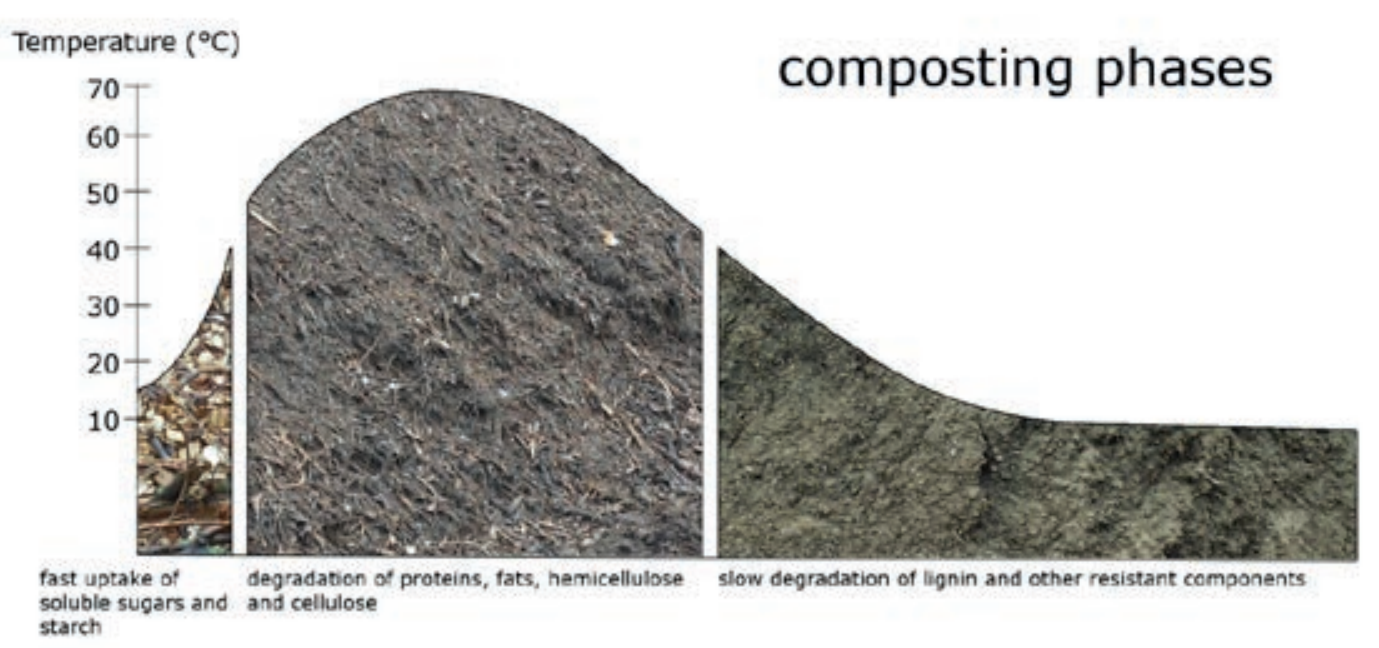

Figure 2.7 General overview of the three composting phases and the degradation processes taking place. The length of the different phases will differ, according to the composting method applied.

Table 2.5

Overview of common composting systems in Europe

\section{Field edge composting}

- Method appropriate for farmer with limited quantity of input material (up to 500-1,000 ton per year).

- Both solid manure and green waste can be treated with this method.

- No clear separation between environment and compost, it is difficult to assure weed free compost.

- Relatively low investment costs, but labor intensive.

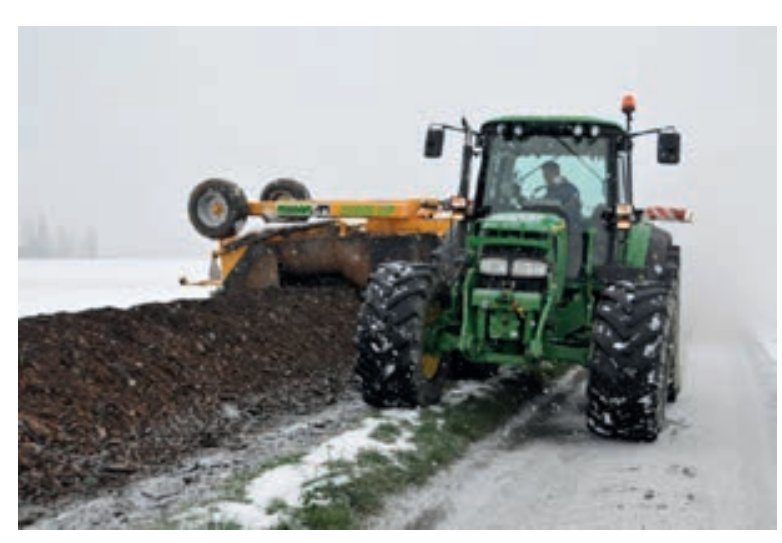

\section{Small windrows (up to $2 \mathrm{~m}$ high, 3-4 $\mathrm{m}$ wide)}

- Method appropriate to treat solid manure and green waste up to 5,000-6,000 ton per year.

- Clear separation between environment and compost.

- Each pile can be managed individually (starting mixture, maturation degree), so that it is possible to produce different composts for different applications.

- Medium investment costs. Relatively labor intensive. Needs a relatively high surface area.

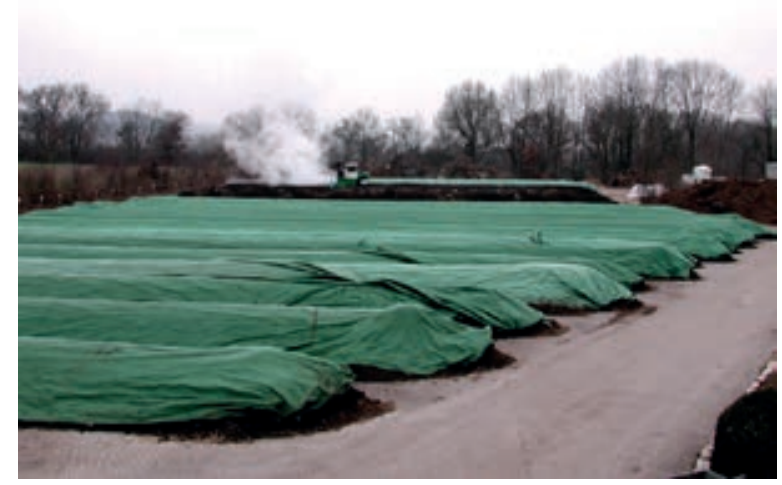




\section{Large windrows (up to $\mathbf{3 . 5} \mathrm{m}$ high, width not limited)}

- Method appropriate to treat large quantities of solid manure and green waste. Enough coarse structure material is needed to assure a good circulation of the air in the pile.

- Can be implemented with forced aeration.

- Clear separation between environment and compost.

- No clear separation between different compost batches.

- Relatively high investment costs, but low labor demands compared to smaller piles.

\section{Large windrows under roof (up to $3.5 \mathrm{~m}$ high, 5-6 m wide)}

- Method appropriate to treated 5-6,000 ton of solid manure and green waste per year. Enough coarse structure material is needed to assure a good circulation of the air in the pile.

- With forced aeration.

- Clear separation between environment and compost.

- Clear separation between different compost batches.

- High investment costs and relatively labor intensive (piles have to be turned with a wheel loader).

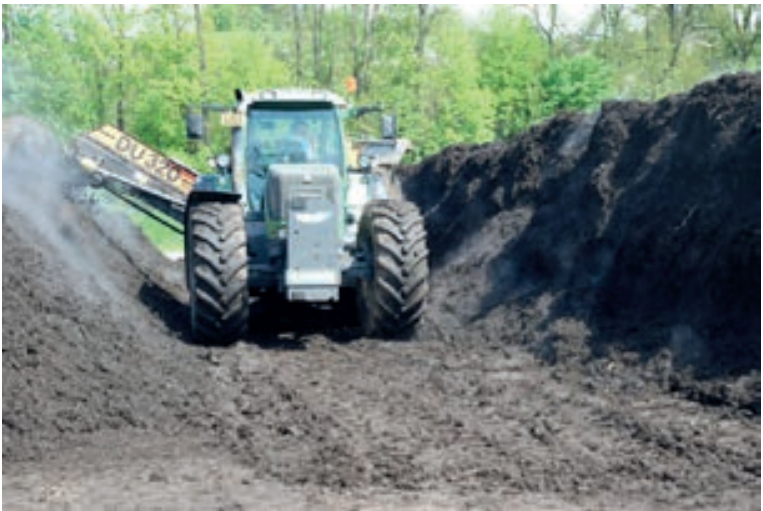

\section{Tunnel composting (approx. 2.5 m high, 5 m wide)}

- Method appropriate to treat large quantities of solid manure and green waste.

- Compost turning is regulated automatically.

- Can be implemented with forced aeration.

- Clear separation between environment and compost.

- Clear separation between different compost batches.

- The frequency of turning for a compost batch is fixed (given by the system)

- High investment costs. Low labor intensity.
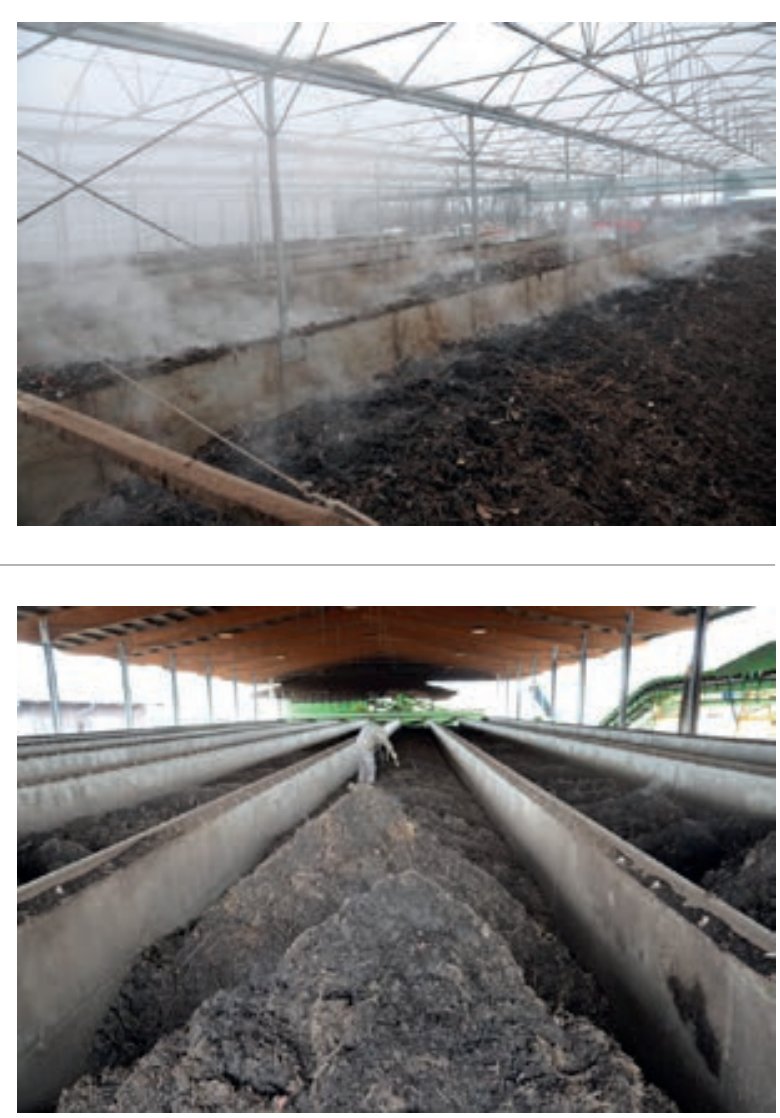
Box systems (approx. $3.5 \mathrm{~m}$ high, $6 \mathrm{~m}$ wide, $20 \mathrm{~m}$ long)

- Method appropriate to treat large quantities of solid manure and green waste.

- Compost turning, forced aeration and moisture control happen automatically

- Clear separation between environment and compost.

- Clear separation between compost batches.

- The distribution of the material over the box at the beginning of the process has to be homogeneous; otherwise the evolution of the composting process in a box will vary greatly from one part of the box to the other.

- High investment costs. Low labor intensity. Economic use of available surface area.

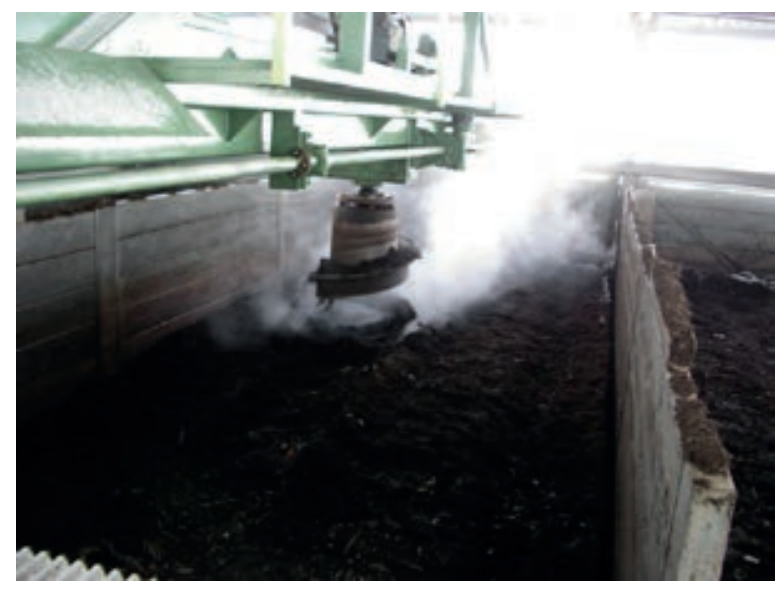

Hall composting (approx. $3.5 \mathrm{~m}$ high, 20 m wide)

- Method appropriate to treat large quantities of solid manure and green waste.

- Compost turning, forced aeration and moisture control automatically regulated.

- Clear separation between environment and compost.

- No clear separation between different compost batches.

- High investment costs. Low labor intensity.

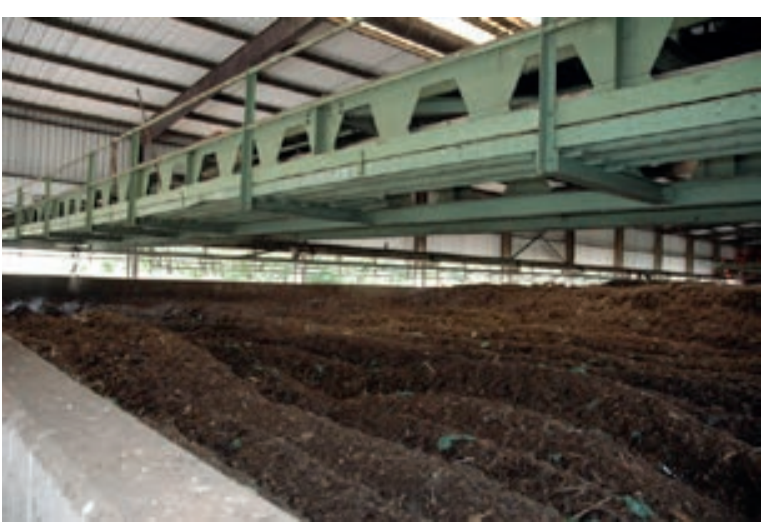

Container composting (approx. $2.5 \mathrm{~m}$ high, $2.5 \mathrm{~m}$ wide, 12 m long)

- Method appropriate to treat 5,000-10,000 ton of solid manure and green waste per year.

- Several containers are used in parallel. The fill of one container corresponds to one compost batch.

- The material will not be turned during the process. This system can better be combined with a postmaturation system (e.g. windrow).

- Clear separation between environment and compost.

- High investment costs and relatively labor intensive, but flexible system, which is relatively location independent.

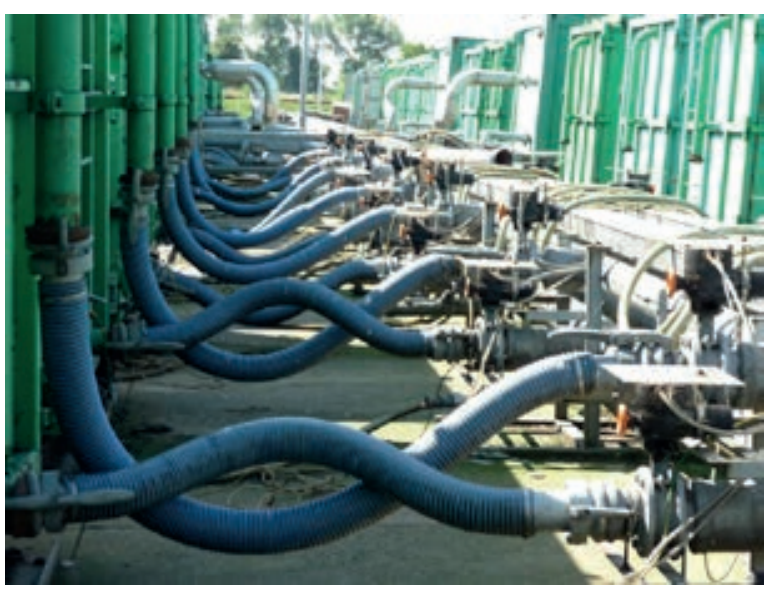




\subsection{Compost maturity}

One of the major factors that influences the type of compost is its degree of maturity. During the curing phase, several characteristics of the compost are changed, which greatly influence the effects of the compost on plant growth and soil fertility. A compost is considered to be 'young' at the end of the thermophilic phase, and 'mature' at the end of the curing phase. It is important to note that compost maturity cannot be expressed in terms of weeks or months. The time needed to reach a specific maturity level will vary greatly depending on the input material and the process management. The effective maturity level can be determined by the $\mathrm{NO}_{3}-\mathrm{N} / \mathrm{N}_{\min }-$ ratio (see Chapter 4).

In a young compost, easily decomposable organic materials (young grasses, lettuce leaves) are no longer discernable, but fibers and wood pieces are still recognizable. The majority of the mineralized nitrogen is present as ammonium $\left(\mathrm{NH}_{4}-\mathrm{N}\right)$. If the input material contains significant amounts of complex carbon compounds (lignin), this compost can immobilize the available nitrogen in the soil for a shorter or longer period of time. This type of compost still contains phytotoxic molecules (intermediate substances produced by the decomposition process), and can only be applied in moderate quantities when sensitive plants are cultivated or well in advance of planting.

In a mature compost, the degradation of organic materials is completed (except for larger pieces of wood that should be screened out), and a crumbly structure is formed, in which organic and mineral materials are clearly visible. The majority of the mineralized nitrogen is present as nitrate $\left(\mathrm{NO}_{3}-\mathrm{N}\right)$. Mature compost is compatible with plant growth and can be used in large quantities, provided that the salinity is not too high. Mature compost is therefore well suited as a component of growing media (Figure 2.8).

Table 2.6 summarizes different characteristics of combinations of feedstocks (carbon-rich or nitrogen-rich input materials) and maturity. A final factor determining the choice of compost is the price. Mature compost undergoes a longer curing process than young compost, which generally makes it more expensive. Specific requirements for compost quality versus costs should be weighed up when making the final choice.

Table 2.6

Influence of the combination of feedstock (nitrogen-rich or carbon-rich input materials) and maturity on compost characteristics

\begin{tabular}{lllll} 
Compost characteristics & \multicolumn{2}{l}{ Nitrogen-rich } & input materials & \multicolumn{2}{l}{ Carbon-rich input materials } \\
\cline { 2 - 5 } Nutrient content & young & mature & young & mature \\
\hline Risk of N-immobilization in soil & high & high & low & low \\
\hline Risk of phytotoxicity & low & no & high & no \\
\hline Stable humic acids content & high & low & high & low \\
\hline Color of the water extract (humus content) & medium dark & light & dark & medium light \\
\hline Risk of salinity & high & high & low & low \\
\hline Risk of leachate damage & medium & low & high & low
\end{tabular}



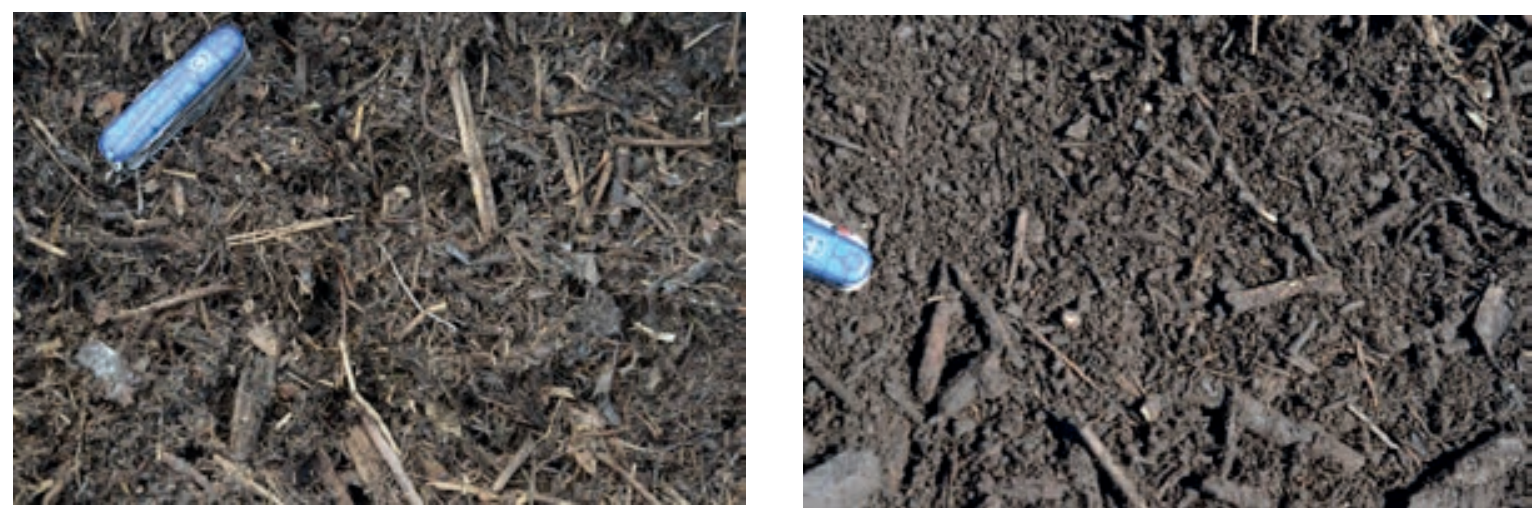

Figure 2.8 Structure of different types of compost. Left: young, carbon-rich compost, right: mature carbon-rich compost

\subsection{References}

1. Dewes T., Hünsche E. (1998).

Composition and microbial degradability in the soil of farmyard manure from ecologically-managed farms. Biological Agriculture and Horticulture, 16(3): 251-268.

2. Bokhorst J., Ter Berg C. (2001).

Handboek Mest \& Compost: behandelen, beoordelen \& toepassen. Driebergen: Louis Bolk Institute, $292 p$.

3. Reijneveld J.A., Abbink G.W., Termorshuizen A.J., Oenema O. (2014).

Relationships between soil fertility, herbage quality and manure composition on grassland-based dairy farms. European Journal of Agronomy, 56: 9-18.

4. Tiquia S.M., Tam N.F.Y. (2002).

Characterization and composting of poultry litter in forced-aeration piles. Process Biochemistry, 37(8): 869-880.

5. Vandecasteele B., Reubens B., Willekens K., De Neve S. (2013).

Composting for Increasing the Fertilizer Value of Chicken Manure: Effects of Feedstock on P Availability. Waste and Biomass Valorization, 5(3): 491-503.

6. Whalen J.K., Chang C., Clayton G.W., Carefoot J.P. (2000).

Cattle manure amendments can increase the $\mathrm{pH}$ of acid soils. Soil Science Society of America Journal, 64(3): 962-966.

7. Blum B. (1992).

Composting and the Roots of Sustainable Agriculture. Agricultural History, 66(2): 171-188.

8. Fitzpatrick G.E., Worden E.C., Vendrame W.A. (2005).

Historical Development of Composting Technology during the 20th Century. HortTechnology, 15(1): 4851.

9. Raviv M. (2015).

Can the use of composts and other organic amendments in horticulture help to mitigate climate change? Acta Horticulturae 1076: 19-28.

10. Leton T.G., Stentiford E.I. (1990).

Control of aeration in static pile composting. Waste Management \& Research, 8(4): 299-306.

11. Rorat A., Suleiman H., Grobelak A., Grosser A., Kacprzak M., Płytycz B., et al. (2015).

Interactions between sewage sludge-amended soil and earthworms-comparison between Eisenia fetida and Eisenia andrei composting species. Environmental Science and Pollution Research, 23(4): 30263035.

12. Domínguez J., Gómez-Brandón M. (2013).

The influence of earthworms on nutrient dynamics during the process of vermicomposting. Waste Management \& Research, 31(8): 859-868.

13. Lazcano C., Gómez-Brandón M., Domínguez J. (2008).

Comparison of the effectiveness of composting and vermicomposting for the biological stabilization of cattle manure. Chemosphere, 72(7): 1013-1019. 
44 I Handbook for Composting and Compost Use in Organic Horticulture 


\title{
3 Microbiology of the composting process
}

\author{
Marta A. Streminska and Michael Raviv
}

In short:

- Composting is a process of transforming fresh organic matter into stable humus-like substances.

- Composting is carried out by microorganisms (bacteria and fungi).

- Thermophilic composting is the most common process. To be optimal, it requires the process to go through a phase in which the temperature in compost pile reaches levels above $60^{\circ} \mathrm{C}$. Under these conditions, also most plant and human pathogens are eradicated along with seeds.

- Microorganisms degrade organic matter to produce $\mathrm{CO}_{2}$, water and energy.

- In each stage of composting and compost storage, different groups of bacteria and fungi are active to produce the end product: compost.

\subsection{The composting process}

Composting is a natural process in which fresh organic matter (animal manure, food wastes, green wastes, agricultural residues, etc.) is transformed into more stable humus-like substances, nutrients are being "recycled" and energy is being produced ${ }^{1}$. The process should be aerobic and part of it is carried out under thermophilic conditions. Thorough composting of organic materials achieves a number of important objectives. It eliminates phytotoxicity, eradicates pathogens and weed seeds (see chapter 5), and stabilises the material with respect to $\mathrm{N}$ and oxygen demand, thus preventing $\mathrm{N}$ immobilization by soil biota, which compete with the plant for the limited $\mathrm{N}$ resources. Composting results in an easily handled material that can be used as soil improver and as a component of growing media. The subject of compost production for horticultural purposes was previously reviewed ${ }^{2,3}$.

After the initial period of a few days the temperature will typically increase to over $60^{\circ} \mathrm{C}$ unless it is controlled. This is the thermophilic stage. It lasts until all the easily decomposable organic matter has been broken down. It is important for uniform composting that all of the material is exposed to similar temperatures. This is accomplished in many systems by regular turning of the compost pile or by a rotary drum composter. Where turning is not carried out as in static piles, temperature uniformity throughout the pile may be problematic and homogenization methods should be considered in the design of the composting system. Once the easily decomposable matter is decomposed, the temperature starts to decrease and as it falls below $40^{\circ} \mathrm{C}$ the compost will be re-invaded by mesophilic microorganisms, including nitrifying bacteria. In the last stage, the active composting phase gives way to the curing period where the compost matures and becomes ready for use. Composting has been used for centuries ${ }^{4}$. However, the first evidence to su[pport the hypothesis that it is a biological process was only obtained about a hundred years ago. Microorganisms play the main role in the process as they are responsible for the degradation of organic matter.

\subsection{What are microorganisms?}

Microorganisms are small living organisms. They are present almost everywhere: in the soil, water and air. They are also abundantly present in human and animal intestinal tracts, on human skin etc.

The two major groups of microorganisms which are important in the process of composting are bacteria and fungi. Bacteria are very small and invisible to the naked eye. We can see bacteria when they form colonies on synthetic medium plates, for example (Figure 1). Some bacteria may form groups or filaments (such as Actinomycetes). Although they are small relative to fungi, their strength lies in numbers. Bacteria usually decompose readily available organic matter such as sugars more quickly than fungi ${ }^{1}$. They are therefore important in the first stages of composting, high levels of carbohydrates are available in the feedstocks. 
Actinomycetes is a specific group of bacteria, which was previously classified as a separate microbial group. Actinomycetes may look more like fungi to the untrained eye because they form filaments. This group has slightly different nutritional preferences than other bacteria. They can degrade more complex molecules such as hemicellulose, starch or even lignin. They are more abundantly present in the later stages of composting, when the majority of easily degradable substrates have already been used up 5 . Fungi compromise a group of larger organisms. They often form hyphen, which are strands of cells that are just visible to the naked eye. This is why people initially believed that only fungi contributed to the composting process. Fungi tend to be more important in the later stages of composting, when more resistant substances are being decomposed, such as hemicellulose, lignin and pectin ${ }^{1}$. Some examples of how bacteria and fungi isolated from compost appear are given in Figure 3.1 .
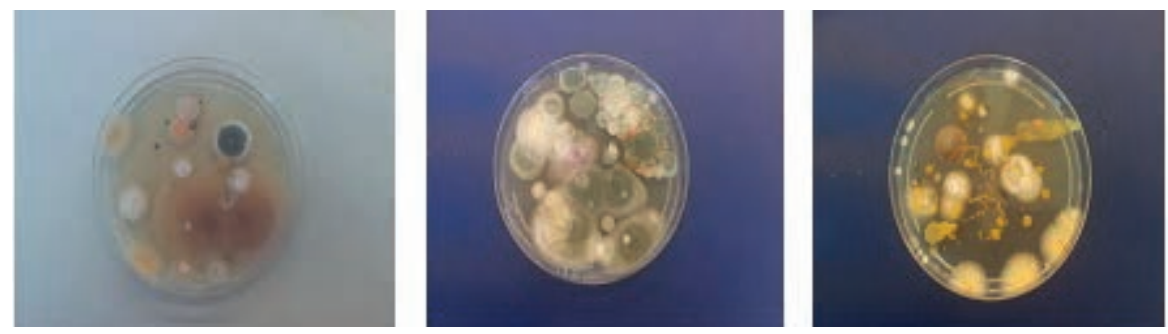

Figure 3.1 Examples of bacteria and fungi isolated from compost and grown on synthetic media on a Petri dish.

\subsection{Where do the microorganisms in the compost come from?}

Each type of organic matter that is being used as a feedstock for composting harbours a plethora of bacteria and fungi. It is difficult to generalise about microbial presence in different composting feedstocks. Which groups of microorganisms and how many of them are present is controlled by a number of factors, among them the type of organic matter, water content and temperature ${ }^{6}$. Microbial numbers and identities will be certainly different in wood chips than in cattle manure.

The diversity of microorganisms in different feedstocks is beneficial to the composting process as different microorganisms can decompose different types of organic molecules. This process is started by microorganisms, and their own activity changes the characteristics of the organic matter available to them. This in turn causes changes in microbial community, with specific physiological groups being more prevalent than others at a given time in the composting process.

\subsection{Why do microorganisms do it?}

Microorganisms are alive. Just like humans, animals and plants they need energy and nutrients to survive. Thus, bacteria and fungi need "food". Some bacteria can produce energy while using only inorganic substances. Others need organic carbon (C) compounds to be able to grow. These microorganisms are called heterotrophs. Organic feedstocks used for composting are rich in organic matter that microorganisms can degrade. In northern Europe feedstocks for composting are mainly of plant origin while components of animal origin are used less often. In other parts of the world, the use of animal manure is very common. In addition, the composting of carcasses is an efficient and environmentally- friendly method of treating the problem of infectious disease outbreak? Similarly, composting of slaughterhouse wastes is an excellent way to recycle this nutrient-rich waste ${ }^{8}$. It should be noted that plant wastes are frequently too bulky. Bulky material should be first shredded to reduce particle size and to promote microbial invasion into the substrate to accelerate the composting process. Shredding also improves handling of the material and facilitates pre-screening and mixing.

Feedstocks contain high amount of sugars, carbohydrates, proteins, cellulose, hemicellulose and lignin ${ }^{1}$. These compounds serve as a readily-available energy source for the growth of bacteria and fungi. Microorganisms produce carbon dioxide, water and energy during the aerobic (in the presence of oxygen) degradation of organic compounds. This process is called respiration (Figure 3.2). 


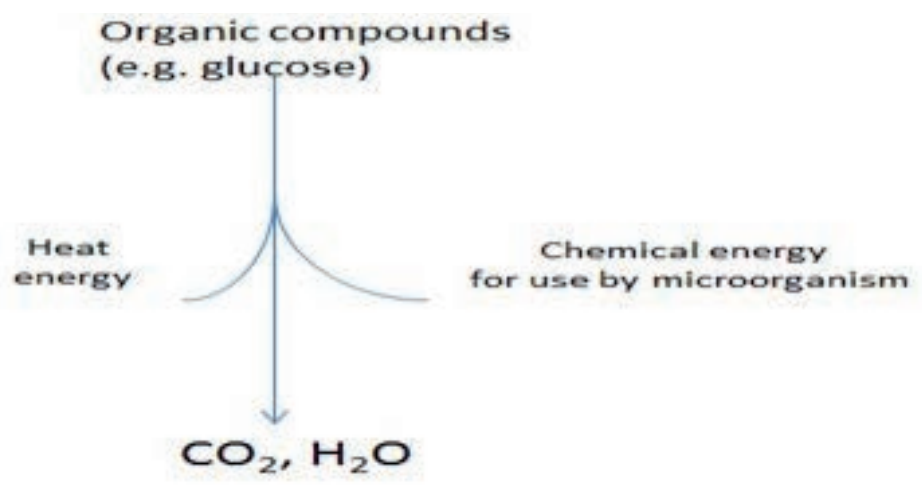

Figure 3.2 Schematic overview of aerobic (in presence of oxygen) degradation of organic compounds: microorganisms produce carbon dioxide $\left(\mathrm{CO}_{2}\right)$, water and energy.

Microbes, similarly to humans, do not use the energy with full efficiency. A significant amount of energy produced during respiration is lost as heat. In natural conditions (e.g. forest or agricultural soil) this does not result in significant increase in temperature of the environment, as most of the generated heat is dissipated to the surroundings. During composting, however, organic matter is stored in piles, windrows or enclosed drums and heat dissipation is limited. Thus the temperature of a compost pile increases during microbial activity. The degree of heating during the composting process is determined by the degradability and energy content of the substrates along with oxygen and moisture availability. Microbial activity is regulated by the heat generated and the quality of organic matter remaining in the compost pile. These factors also influence which microorganisms are present at each stage of composting ${ }^{5,9}$.

\subsection{What microorganisms need to be able to do all the work?}

\subsubsection{Nutrients}

Above we mentioned that most microorganisms need organic carbon compounds (C) but they cannot live only on carbon. Like every other living organism, they need to be supplied with macronutrients (such as $\mathrm{N}, \mathrm{P}, \mathrm{K}, \mathrm{Mg}, \mathrm{S}$ ) and microelements.

Probably one of the most important elements that microorganisms need, besides carbon, is nitrogen $(\mathrm{N})$. It is needed for the synthesis of proteins, amino acids and DNA. Microorganisms need significantly more $\mathrm{N}$ than plants, on a weight for weight basis. The average $\mathrm{C}: \mathrm{N}$ ratio of bacteria is about 10 , while in some plant tissues it can be as high as $100^{1}$. When $\mathrm{N}$ supply is limited, the composting process slows down. Therefore, in composting practice, it is very important to create a good feedstock mix with an optimal C: $\mathrm{N}$ ratio. It has been reported that the optimum C: $\mathrm{N}$ ratio for composting is varies between 25 and $35^{10}$. If starting material has a $\mathrm{C}: \mathrm{N}$ ratio of less than 25 it can be degraded too quickly, hence producing too much heat causing ashing. $\mathrm{N}$ will be then lost to the air in the form of ammonia $\left(\mathrm{NH}_{3}\right)$ gas. If the $\mathrm{C}: \mathrm{N}$ ratio is above 35 , then degradation of organic matter might slow down significantly. If the value is higher, the rate of decomposition will be slow and the resulting compost may not be properly stabilised. High temperatures cannot be reached under these conditions and seeds, plant and human pathogens can survive. The $\mathrm{C}: \mathrm{N}$ ratio decreases during the process itself because part of the carbon is lost as $\mathrm{CO}_{2}$ gas from microbial respiration, while most of $\mathrm{N}$ is retained in the system ${ }^{5}$.

The desired $\mathrm{C}: \mathrm{N}$ ratio can be achieved by analysing the feedstocks and correcting the $\mathrm{C}$ or $\mathrm{N}$ contents. Green waste may typically have a C:N ratio of 45-50 and would need to be combined with a material with a high $\mathrm{N}$ content such as food waste or poultry litter in order to produce a satisfactory compost. The $\mathrm{N}$ content is measured as total Kjeldahl $\mathrm{N}$ while the $\mathrm{C}$ content can be estimated from the ash content ${ }^{11}$ by:

$\% \mathrm{C}=(100-\%$ ash $) / 1.8$ 
It should be noted that while the C:N ratio is routinely used as an indicator of "compostability", there are significant differences in the biodegradability of various organic materials that are unrelated to the C:N ratio ${ }^{10}$. As mentioned above, the $\mathrm{C}: \mathrm{N}$ ratio falls during composting as $\mathrm{CO}_{2}$ is formed, and a final value of around 15 is generally aimed for, as one of the indicators for compost maturity.

$\mathrm{N}$ contained in composting feedstocks is predominantly in organic form ${ }^{12}$. During the first steps of composting, decomposition of amino acids leads to the formation of ammonium $\left(\mathrm{NH}_{4}\right)$. Due to its relatively low solubility, ammonia gas $\left(\mathrm{NH}_{3}\right)$ may soon be lost to the air. The water solubility of $\mathrm{NH}_{3}$ at regular $\mathrm{pH}$ levels is low. However, $\mathrm{NH}_{3}$ solubility increases however, when the $\mathrm{pH}$ is lowered to 6 so more $\mathrm{N}$ can be retained. To conserve $\mathrm{N}$ in the system, a special group of bacteria, called nitrifying bacteria, mineralises $\mathrm{NH}_{3}$ gas via nitrite $\left(\mathrm{NO}_{2}\right)$ to nitrate $\left(\mathrm{NO}_{3}\right)$. These bacteria need oxygen to be able to complete this transformation. Unfortunately, these bacteria are purely mesophilic so $\mathrm{NH}_{3}$ is bound to be lost during the thermophilic stage. Nitrification starts once the composting process is generating less heat. Initially it is slow and it only reaches full capacity during the curing stage. $\mathrm{NO}_{3}$ can later be used by plants as an $\mathrm{N}$ source. The ratio between $\mathrm{NO}_{3}-\mathrm{N}$ and $\mathrm{NH}_{4}-\mathrm{N}$ is often used as an indicator of compost maturity (see chapter 4). In mature compost the majority of the soluble inorganic nitrogen will be present in nitrate form, which cannot be further oxidised. The transformation routes of nitrogen during composting and compost storage are shown in Figure 3.3.

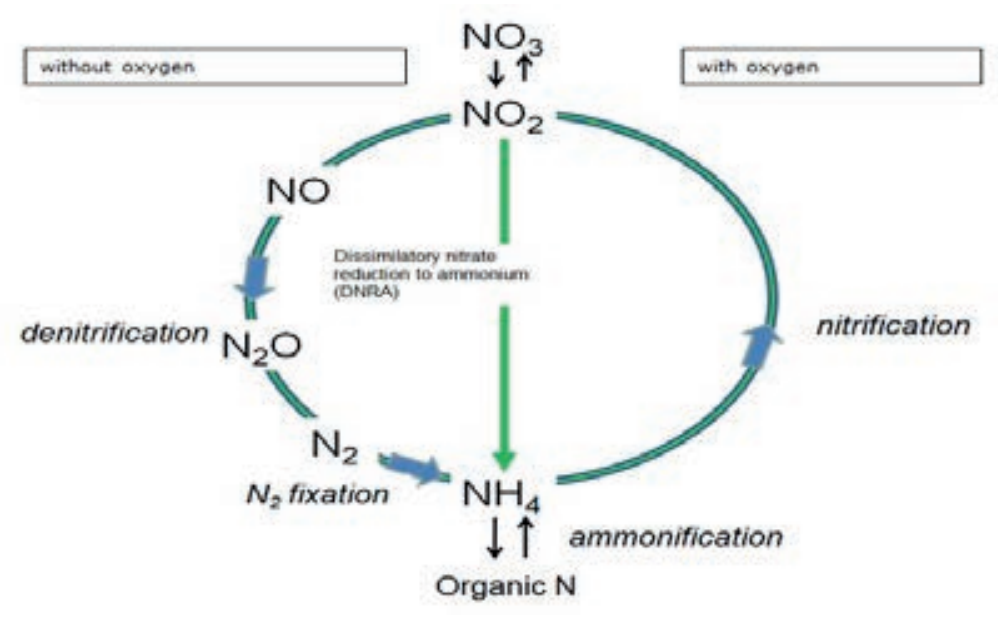

Figure 3.3 The nitrogen cycle during composting (modified after Maeda at al., 2011).

\subsubsection{Oxygen}

Composting would not take place without a sufficient supply of oxygen $\left(\mathrm{O}_{2}\right)$. If insufficient oxygen is present, then aerobic microorganisms are replaced by microorganisms which are able to survive without oxygen. These anaerobic microorganisms begin degrading organic matter in a process called fermentation. This type of transformation leads to incomplete oxidation of organic compounds to $\mathrm{CO}_{2}$, water and heat. As a result, some undesired organic compounds such as volatile fatty acids are produced, causing bad odours and turning the compost phytotoxic. Good aeration is also necessary for the complete nitrification process (oxidation of NH3/ $\mathrm{NH}_{4}$ to $\mathrm{NO}_{3}$ ) mentioned in Chapter 3.4.1. Nitrite $\left(\mathrm{NO}_{2}\right)$ from the first step of nitrification may accumulate without sufficient oxygen ${ }^{6}$. Nitrite is toxic to many microorganisms and plants. $\mathrm{NO}_{2}$ may also accumulate during the storage of insufficiently aerated compost. $\mathrm{NO}_{3}$ is then reduced via $\mathrm{NO}_{2}$ to nitrogen gas $\left(\mathrm{N}_{2}\right)$ in the process called denitrification carried out by anaerobic bacteria.

Although a compost pile is mostly an aerobic environment, zones with little or no oxygen can also exist ${ }^{5}$. They form in places, where microbial activity is so high that oxygen is not being replenished fast enough. It is therefore important to remember to turn the pile frequently to enable proper aeration. It is also important to remember that bacterial activity in compost does not cease at the end of composting process. There are still bacteria present in the compost and to guarantee good quality compost, it has to be properly stored (aerated, not too dry $)^{13}$. Only then will the possibility of nitrate losses via denitrification and rotting of compost be avoided. 


\subsubsection{Water}

Microorganisms also need water $\left(\mathrm{H}_{2} \mathrm{O}\right)$ in addition to nutrients and oxygen. They cannot function in dry environments. Fungi tend to be less sensitive to a lack of water. Bacteria however, need water to survive. They can only survive in water film on surfaces. Therefore, moisture content is a very important factor in composting. If the pile is too dry, composting will not occur. A moisture content of $30 \%$ is often proposed as a minimum and $45-55 \%$ as the optimum during the thermophilic phase. It is important, however, not to overwater the compost pile. A high moisture content makes diffusion of oxygen to deeper parts of the pile difficult. This results in oxygen depletion, and microorganisms begin to ferment the organic matter instead of composting. Thus, the key is to keep the composting pile moist but not too wet. Overwatering may also cause leaching of nutrients and environmental pollution. Optimum moisture content is also essential for proper cooling of the compost to prevent overheating and ashing of the organic matter.

\subsection{How do microorganisms do it?}

Microbial populations within the composting pile change during the process. We mentioned earlier that microbial communities vary in different feedstocks. That is true at the starting point of composting but, microbial populations change quickly after the beginning of the process. At the end each compost pile goes through specific phases, which are linked with specific metabolic processes. How and why this happens will be explained below.

We will focus on one type of composting: hot composting. Other types, such as cold composting and vermicomposting will not be discussed here, because they are rarely used for the production of large quantities of compost for horticultural use.

Historically, hot composting was done in a batch system. In such a production system, the composting process is usually divided into four distinct phases ${ }^{4}$. The duration of each phase may differ depending on which feedstocks are being composted, on the composting method and on the ambient climate. Continuous systems for compost production are currently gaining popularity. They also rely on hot composting, but the different phases are separated in space rather than in time.

Below we explain what happens during traditional hot composting in which compost is produced in batches.

\subsubsection{Warming-up Phase $\left(25-40^{\circ} \mathrm{C}\right)$}

After the material has been ground any required additives such as poultry litter have been added, and moisture content has been optimised ( $50 \%$ ), the temperature begins to rise as microbiological activity increases. The degradation of organic matter proceeds rapidly during the initial stage of composting. Organic matter is characterised by high percentage of easily degradable compounds, such as sugars and proteins. Bacteria are better competitors for easily degradable carbon sources, thus fungi are quickly outcompeted by them. The warming-up stage is usually short lasting, taking only a couple of days. Microorganisms are so active that their metabolism produces a lot of heat energy, leading to a quick temperature rise.

At this stage bacteria such as Lactobacillus and Acetobacter are often present ${ }^{5}$. These are bacteria that produce organic acids such as lactic and acetic acids. There might be even an intermediate accumulation of these acids in the first few days of composting. Other groups of bacteria, usually present in the composting pile, degrade these organic acids quickly.

The temperature continues to rise and some bacteria are unable to function in such an environment. Microorganisms adapted to higher temperatures, gradually replace the mesophilic bacteria and fungi. This is when the second phase starts.

\subsubsection{Thermophilic Phase $\left(40-65^{\circ} \mathrm{C}\right)$}

During this phase the decomposition process proceeds rapidly leading to the production of more heat energy. Temperature in the core of the compost pile can reach up to 65 and even $70^{\circ} \mathrm{C}$. The organic matter that is being degraded now is more complex, like cellulose, lignin and fats. There is also a pH increase due to high ammonia emission from proteins. 
Thermophilic bacteria like Bacillus and Actinomycetes dominate the microbial community in the thermophilic phase ${ }^{1}$. Fungi are normally not active at temperatures above $55^{\circ} \mathrm{C}$ except for some thermophilic species. One exception is the composting of substrates that are particularly rich in cellulose and in lignin. In these cases, fungi remain important degraders throughout the entire process.

\subsubsection{Cooling Phase (Second Mesophilic Phase)}

Microbial degradation slows down significantly, when the availability of almost all organic substrates becomes limited. Thus, less heat energy is produced and temperature of the compost pile declines. Compost is recolonized by bacteria which prefer temperatures around $25-40^{\circ} \mathrm{C}$. During the warming-up phase, organisms that degraded sugars, oligosaccharides and proteins dominated the microbial community. In the cooling phase microorganisms with similar temperature tolerance, but with different metabolic activities dominate. The chemical characteristics of the compost pile differ significantly before and after the heat phase. The compost pile contains only complex organic compounds after the heating phase. Microorganisms capable of degrading them are therefore present in large numbers. During the cooling phase many cellulose degrading bacteria colonize the compost ${ }^{5}$. Fungi such as Aspergillus get their chance to grow in the compost. Compost is also colonised by bacteria and fungi that can be beneficial for plant growth and health, such as mycoparasitic Trichoderma species. The limited availability of readily degradable carbon leads to microorganisms employing different strategies to compete for it. One strategy is antibiotic production by Actinomycetes, which are aimed against fungi. These compounds can later on be effective against plant pathogenic fungi.

\subsubsection{Maturation and Curing Phase}

The compost does not contain a lot of viable energy sources for heterotrophic bacteria after the cooling phase. The microbial community is therefore gradually and slowly transformed. Bacterial species with lower dependency on readily available organic carbon are now colonising the compost. Fungi also begin to flourish, because they are better equipped to use the remaining substrates such as lignins. Microorganisms remain active in compost but changes to the chemical characteristics of compost caused by their activity are not as evident as during the thermophilic phase of composting.

\subsubsection{Compost maturity}

The stability and maturity of compost are important characteristics in relation to its use in organic horticulture. The terms stability refers to the stage when temperatures fall to the ambient level while maturity refers to its readiness to support plant growth with no signs of phytotoxicity, excessive $\mathrm{O}_{2}$ consumption or $\mathrm{N}$ immobilization. If active decomposition continues after soil incorporation, plant growth will be negatively affected due to reduced levels of available $\mathrm{O}_{2}$ and $\mathrm{N}$ and/or the presence of phytotoxic compounds. Several tests have been developed to evaluate the stability maturity/phytotoxicity of composts. Common stability and maturity tests are respirometric tests based on $\mathrm{O}_{2}$ consumption and $\mathrm{CO}_{2}$ evolution ${ }^{14}$ or self-heating tests ${ }^{15}$. The rate of heat production using microcalorimetry was suggested as a very sensitive measure of compost maturity ${ }^{16}$. Chemical tests such as the $\mathrm{NO}_{3}: \mathrm{NH}_{4}$ ratio, $\mathrm{C}: \mathrm{N}$ ratio and content of volatile organic acids are used in various countries to assess compost maturity ${ }^{17}$. Inbar et al. ${ }^{18}$ used solid state ${ }^{13} \mathrm{C}$ nuclear magnetic resonance and infrared spectroscopy to determine the degree of composting. Phytotoxic tests are based on bioassays that screen for negative impacts on seed germination and plant growth. 


\subsection{References}

1. Insam H., de Bertoldi M. (2007).

Microbiology of the composting process Chapter 3 in book: Compost Science and Technology (edited by L.F. Diaz, M. de Bertoldi, W. Bidlingmaier)

2. Raviv, M. (2005).

Production of high-quality composts for horticultural purposes - a mini-review. HortTechnology 15: 52-57.

3. Bernal, M.P., Alburquerque, J.A. and Moral R. (2009).

Composting of animal manures and chemical criteria for compost maturity assessment. A review.

Bioresource Technol. 100(22):5444-5453.

4. Rawat S., Johri B.N. (2013).

Role of Thermophilic Microflora in Composting. Thermophilic Microbes in Environmental and Industrial Biotechnology (ed.: Satyanarayana, T., Littlechild, J., Kawarabayasi Y.) pp. 137-169

5. Ryckeboer J., Mergaert J., Vaes K., Klammer S., De Clercq D., Coosemans J., Insam H., Swings J. (2003). A survey of bacteria and fungi occurring during composting and self-heating processes. Annals of Microbiology, 53 (4), 349-410

6. Fuchs J. (2010).

Interactions between Beneficial and Harmful microorganisms: from the composting process to compost application in "Microbes at work" (eds: . Insam et al.)

7. Glanville, T. D., Ahn, H. K., Richard, T. L., Harmon, J. D., Reynolds, D. L. and Akinci, S. (2013).

Effect of envelope material on biosecurity during emergency bovine mortality composting. Bioresource Technology 130: 543-551.

8. Franke-Whittle, I.H. and Insam, H. (2013).

Treatment alternatives of slaughterhouse wastes, and their effect on the inactivation of different pathogens: a review. Critical Reviews in Microbiology 39(2):139-151.

9. Partanen P, Hultman J, Paulin L, Auvinen P, Romantschuk M. (2010).

Bacterial diversity at different stages of the composting process. BMC Microbiology. 2010 Mar 29;10:94. doi: 10.1186/1471-2180-10-94

10. Day, M and Shaw. K. (2001).

Biological, chemical and physical processes of composting In: Stofella, P. J and Kahn, B. A. (eds.)

Compost utilization in horticultural cropping systems. CRC Press LLC, Boca Raton, Fla., USA.

11. Golueke, C. G. (1972).

Composting, a study of the process and its principles. Rodale Press, Emmaus, Pa., USA.

12. Toyoda S, Yoshida N, Morioka R, Osada T. (2011).

Microbiology of nitrogen cycle in animal manure compost. Microbial Biotechnology 4:700-709

13. Saadi, I., Laor, Y., Medina, Sh., Krasnovsky, A. and Raviv, M. (2010).

Compost suppressiveness against Fusarium oxysporum was not reduced after one-year storage under various moisture and temperature conditions. Soil Biology and Biochemistry 42: 626-634.

14. Villasenor, J., Perez, M.A., Fernandez, F.J. and Puchalski, C.M. (2011).

Monitoring respiration and biological stability during sludge composting with a modified dynamic respirometer. Bioresource Technology 102: 11, 6562-6568.

15. Kuhner, M. and Sihler, A. (1996).

Assessment of compost maturity. The science of composting: part 2: 1199-1204.

16. Laor Y., Raviv M., Borisover M. (2004).

Evaluating microbial activity in composts using microcalorimetry. Thermochimica Acta 420: 1-2, $119-125$

17. Hogg, D., Barth, J., Favoino, E., Centemero, M., Caimi, V., Amlinger, F., Devliegher, W., Brinton, W., and Antler, S. (2002).

Comparison of compost standards within the EU, North America and Australasia. The Waste and Resources Action Programme, Banbury, UK.

18. Inbar, Y., Chen, Y. and Hadar, Y. (1989).

Solid state carbon 13 nuclear magnetic resonance and infrared spectroscopy of composted organic matter. Soil Sci. Soc. Amer. J. 53:1695- 1701 
52 I Handbook for Composting and Compost Use in Organic Horticulture 


\title{
$4 \quad$ What control measures do we need for compost production and use
}

\author{
Jacques G. Fuchs, Leen Janmaat and Michael Raviv
}

\section{In short:}

- The management of the composting process depends on the periodical control of temperature, moisture content and oxygen concentration.

- The determination of the quantities of ammonium $\left(\mathrm{NH}_{4}-\mathrm{N}\right)$, nitrite $\left(\mathrm{NO}_{2}-\mathrm{N}\right)$ and nitrate $\left(\mathrm{NO}_{3}-\mathrm{N}\right)$ in the compost allows the evaluation of its maturity, the quality of the composting process and of the storage of the product, and the risk of $\mathrm{N}$ immobilization or release in the soil.

- Plant phytotoxicity tests can assess the maturity and the quality of the produced compost.

- The choice of the appropriate compost, application strategy and use, should be guided by analyses of pHvalue, salinity, intensity of colour extract and nutrient content.

As described in chapter 2, there are various composting methods as well as a range of compost types. However, the biological process, described in chapter 3, is similar and independent of the technology used. Hence, the relevant parameters that allow the control of the composting process and the quality of the produced compost are basically similar for all systems. These parameters are important, in combination with a few others, for the determination of the quality of the composts produced and the selection of the right compost for the defined application. It is also important to produce a protocol for the process.

\subsection{Production control measures}

\subsubsection{Temperature}

Due to the very intensive microbiological activity at the beginning of the composting process, the temperature in the windrow increases up to $60^{\circ} \mathrm{C}$ or more (Figure 4.1). After some time, the temperature decreases again and the composting process goes from the decomposition phase (Figure 4.1, yellow part) to the maturation phase (Figure 4.1, white part). 


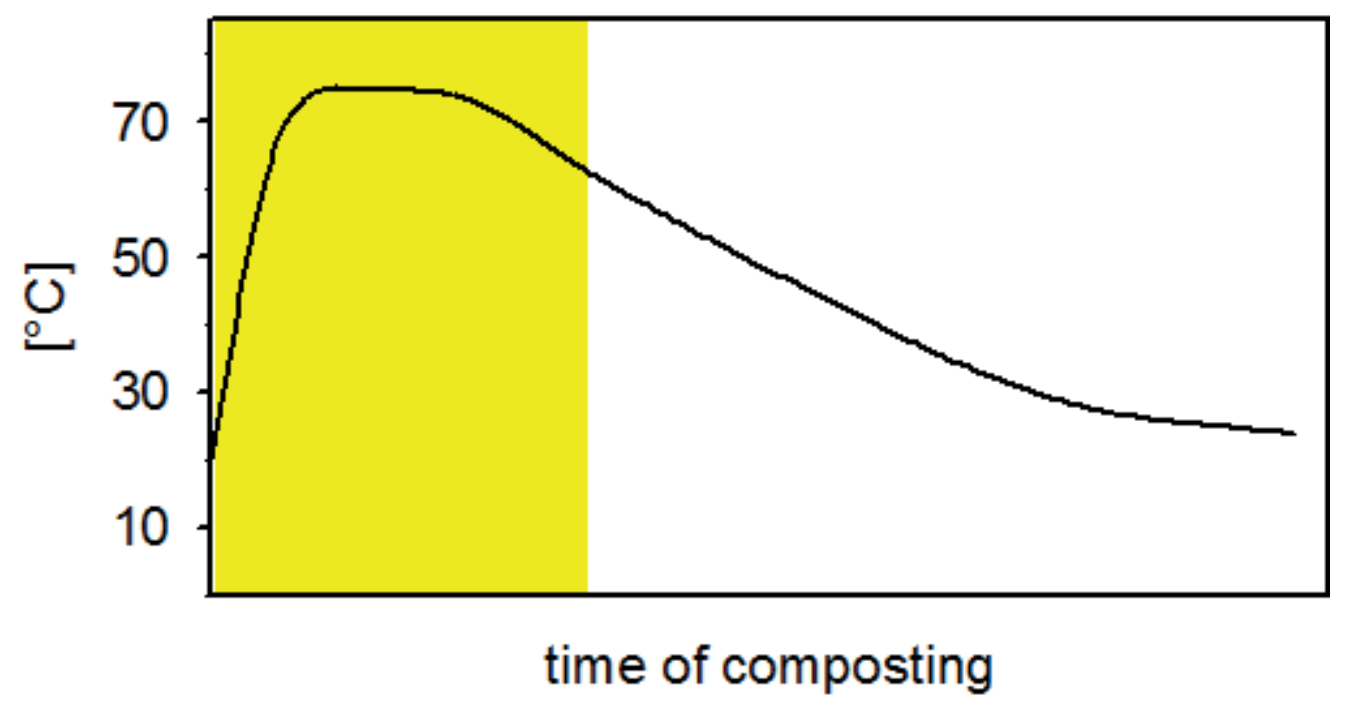

Figure 4.1 Theoretical evolution of the temperature in the compost piles during the composting process (Graph: Ulrich Galli).

Temperature course within an aerated pile +3 turnings

(Separated cattle manure + tomato plants, set-point $=60$ ㅇ) .

Active period: 90 days

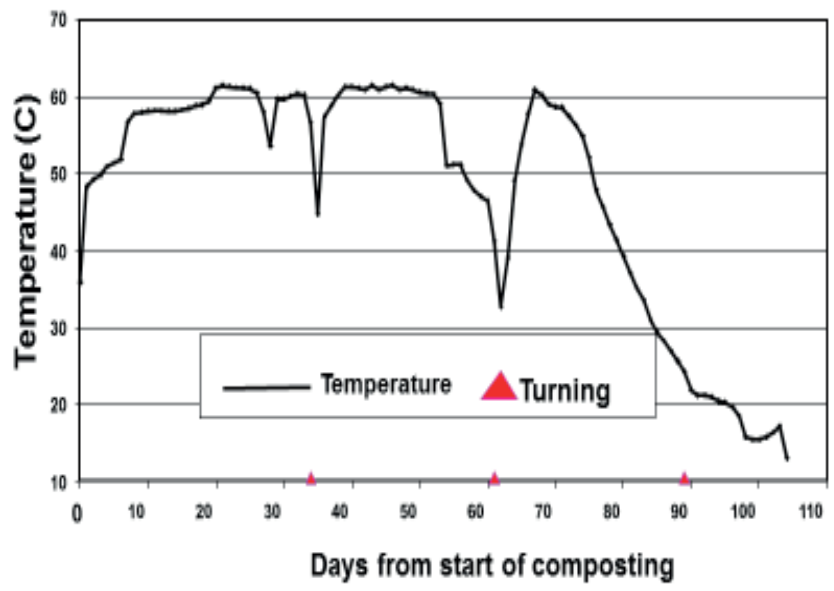

Figure 4.2 Evolution of the temperature in a controlled compost pile during a typical composting process (Graph: Michael Raviv).

The temperature level reached depends of the reactivity of the starting mixture and on the control means. Optimally, the temperature should reach $60-65^{\circ} \mathrm{C}$. For a better biological quality of the compost, a temperature as high as 70 or $80^{\circ} \mathrm{C}$ is not desirable. This happens when the starting mixture is too rich in $\mathrm{N}$ combined with sufficient oxygen and not enough moisture content. A very high temperature in the pile limits the diversity of the microorganisms in the composting material and decreases the decomposition rate. 
Under controlled conditions (e.g. when temperatures are measured daily and turnings are done in order to maintain the temperatures below a setpoint), the process is quite different. A typical optimal thermophilic temperature $\left(\mathrm{e} . \mathrm{g} .60^{\circ} \mathrm{C}\right.$ ) is maintained by frequent turnings (or aeration, in case of the forced aeration composting system). Under such conditions, mass extinction of thermophilic microorganisms does not occur, leading to a longer thermophilic phase (typically 6-8 weeks), a better control of pathogen and weed seeds and the avoidance of ashing. The result is a compost of higher quality. Turning ensures better homogeneity of the compost, by bringing outer, cooler layers into the core of the pile.

The elevation of the temperature during the composting process is essential to ensure the destruction of weeds and of pathogens that are usually present in the starting mixture (see chapter 5). For this to happen, the temperature has to reach at least $55^{\circ} \mathrm{C}$ during three weeks or $65^{\circ} \mathrm{C}$ during one week, and the compost pile has to be turned at least twice during this period.

An insufficient temperature can be observed when the starting mixture is too rich in carbon, too dry, too wet or when there is insufficient oxygen present in the pile. Attaining a sufficient temperature should not be a problem with correct management of the process.

The management of the moisture content in the pile is also an important factor that influences the evolution of the temperature to some extend (see below).

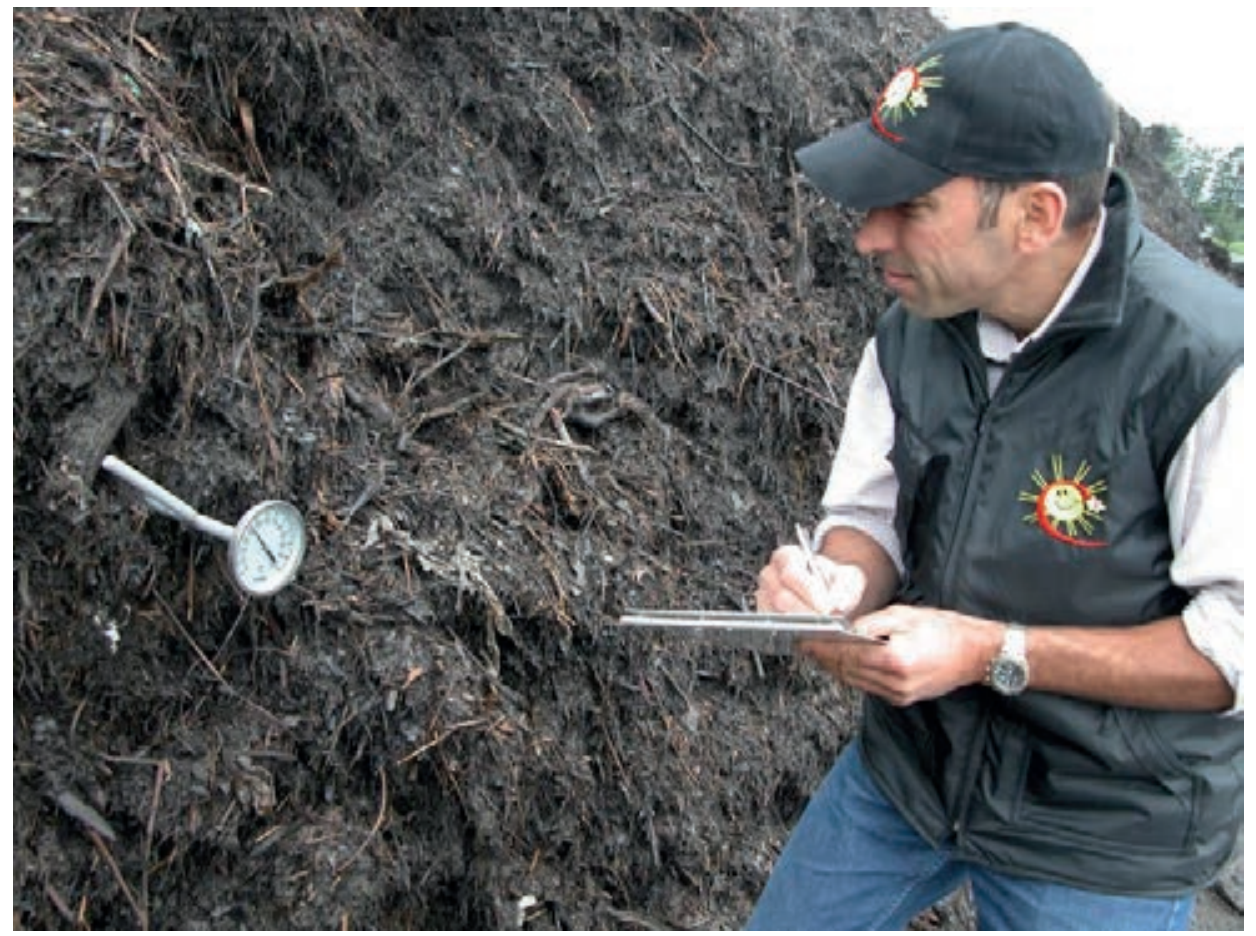

Figure 4.3 Temperature measurement is important to control the composting process.

The evolution of the temperature is a good indicator of the quality of the composting process. Normally, the temperature increases relatively rapidly at the start of the process, and then slowly decreases. After turning the compost pile, the temperature drops and immediately increases again. This is because the turning operation redistributes the intermediate decomposition molecules and optimizes the oxygen distribution in the pile, hence triggering the biological activity in the pile. The evolution of the average temperature is relatively steady if the evolution of the composting process is going well. An abrupt decrease in temperature is a sign that something is wrong in the process, such as insufficient or excess moisture, or the limited presence of available nitrogen. The evolution of the temperature has to be recorded periodically, preferably daily or at least three times per week. It is important to measure the temperature correctly: at the hot spot (at a depth of 40-50 cm, see Figure 3.3) at 3 to 10 spots of the pile (depending on the pile dimension). These data are important as they prove the correct natural hygienization of the compost (see chapter 5). For larger compost piles, thermometers (or preferably sensors connected to data loggers) should be inserted in the middle of the pile, at half the height. 


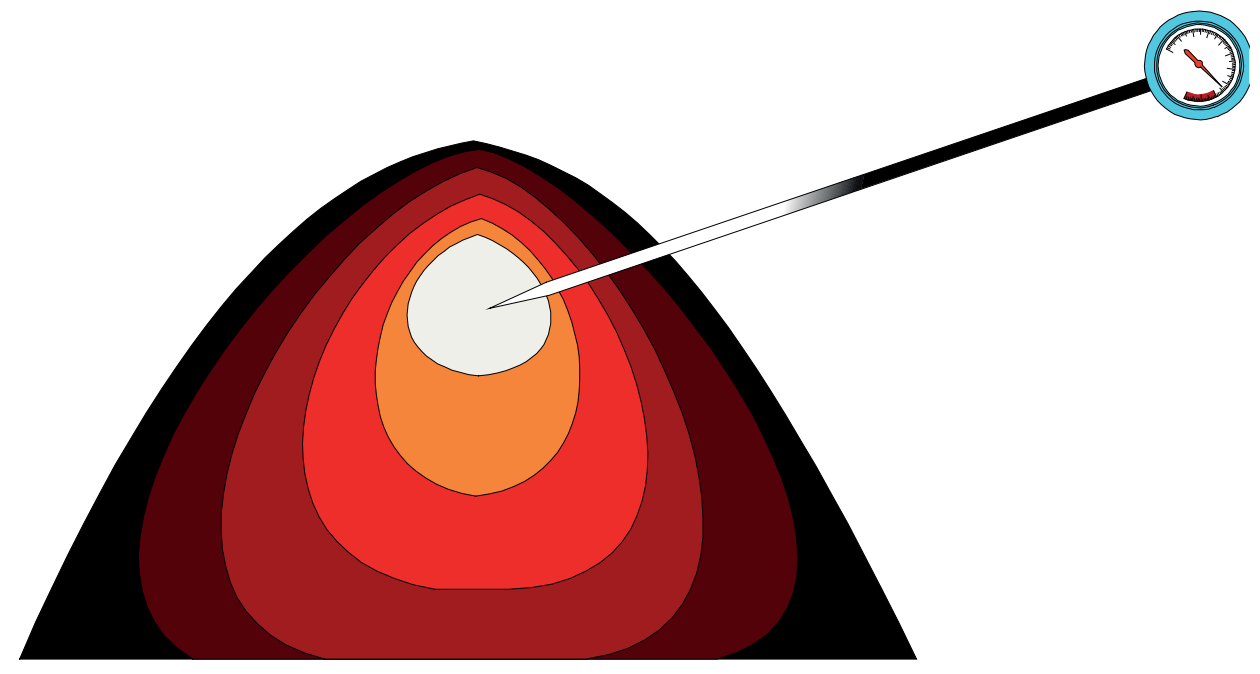

Figure 4.4 The temperature of the compost pile has to be measured at the central hot spot (Graph: Ulrich Galli).

The duration of the composting process is not relevant as a quality parameter. The complete process can take between 10 weeks and 6 months depending on the input material, the composting system and the intensity of process management.

\subsubsection{Moisture content}

As explained in Chapter 3, microorganisms are only active when sufficient moisture is available. Excessive moisture, on the other hand, can lead to undesirable anaerobic processes which can even arrest the composting process. Water evaporation from the pile is important to prevent excessive temperatures as well as optimizing microbial activity. The quantity of water needed to maintain optimal moisture in the compost pile varies during the process. Water evaporation is important because of the high temperature of the pile. This evaporation is enhanced by intensive compost turning or active aeration of the pile. Maintaining optimal moisture content is therefore crucial during this period. Later, during the curing phase, much less water is lost, and water oversupply can quickly lead to excessive high moisture levels in the compost.

To obtain a compost of homogenous quality, moisture distribution has to be homogenous in the pile. This is another reason for turning the compost pile periodically.

The moisture content of the external layer of the compost pile $(0-20 \mathrm{~cm})$ is generally different from that of the rest of the pile. Therefore, moisture content should be determined using test samples from inside the pile (typically 40-50 cm deep).

Optimal moisture content for the composting process roughly corresponds to a dry matter content of about $50 \%$. The moisture content can be estimated using the so-called fist test (Figure 4.5): take a handful of compost and squeeze it as strongly as possible between the fingers. If water flows out, the compost is too wet. Open the fingers. If the compost ball disintegrates itself, the compost is too dry. If the compost ball stays compact, the compost moisture is optimal.
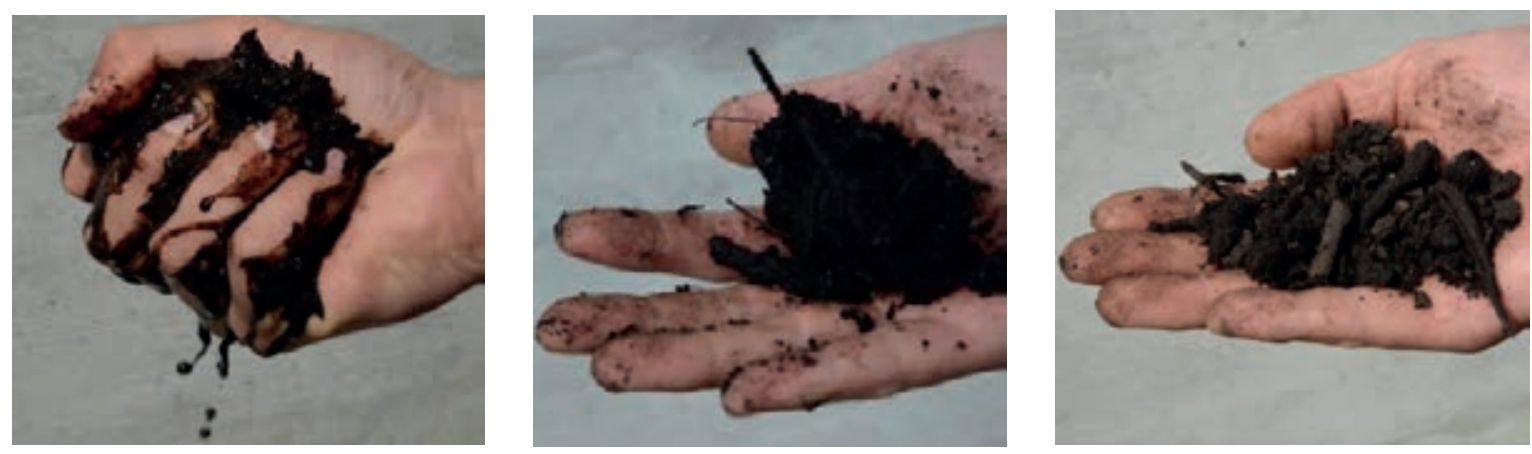

Figure 4.5 Fist test to control the humidity of compost during the composting process. From left to right: too wet, optimal, and too dry.

56 I Handbook for Composting and Compost Use in Organic Horticulture 


\subsubsection{Oxygen content}

To have an optimal composting process, the oxygen content in the atmosphere of the compost pile has to be at least 3 to $5 \%$. It is also important to pay attention to the distribution of the oxygen in the pile, making sure that each piece of material is supplied with enough oxygen. Here, it is particularly important to avoid the formation of clods using efficient compost turning; otherwise, anaerobic conditions can be present in these chunks. To be sure that the aerobic conditions are present in the whole pile, we recommend a measurement of the methane $\left(\mathrm{CH}_{4}\right.$ content within the pile - this can be carried out using a portable gas analyzer). The absence of $\mathrm{CH}_{4}$ is an indication of a homogenous distribution of oxygen in the pile.

The oxygen demand is much more important during the thermophilic phase of the composting process. Later, when the microbiological activity decreases, the oxygen demand decreases strongly and continues at a low level. It is important to constantly maintain a minimal level of oxygen in the compost to ensure high biological quality, including during the storage of the mature products.

\subsubsection{Available nitrogen}

The nitrogen $(\mathrm{N})$ in composts is mainly present as organic nitrogen, which is less available to plants. However, the greatest proportion of $\mathrm{N}$ taken up by plants is in the form of mineral- $\mathrm{N}$. Three forms of mineral nitrogen are relevant in compost: ammonia $\left(\mathrm{NH}_{4}-\mathrm{N}\right)$, nitrite $\left(\mathrm{NO}_{2}-\mathrm{N}\right)$ and nitrate $\left(\mathrm{NO}_{3}-\mathrm{N}\right)$. The concentration of these three forms is evaluated during the composting process (Figure 4.6, see also chapter 3 ).

$\mathrm{NH}_{4}-\mathrm{N}$ is the first form of mineralized nitrogen found in compost when the organic material is decomposed.

$\mathrm{NH}_{4}-\mathrm{N}$ is soluble in water and when the moisture content becomes too low, the $\mathrm{NH}_{4}-\mathrm{N}$ is lost as it will be formed into gaseous $\mathrm{NH}_{3}$ (ammonia).

$\mathrm{NO}_{3}-\mathrm{N}$. During the curing process, nitrification is ongoing and the $\mathrm{NH}_{4}-\mathrm{N}$ is transformed into $\mathrm{NO}_{3}-\mathrm{N}$. If oxygen starvation happens during the curing phase or the storage, bacteria can use the oxygen of $\mathrm{NO}_{3}$ and transform it back to nitrite $\left(\mathrm{NO}_{2}\right.$; toxic for the plants) or to nitrous oxide $\left(\mathrm{N}_{2} \mathrm{O}\right.$; strong greenhouse gas).

$\mathrm{NO}_{2}-\mathrm{N}$ is an intermediate, phytotoxic product arising during the nitrification. It can also be a result of the denitrification process by oxygen starvation at the end of the curing process or from compost storage.

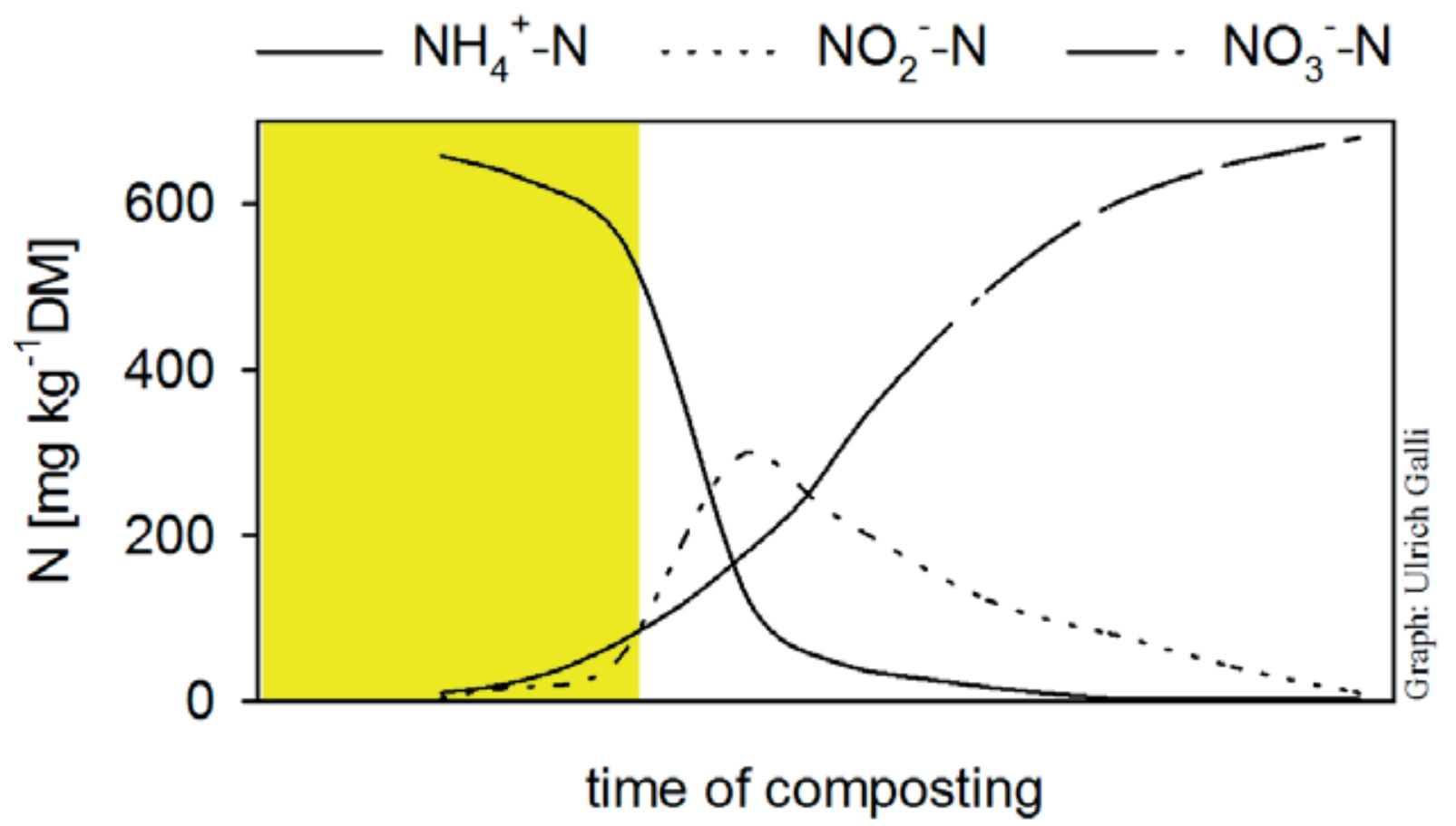

Figure 4.6 Evolution of the mineralized forms of nitrogen in the compost piles during the composting process (Graph: Ulrich Galli). 
If the composting mixture is carbon-rich or when the composting process is inappropriately managed (e.g. low moisture content), it is possible to find almost no mineral $\mathrm{N}$ in the compost. The $\mathrm{N}$ is immobilized in the microbial community or is lost as $\mathrm{NH}_{3}$. In this case, the composting process can become blocked because of lack of available $\mathrm{N}$. When such compost is applied, it is also possible that $\mathrm{N}$ immobilization happens in field, and the plant growth can then be inhibited if no other sources of nitrogen are added. So, the values of mineralized forms of $\mathrm{N}$ are essential parameters to management of the composting process on one hand and the identification of appropriate uses for compost products on the other.

$\mathrm{NH}_{4}-\mathrm{N}, \mathrm{NO}_{2}-\mathrm{N}$ and $\mathrm{NO}_{3}-\mathrm{N}$ can be easily analysed with different quick tests in $0.01 \mathrm{M} \mathrm{CaCl}_{2}$ or $\mathrm{KCl}$ compost extracts. These tests can be performed on site by the composting manager. The interpretation of the obtained measurements is described in Table 4.1. It is not the absolute individual values that are the most important, but the relationships between the different forms of mineralized nitrogen.

\section{Table 4.1}

Interpretation of the signification of the quantity of the different forms of mineralized nitrogen forms in compost.

\begin{tabular}{|c|c|c|c|}
\hline \multicolumn{3}{|c|}{ Presence of the $N_{\min }$ form ${ }^{1}$} & \multirow{2}{*}{ Interpretation } \\
\hline $\mathrm{NH}_{4}-\mathrm{N}$ & $\mathrm{NO}_{2}-\mathrm{N}$ & $\mathrm{NO}_{3}-\mathrm{N}$ & \\
\hline- & - & - & $\begin{array}{l}\text { No available } \mathrm{N} \text {. Mixture too rich in carbon, or all } \mathrm{NH}_{4}-\mathrm{N} \text { was lost because } \\
\text { of lack of moisture. If the compost is carbon rich: risk of nitrogen } \\
\text { immobilization in the field. Recommendation: mix some N-rich material to } \\
\text { the mixture (digestate, lawn, chicken litter, etc.). }\end{array}$ \\
\hline$++/+++$ & - & - & $\begin{array}{l}\text { Young compost (or digestate). Nitrification has still not started. } \\
\text { Recommendation: keep the mixture moist enough to avoid } \mathrm{NH}_{4}-\mathrm{N} \text { losses } \\
\text { and allow nitrification. }\end{array}$ \\
\hline$++/+++$ & ++ & $+/++$ & $\begin{array}{l}\text { Nitrification process starting. Recommendations: keep the mixture } \\
\text { sufficiently moist to avoid } \mathrm{NH}_{4}-\mathrm{N} \text { losses; make sure that the oxygen supply } \\
\text { to the mixture is constantly sufficient }\end{array}$ \\
\hline+ & $+/++$ & $++/+++$ & $\begin{array}{l}\text { Nitrification process is progressing. Recommendation: make sure that the } \\
\text { oxygen supply to the mixture is constantly sufficient }\end{array}$ \\
\hline- & - & $++/+++$ & $\begin{array}{l}\text { Nitrification process achieved. Recommendation: make sure that the } \\
\text { oxygen supply in the mixture is constantly sufficient Compost is mature and } \\
\text { ready to be used. }\end{array}$ \\
\hline- & $++/+++-$ & ++ & $\begin{array}{l}\text { Oxygen starvation problem. Recommendation: improved aeration of the } \\
\text { compost. }\end{array}$ \\
\hline
\end{tabular}

1 -: none (<10 mg N / kg DM); +: low quantity (10-50 mg N / kg DM); ++: medium quantity (50-200 mg N / kg DM); +++ : high quantity (> $200 \mathrm{mg} \mathrm{N} / \mathrm{kg} \mathrm{DM}$ )

\subsubsection{Maturity level}

Several parameters give information on the maturity level of the compost. Principally, mature compost is stable and biologically less active compared to a young one. This means that the temperature of the compost does not rise anymore after compost turning, and also that the respiratory activity is low. The $\mathrm{C} / \mathrm{N}$ ratio of mature compost is about 15 .

A good indicator for the maturity level of compost is the $\mathrm{NO}_{3}-\mathrm{N} / \mathrm{N}_{\min }$ ratio. As describe above, young compost contains mainly only $\mathrm{NH}_{4}$ as mineralized $\mathrm{N}$. Mature compost contains almost only $\mathrm{NO}_{3}$ as mineralized $\mathrm{N}$. Based on results of Swiss studies ${ }^{1,2}$, we recommend the use of the $\mathrm{NO}_{3}-\mathrm{N} / \mathrm{N}_{\min }$ ratio as a reliable maturity parameter. These analyses should be done just before using the compost, and shortly after sampling. In the Netherlands, the common test is based on Oxygen Uptake Rate $\left(\mathrm{OUR}^{6}\right)$. An even more accurate method to measure heat generation by the compost is through the use of microcalorimeter? 


\title{
4.2 Use of control measures
}

\author{
4.2.1 Maturity level and phytotoxicity
}

When the composting process is correct, different parameters indicate the maturity level of compost: the reduction of pile temperature, the reduction in oxygen consumption, and an odor progression from $\mathrm{NH}_{3}$ to an earthly smell similar to a forest soil. This is caused by geosmin, a compound produced by actinomycetes ${ }^{8}$. In addition to the observation of the compost with our own senses (odor, structure, etc.), two analyses of parameters can be recommended for the practice: the determination of the $\mathrm{NO}_{3}-\mathrm{N} / \mathrm{N}_{\min }-$ ratio (see 4.1.5) and the phytotoxicity test. The characterization of these two parameters can be easily performed at the compost plant itself, and the information gained is especially relevant for the practical use of the compost.

\subsubsection{NO3-N/Nmin-ratio}

As described above, the mineralized forms of $\mathrm{N}$ are evaluated during the curing process. Hence, the NO3-N/ $\mathrm{N}_{\min }$-ratio is a good indicator of the effective maturity of the compost, and gives important information about the possible application target of the compost. The value of this ratio is an important predictor of whether the compost will provide nitrogen to the plant or conversely, immobilize the nitrogen present in the soil. Using this value, plant growers can develop a strategy of nitrogen fertilization:

- $\underline{\mathrm{NO}}_{3}-\mathrm{N} / \mathrm{N}_{\min }-$ ratio < 0.2: young compost, with risk of nitrogen immobilization in the field if its carbon content is important (e.g. lignin rich compost). Not recommended for plants with high need for N. Can be used as mulch in some cases.

- $\mathrm{NO}_{3}-\mathrm{N} / \mathrm{N}_{\min }$-ratio between 0.2 and 0.8: compost is in curing phase. Can be used in field culture.

- $\mathrm{NO}_{3}-\mathrm{N} / \mathrm{N}_{\text {min }}-$ ratio > 0.8: mature compost. Can be used in substrates and planting holes.

-

\subsubsection{Phytotoxicity tests}

A high salt content in the composting mixture may cause phytotoxicity (see 4.2.1.6). In addition, in the first phase of the decomposition of organic material, other toxic compounds may form. As a result, young composts are initially phytotoxic. During the curing phase, these toxic molecules are transformed into harmless compounds and the compost becomes more compatible for the plants. However, if the curing phase or the storage is not optimally managed (mainly due to oxygen deficiency), toxic compounds can be formed and the compost becomes phytotoxic again. The degree of phytotoxicity depends also on the plant to be grown on the compostamended soil: some species are very sensitive, whereas others are less sensitive. For some plants, high salt content can also be a cause of phytotoxicity. Therefore, the best way to characterize the phytotoxicity risk is to perform tests using plants.

Simple tests can be done comparing germination rates of a given seed type in both compost and potting soil. Garden cress (Lepidium sativum) is considered as a very suitable plant to do this (Figure 4.7).
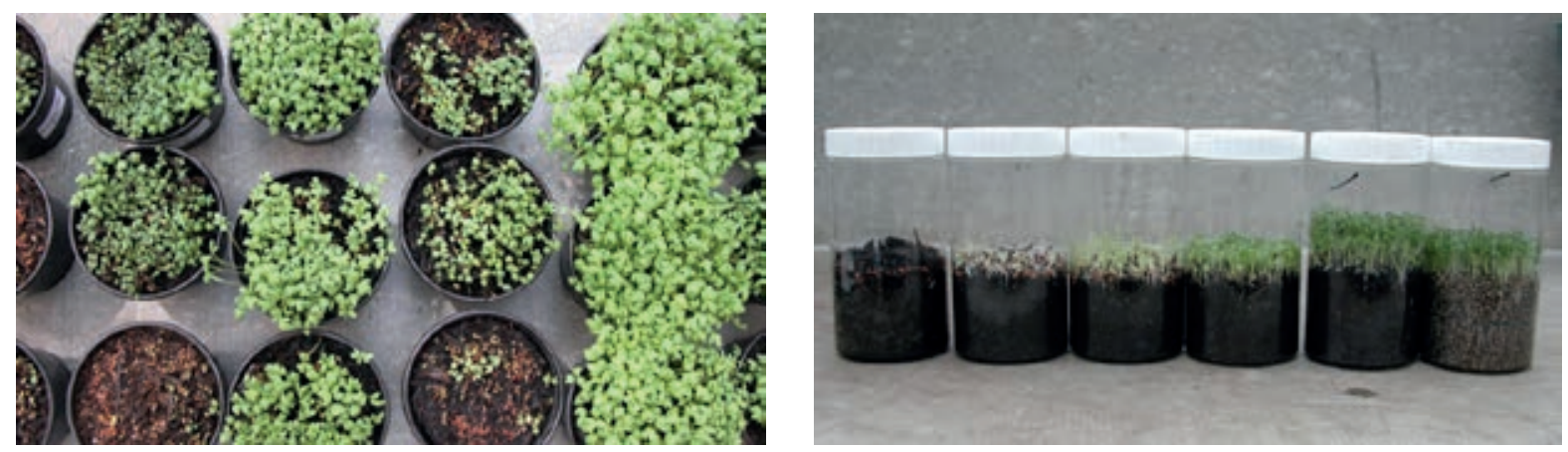

Figure 4.7 Phytotoxicity tests to assess the compatibility of composts with plants.

Left: open cress test. Right: closed cress test. 
- In the open cress test (the growth of cress in pots $(\varnothing 10 \mathrm{~cm})$ filled with compost is compared with its growth in potting soil), the cress is not really sensitive and a bad result (plant weight $<50 \%$ of those in potting soil) indicates an important phytotoxicity problem.

- In the closed cress test (PVC boxes (1 litre) are half-filled with compost potting soil, cress is sown in it, and then the boxes are closed hermetically; the length of the roots in compost and in potting soil is then compared). The test is very sensitive, and if the results are positive (roots length $>70 \%$ of those in potting soil), the compost can be used for all applications (also for substrate production).

In order to shorten the duration of the phytotoxicity test, while still exposing the plants to the compost itself and not an extract, a phytotoxicity test that was recently modified ${ }^{9}$ is proposed. This gives reliable results within 48 hours.

\subsubsection{Heavy metals}

Heavy metals are present in the environment and are also absorbed by the plants. The presence of a modest quantity of heavy metals in the composts is therefore acceptable. However, the quantity of heavy metals in the compost depends on the quality of the input material. For this reason, composting of municipal solid waste should only use source separated organic waste. The maximum permitted level of heavy metals in compost for organic use are indicated in Table 4.2.

Table 4.2

Maximum allowed heavy metals contents of compost for use in organic agriculture in Europe.

\begin{tabular}{ll} 
Heavy metal & Maximum value $[\mathrm{g} / \mathrm{t} \mathrm{DM}]$ \\
Lead $(\mathrm{Pb})$ & 45 \\
\hline Cadmium $(\mathrm{Cd})$ & 0.7 \\
\hline Copper $(\mathrm{Cu})$ & 70 \\
\hline Nickel $(\mathrm{Ni})$ & 25 \\
\hline Mercury $(\mathrm{Hg})$ & 0.4 \\
\hline Zinc $(\mathrm{Zn})$ & 200 \\
\hline Chrome $(\mathrm{Cr})$ & 70 \\
\hline Chrome (IV) & 0
\end{tabular}

Heavy metal level in compost should be periodically analyzed according to standard analysis methods recognized by the authorities (see chapter 2).

\subsubsection{Nutrient contents}

The nutrient content of the input materials can vary greatly. Woody materials are generally much less concentrated in nutrients than lignin-poor material. Consequently, the nutrient contents in different composts can vary by factor of 3 to 4 . So when using compost, it is essential to analyse the nutrient content of the specific compost to be able to calculate the nutrient balance, and not to use average values taken from the literature (see chapters 1 and 2).

\subsubsection{5 pH-value}

The $\mathrm{pH}$-value of compost is usually relatively high (7.2 to 8.5). The $\mathrm{pH}$-value is influenced by the composting process. At the start of the composting process, the $\mathrm{pH}$ is relatively low because of the presence of organic acids then, $\mathrm{pH}$ rises with the increase of the $\mathrm{NH}_{4}$-content. Young composts thus have a high $\mathrm{pH}$-value (above 8). During nitrification, the $\mathrm{pH}$-value decreases. Thus mature composts usually have $\mathrm{pH}$-values under 8 . Because of the dynamics of the $\mathrm{pH}$ value, $\mathrm{pH}$ has to be measured periodically.

Common composts have a $\mathrm{pH}$ above 7. Therefore, the use of compost is not appropriate for acidophilic plants like blueberries and Rhododendron. 
When using compost in plant growing media, it is possible to use elementary sulphur (S) to lower the $\mathrm{pH}$-value of the media. Another possibility is the use of a significant fraction of acidic feedstocks such as olive pomace, orange peel, etc.

\subsubsection{Salt content}

Like the nutrients, salt content can greatly vary between different composts. Salt content is largely influenced by the input material, but also by the composting process. The latter is the result of the mineralization of the organic matter and of the building up of the humus compounds.

Salt content can be a limiting factor, depending on the type of crop grown. Salt content is a generic term which covers a great number of substances. Some of these are not essential for the plants and can be harmful rather than useful, like $\mathrm{NaCl}$ (table salt). Other salts, like the mineralized forms of $\mathrm{N}$ are important for the growth of the plant. Not only is the salt quantity itself important, but also the quantities of plant relevant salts like $\mathrm{NH}_{4}-\mathrm{N}$ and $\mathrm{NO}_{3}-\mathrm{N}$.

An important point to consider when interpreting the salt content of compost is the extraction method used to determine it, as well as the units of measurement. Depending on the country, the water/compost ratio used to perform the compost extraction can vary greatly, and so the results obtained are not directly comparable. In some cases, the salinity is expressed as electrical conductivity in the extraction solution, and in other cases it is recalculated as $\mathrm{g} \mathrm{KCl}_{\text {equivalent }}$ per compost quantity (for example per $\mathrm{g} \mathrm{DM}$ ). This point needs to be absolutely considered when interpreting the salt content of the compost.

\subsubsection{Intensity of colour extract}

The colour intensity of compost water extract is important for the use of compost as a component in plant media. For example, if compost with a dark colour extract is used in a flower pot, there is a risk that can result in an undesirable coloration of the house wall or soil.

The water extract of young lignin-rich compost is dark, and its colour becomes lighter with increasing maturity. This is because the humus molecules present in young composts are small and soluble in water. During the maturation, microorganisms construct more complex humus molecules which are no longer soluble, thus making the extract lighter. The darkness of the extract of young compost also depends on the composition of the starting mixture.

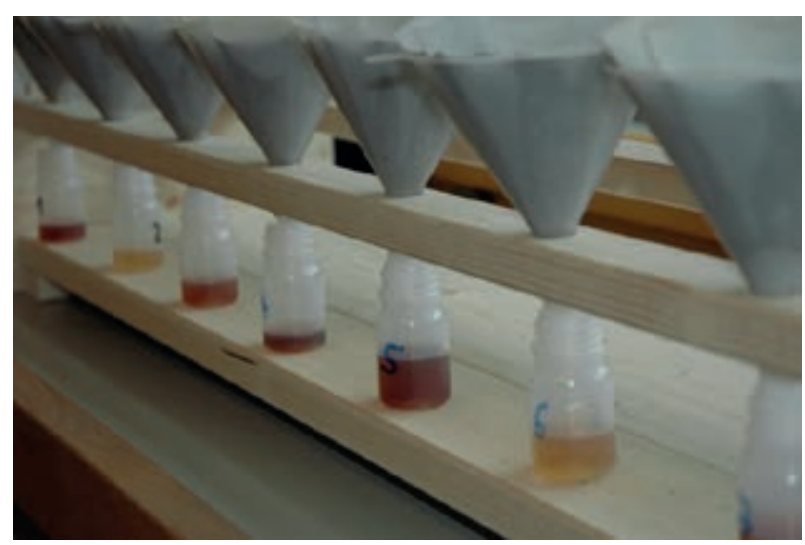

Figure 4.7 The colour of water extract can greatly vary between different composts. It can be a limiting factor for the production of culture media.

\subsubsection{Pathogens and weeds}

Input organic material can contain pathogens and weed seeds. However, these are destroyed by a well-managed composting process. It is absolutely crucial to be certain that these pathogens and weed seeds are effectively inactivated before using the compost to avoid all risk of contamination of the soil in which the compost is used. Three parameters are important for the natural sanitation of organic waste during the composting process: the temperature, the intermediate chemicals compounds resulting from the decomposition of the organic waste that are toxic to the pathogens, and the biological control of the pathogens by beneficial microorganisms. 
The presence of weed seeds in compost can be assessed with germination tests, although these tests can be rather labour-intensive. It is much more difficult to assess the absence of pathogens, because the number of the possible harmful organisms is high, and it is not possible to test for all of them. A pragmatic solution is to control the temperature evolution during the composting process, as well as to guarantee a sound operation management that avoids recontamination of the mature compost with infested fresh waste.

In conclusion, a compost which had a temperature $>55^{\circ} \mathrm{C}$ during at least three weeks or $>65^{\circ} \mathrm{C}$ during one week is to be considered harmless from a hygienic point of view providing the compost pile is mixed at least twice during this period thus ensuring every part of the material is exposed to the higher temperature area at least once. A compost producer has to manage a precise protocol of the composting process in order to prove that the composts are hygienically harmless.

\subsection{Conclusion}

Few control measures are needed for the production of quality compost, as well as for selecting the adapted compost and its application strategy. The control measures described above are relatively simple to implement and are cheap. To successfully produce quality compost it is crucial to perform these tests regularly and carry them out carefully according to the protocol (sampling method, sample timing, performance of analysis). This is the key to the correct interpretation of these compost quality parameters in order to choose the right compost for the intended use and the optimal application strategy.

\subsection{References}

1. Kupper, T, Fuchs, J.G. (2007).

Kompost und Gärgut in der Schweiz. Studie 1: Organische Schadstoffe in Kompost und Gärgut.

Studie 2: Auswirkungen von Kompost und Gärgut auf die Umwelt, die Bodenfruchtbarkeit sowie die Pflanzengesundheit. Umwelt-Wissen Nr. 0743. Bundesamt für Umwelt, Bern. $124 \mathrm{~S}$.

2. Fuchs, Jacques G., Berner, Alfred, Mayer, Jochen and Schleiss, Konrad (2014).

Concept for quality management to secure the benefits of composts use for soil and plants. Acta Horticulturae 1018: 603-609.

3. Whiteside, M.D., Garcia, M.O. and Treseder, K.K. (2012). Amino Acid uptake in arbuscular mycorrhizal plants. PLoS ONE 7(10):e47643, 2012.

4. Lesuffleur, F., Salon, C., Jeudy, C. and Cliquet, J.B. (2013).

Use of a 15N2 labelling technique to estimate exudation by white clover and transfer to companion ryegrass of symbiotically fixed N. Plant and Soil 369(1/2):187-197.

5. Paungfoo-Lonhienne, C., Thierry, G.A., Lonhienne, D., Rentsch, N., Robinson, M. et al. (2008). Plants can use protein as a nitrogen source without assistance from other organisms. Proc. National Acad. of Sciences of the USA. 105: 11, 4524-4529.

6. Geuijen, W. H. C. and Verhagen, J. B. G. M. (2014). Experiences with the OUR method EN 16087-1: interpretation of pressure curves and effect of method deviations. Acta Horticulturae 1034:255-261.

7. Medina, S., Raviv, M., Saadi, I. and Laor, Y. (2009). Methodological aspects of microcalorimetry used to assess the dynamics of microbial activity during composting. Bioresource Technology 100: 20, 4814-4820.

8. Li, H.F., Imai, T., Ukita, M., Sekine, M. and Higuchi, T. (2004). Compost stability assessment using a secondary metabolite: geosmin. Environmental Technology 25(11): 1305-1312.

9. Saadi, I., Raviv, M., Berkovich, S, Hanan, A., Aviani, I., and Laor, Y. (2013).

Fate of Soil-Applied Olive Mill Wastewater and Potential Phytotoxicity Assessed by Two Bioassay Methods. Journal of Environmental Quality 42 (6): 1791-1801. 


\title{
$5 \quad$ Hygienization Aspects of Composting
}

\author{
Aad Termorshuizen and Beatrix Alsanius
}

\section{In short:}

- Compost use in agriculture always brings about the risk of introducing plant and human pathogens.

- The backbone of the hygienization process consists of temperature, moisture content and chemical compounds formed during composting and activity of antagonists.

- Compost produced by proper composting, i.e. a process that produces high temperatures during a sufficiently long thermophilic phase can be applied safely.

- Farmers should invest in good relationships with compost producers.

One of the major reasons for composting organic residues is the inactivation of plant pathogens and weeds that are normally present in these residues and, if manure is included, the inactivation of animal and human pathogens as well. The hygienization process during composting is based on temperature, chemical compounds and biological mechanisms. The heat generated during the composting process has to be sufficiently high and the thermophilic phase long enough to inactivate the great majority of these potential risk organisms. Thus, good compost process management is a precondition to minimize the risks connected with these pathogens. In this chapter, we focus on these risks and how composters and farmers may deal with them. A good compost management strategy comprises:

- Correct starting mixture;

- Temperature increase;

- Sufficient duration of the thermophilic phase (e.g. 1 Week $>65^{\circ} \mathrm{C}$ );

- Turning of the compost during the thermophilic phase;

- Avoidance of contamination risk (general organization of the work place);

- Proper storage of the mature compost.

For both the producers' and growers' sake, the process should be monitored and registered in a process protocol (dates of adding different input material, temperature profile in time, turning dates, dates for addition of water and water quality data).

The fate of pathogens during composting is described in several review articles $3,7,9$. We therefore focus more on the general approach composters can take to minimize phytohygienic problems.

\subsection{Fate of pathogens during composting}

The backbone of the hygienization process is a sufficiently high temperature linked with moisture content, $\mathrm{pH}$, toxin and antibiotics formation as well as active antagonists ${ }^{2}$. Organisms posing a risk are pathogens capable of withstanding such conditions. Pathogens occur very commonly in feedstock organic residues, but the great majority, including pathogens of shoots and leaves (airborne pathogens), is inactivated during the thermophilic phase?. The short persistence of these heat-sensitive pathogens can be explained by leakage of nutrients through the thin cell walls. In addition, these thin cell walls are highly susceptible to attack by predators and antagonists. These mechanisms are also acvtive during the preheating and maturation phases of composting; but it is mainly the high temperatures prevailing during the heat phase of composting that inactivate most of the airborne pathogens ${ }^{12}$.

Additional phytosanitary risks include some highly persistent soil-borne pathogens (see Table 5.1 for examples) along with animal and human (Table 5.2) pathogens ${ }^{7}$. Some of them are completely inactivated during proper composting while others may survive the composting process. On first sight, this renders the use of compost as too risky, but as we will show, these risks can be dealt with properly. 
Generally, pathogens that are able to survive composting temperatures of $>60^{\circ} \mathrm{C}$ can be considered as risk pathogens. The mere existence of risk pathogens does not mean that the use of compost leads to phytosanitary problems. The likelihood of phytosanitary problems occurring has to be based on local conditions, mainly: The likelihood of occurrence of risk pathogens in the feedstock organic matter and the intended application of the mature compost ${ }^{9}$; in addition, for organisms pathogenic to humans, the mechanisms responsible for provoking infections as well as the infectious doses also need to be taken into account.

Cardinal points for selected human pathogens that may be transmitted by compost and probabilities for their inactivation during composting are presented in Table 5.3. However, their survival may also be improved in response to the matrix ${ }^{1}$. Feeding regime and the roughage type of the feed may affect the survival and transmission of human pathogens to vegetables; but survival patterns are pathogen dependent ${ }^{6}$. Also, heat shock treatment of E. coli 0157:H7, Listeria monocytogenes and Salmonella spp. for one hour at $47.5^{\circ} \mathrm{C}$ enabled their survival at temperatures above temperature maximum ${ }^{8}$.

Thus, the presence of risk pathogens at a given location is context-dependent: the occurrence of risk pathogens is region-dependent; the pre-treatment of residues from the food or feed industry can be factory-dependent; and composting conditions will be composter-dependent. Many pathogens are host-dependent, thus proper rotation of crops can solve this problem. Quarantine pathogens (see e.g. www.eppo.org) have a special status, and handling protocols are usually enforced by law. These may include the possibility of composting infected residues.

\subsection{Risk of pathogens and weeds present in residues offered for composting}

Phytosanitary risks are absent if the incoming organic material does not contain any pathogens or weeds at all. This is not normally the case as airborne pathogens and weeds occur nearly everywhere, and some persistent soil-borne pathogens are also common or even very common, such as the wilt pathogen Verticillium dahliae (occurring in e.g. chrysanthemum) and Rhizoctonia solani (in e.g. lettuce). A compost producer who is not aware of the presence of these pathogens in a particular batch of residues will run into problems. Therefore, a worstcase scenario, that assumes the presence of regionally common soil-borne pathogens in a given batch, would need to be followed. This worst-case scenario can then be based on the composition of the incoming materials, which is normally known by the compost producer. For example, if woody materials or grass clippings enter the composting plant, the composter will know that only a few low-risk pathogens can be present, while in the case of e.g. potato residues a whole arsenal of intermediate to high risk pathogens can be present. Therefore, potato residues from the processing industry are not offered for composting in the Netherlands unless they have been cooked. On the other hand, tomato residues that are very common in Israel frequently serve as feedstock for composting due to their strong capacity to suppress several plant pathogens ${ }^{10}$ (see chapter 6 ). The common Fusarium oxysporum may well occur on tomato residues and is rather heat-tolerant (Table 5.1) and therefore, high-quality composting is essential.

The main entry for human pathogens into feedstock material occurs through the addition of animal wastes. The spectrum of potential zoonotic organisms differs between different farm animals (Table 5.2) and also depends on national guidelines. For example, input of organic wastes from animal farms retrieved from conventional husbandry may be added to composts used in organic horticulture in some countries (e.g. in Switzerland).

The identification of sanitary risks of composting is a function of residue pretreatment. If untreated risk residues have to be dealt with, there are three options:

- Do not allow these into the composting process,

- Sell composts from these residues to non-risk applications or

- Perform an additional treatment to inactivate the pathogens. 
The latter option is expensive and economically and environmentally unviable. Owners of such residues may also consider other applications such as the generation of biogas but then the fate of pathogens in the remaining digestate should be considered, as well ${ }^{11}$ (see also chapter 7).

Pathogens without quarantine status that appear on lists of persistent, heat-tolerant pathogens, do not necessarily pose risks. To decide about this, detailed knowledge of the ecology of pathogens and of the local farming situation is important for risk assessment of the input material. Questions to be asked in this context are

- What are the cardinal points for inactivation?

- How is the pathogen transferred? Is it free-living or transferred by a vector?

- What is the biology of the vector?

Some issues on risk plant pathogens are illustrated in Table 5.1.

European legislation (EG 1069/2009; EG 1774/2002; EU 142/2011) is clear with respect to appropriate animal wastes or by-products introduced into compost. In the final product, Salmonella may not be detected in any sample and the average number of viable counts for E.coli or Enterococcaceae isolated from five representative samples shall not exceed $1000 \mathrm{CFU}$; of these only one of the five samples may have 1000-5000 colony-forming units (CFU). Reference to $E$. coli in such control programs stands for the organism as an indicator organism and not for pathogenic serotypes of $E$. coli. The presence of enterohaemorrhagic $E$. coli is not acceptable due to its very low infectious dose ( $<100$ cells). As human pathogens may be unevenly distributed in the compost, compost producers need to be careful about the load of contamination in the animal based raw input material, reflect on their procedure to obtain representative samples, and reflect on the meaning of a negative result.

\subsection{Quality of the composting procedure}

Improper composting techniques may also contribute to a failure to inactivate pathogens, the most important being:

- Improper or infrequent turning of the compost.

- The margins of the compost may not be exposed to heat. Therefore, compost turning has to be done by trained personnel so as to ensure that the organic material situated at the margin of the compost heap is placed in the centre after turning and exposed to high temperatures.

- Improper use of machines.

- Shovels should not move from feedstock residues to mature compost as the mature compost can then become contaminated with pathogens. This is especially a risk for small-scale composters who may have only a single shovel available. In that case machine cleaning when moving from mature compost to untreated organic residues is essential.

- Recolonization of mature compost with pathogens.

- This risk increases with the storage duration of the compost and especially when it is stored outdoors, where notably animal pathogens could enter the compost from bird visits. Weed seeds can also infest such open piles.

Composting can be done at large or small scale (Table 5.4). Large-scale composting is usually done by professional compost producers, and small-scale composting usually by the farmers themselves or by farmers groups such as Kibbutzim in Israel. Large-scale compost producers usually have good control on the process conditions, but their control on the quality of the incoming materials is limited. Their preference to sell the compost as early as possible may also have a negative effect on its end-quality. On the other hand, in smallscale composting, control on the process conditions may be more limited, but there is a better control of the incoming materials. If farmers use the compost they produced themselves only on their own fields, they will not import new pathogens from elsewhere. There is, however, a possibility of spreading the farm's own pathogens over multiple fields, which reduces the phytosanitary effect of rotation on soil-borne pathogens. 


\subsection{Conclusion}

On first sight, it seems straightforward to reject any residue for composting if there is even only a tiny phytosanitary risk. However, this is an unnecessarily cautious approach, possibly rendering most, if not all, residues unfit for composting. This is therefore an unwanted approach, since application of compost is one of the few possibilities for management of agronomic soil quality. As we explained here, most risks can be dealt with, providing a proper composting procedure has been followed. In many cases apparent risks may be absent, e.g. if the pathogen of interest is not occurring in a certain region, or if it is not present in the feedstocks. It is, therefore, of importance to consider the real existing risks and to have a clear plan for their management. An individual farmer has to weigh the pros and cons of own home-composting against those of professional, largescale composters (Table 5.4). If compost is to be obtained from the latter, it is important that farmers build a good relationship with composters.

\section{Table 5.1}

Examples of some (potential) risk plant pathogens. Instead of attempting to present a full list of pathogens, we would rather like to make the point here that reasoning about the phytosanitary risks of allowing certain residues for composting is context-dependent. An longer list of potential risk pathogens can be found in (7).

\begin{tabular}{|c|c|c|c|c|}
\hline Organism & Host & Remarks & Approach & References \\
\hline $\begin{array}{l}\text { Cucumber Green } \\
\text { Mottle Mosaic Virus } \\
\text { (CGMMV) }\end{array}$ & $\begin{array}{l}\text { cucumber, (water) } \\
\text { melon }\end{array}$ & $\begin{array}{l}\text { heat-resistant, } \\
\text { persistent in soil and } \\
\text { contact-transmitted }\end{array}$ & $\begin{array}{l}\text { risk material not } \\
\text { to be applied in } \\
\text { cucumber/melon } \\
\text { cropping systems }\end{array}$ & 13 \\
\hline Fusarium oxysporum & $\begin{array}{l}\text { various, including } \\
\text { tomato and basil }\end{array}$ & $\begin{array}{l}\text { inactivation } \\
\text { temperature about } \\
60{ }^{\circ} \mathrm{C}\end{array}$ & $\begin{array}{l}\text { composting } \\
\text { conditions are crucial }\end{array}$ & 14 \\
\hline $\begin{array}{l}\text { Olpidium brassicae, } \\
\text { vectoring two viruses }\end{array}$ & lettuce, cucumber & $\begin{array}{l}\text { inactivation } \\
\text { temperature } 53^{\circ} \mathrm{C} \\
(3 \mathrm{wk})\end{array}$ & $\begin{array}{l}\text { problematic only if } \\
\text { belowground plant } \\
\text { tissues are offered } \\
\text { for composting, e.g. } \\
\text { bulb materials. }\end{array}$ & 15 \\
\hline $\begin{array}{l}\text { Tobacco Rattle Virus } \\
\text { (TRV) }\end{array}$ & various & highly heat resistant & $\begin{array}{l}\text { considered } \\
\text { unproblematic as it } \\
\text { is vectored by heat- } \\
\text { sensitive nematodes }\end{array}$ & 2 \\
\hline $\begin{array}{l}\text { Tomato Mosaic Virus } \\
\text { (TMV), Tobacco } \\
\text { Mosaic Virus (ToMV) }\end{array}$ & various & heat resistant & $\begin{array}{l}\text { heat resistant, but } \\
\text { probably sufficiently } \\
\text { reduced during } \\
\text { composting }\end{array}$ & 16,17 \\
\hline Verticillium dahliae & $\begin{array}{l}\text { many, including } \\
\text { chrysanthemum }\end{array}$ & $\begin{array}{l}\text { heat-sensitive; } \\
\text { however common in } \\
\text { temperate regions } \\
\text { and able to cause } \\
\text { disease at low levels } \\
\text { of inoculum }\end{array}$ & $\begin{array}{l}\text { avoid bulk } \\
\text { feedstocks from } \\
\text { Verticillium- } \\
\text { contaminated } \\
\text { residues }\end{array}$ & 2 \\
\hline
\end{tabular}


Table 5.2

Dominant microbial hazards introduced through animal wastes (4).

\begin{tabular}{llll} 
Cattle & Pig & Chicken & Sheep \\
Salmonella & & & \\
\hline $\begin{array}{l}\text { Shiga-toxin producing } E . \\
\text { coli }\end{array}$ & Salmonella spp. & Campylobacter spp. & $\begin{array}{l}\text { Shiga-toxin producing E. } \\
\text { coli }\end{array}$ \\
\hline Listeria monocytogenes & Campylobacter spp. & Salmonella spp. & \\
\hline Campylobacter jejuni & Yersinia enterocolitica & ESBL \\
\hline & ESBL $^{1}$ & \\
\hline
\end{tabular}

$1 \mathrm{ESBL}=$ extended spectrum betalactamase-producing bacteria.

\section{Table 5.3}

Cardinal points for temperature, $\mathrm{pH}$ and water availability of some human pathogenic bacteria and probability of their inactivation during composting. Ranges may vary in relation to the matrix used. Figures for cardinal points and for probability of inactivation have been extracted from (1) and literature therein and from (5), respectively.

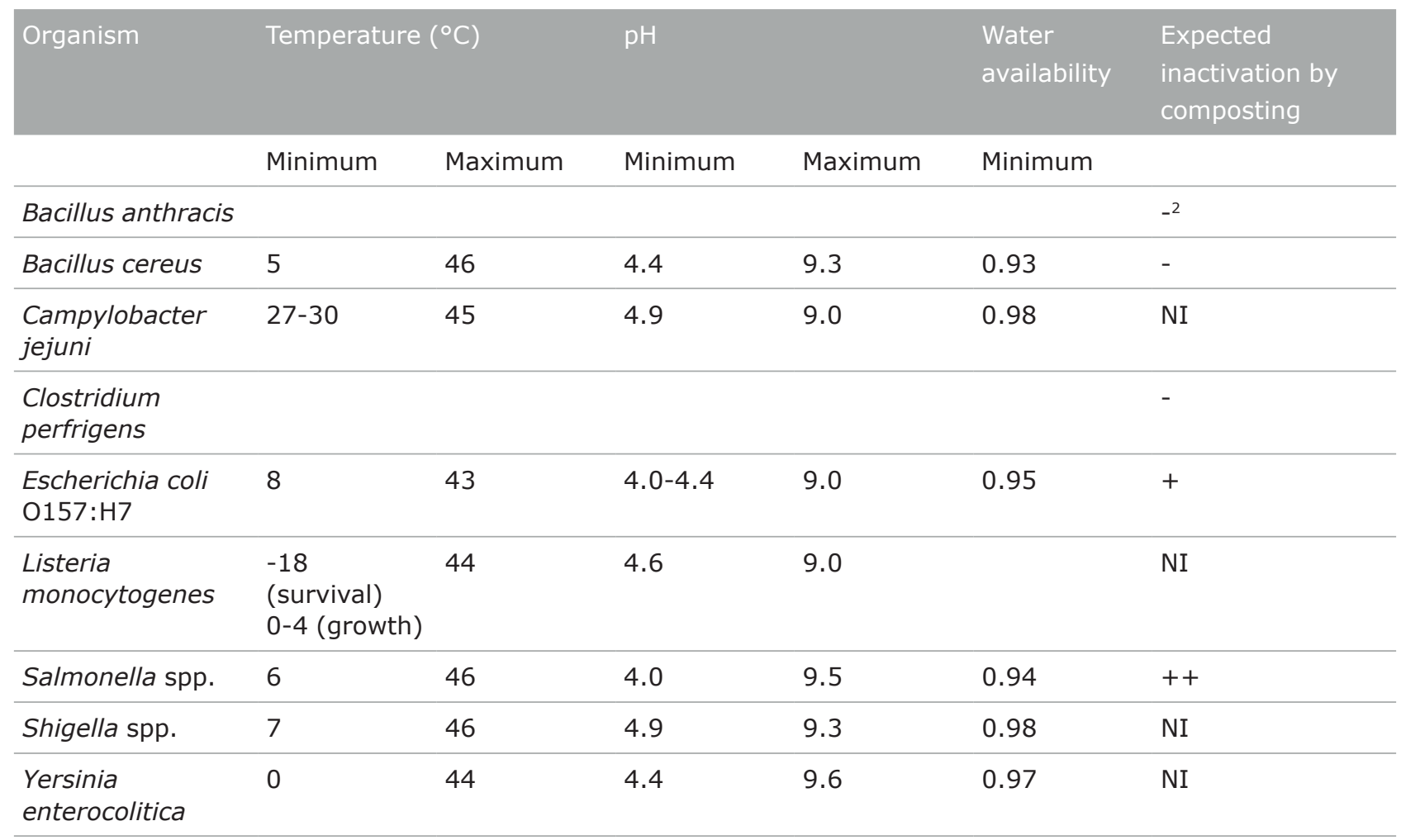

1 reprinted with permission of Elsevier.

$2++$ : total inactivation; +: inactivation; -: survival; (PI): no information on process but predicted inactivation of pathogen; (-) no information found, but predicted survival of pathogen, NI: no information found 


\section{Table 5.4}

Pros and cons of small-scale composting by individual farmers against large-scale composting by professional compost producers.

\begin{tabular}{llll}
$\begin{array}{l}\text { Scale of compost } \\
\text { producer }\end{array}$ & $\begin{array}{l}\text { Monitoring of } \\
\text { the composting } \\
\text { process }\end{array}$ & Pathogen presence in the to-be-composted material & $\begin{array}{l}\text { Feedstock (e.g. } \\
\text { manures) }\end{array}$ \\
\hline Large-scale & $\begin{array}{l}\text { generally high } \\
\text { standards }\end{array}$ & generally more pathogen species & better availability \\
\hline Small-scale & $\begin{array}{l}\text { varying from } \\
\text { low to high } \\
\text { standards }\end{array}$ & $\begin{array}{l}\text { generally less pathogen species; but higher risk of } \\
\text { introducing high quantities of pathogens occurring on } \\
\text { crops grown by the farmer }\end{array}$ & lower availability \\
\hline
\end{tabular}

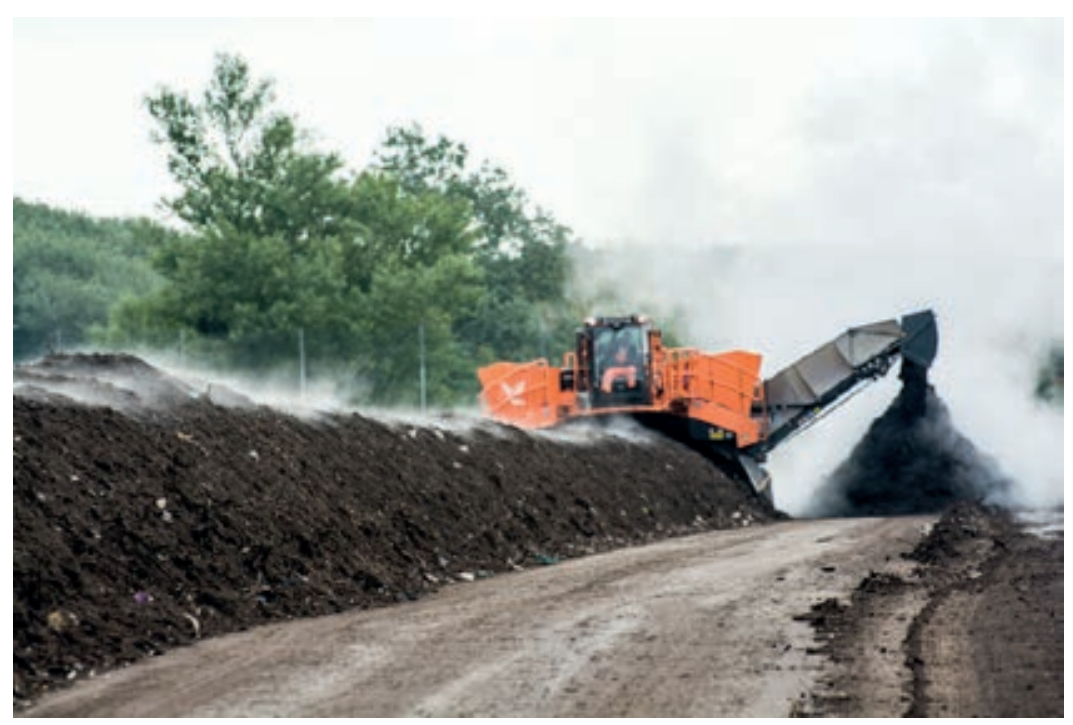

Figure 5.1 Machinery can cause contamination if they move directly from handling fresh residues to cured compost; this bad practice is not shown in this illustration, though. Photo: Paula van Ommen.

\subsection{References}

1. Alsanius, B. W., Dorais, M., Doyle, O., Oancea, F., and Spadaro, D. (2015).

Potential food hazards from organic greenhouse production. Scientia Horticulturae, submitted.

2. Bollen, G. J., and Volker, D. (1996).

Phytohygienic aspects of composting. Pages 233-246 in: Science of Composting, M. Bartoldi, P. Sequi, B. Lemmes and T. Papi, eds.

3. Bollen, G. J., Volker, D., and Wijnen, A. P. (1989).

Inactivation of soil-borne plant pathogens during small-scale composting of crop residues. Netherlands Journal of Plant Pathology 95:19-30.

4. Dorais, M., and Alsanius, B. W. (2015).

Advances and trends in organic fruit and vegetable farming research. Horticultural Reviews 43:185-268.

5. Franke-Whittle, I., and Insam, H. (2013).

Treatment alternatives of slaughterhouse wastes, and their effect on the inactivation of different pathogens: A review. Critical Reviews in Microbiology, 2013; 39(2): 39 (2):139-151.

6. Franz, E., van Diepeningen, A. D., de Vos, O. J., and van Bruggen, A. H. C. (2005).

Effects of cattle feeding regimen and soil management type on the fate of Escherichia coli O157:H7 and Salmonella enterica serovar Typhimurium in manure, manure-Amended Soil, and lettuce. Applied and Environmental Microbiology 71 (10):6165-6174. 
7. Noble, R., and Roberts, S. J. (2004).

Eradication of plant pathogens and nematodes during composting: a review. Plant Pathology 53:548-568.

8. Singh, R., Jiang, X., and Luo, F. (2010).

Thermal inactivation of heat-shocked Escherichia coli O157:H7, Salmonella, and Listeria monocytogenes in dairy compost. Journal of Food Protection 73 (9):1633-1640.

9. Termorshuizen, A. J., Blok, W. J., and van Rijn, E. (2005).

Phytosanitary risk assessment of composts. Compost Science and Utilization 13: 108-115.

10. Yogev, A., Raviv, M., Hadar, Y., Cohen, R., and Katan, J. (2006).

Plant waste-based composts suppressive to diseases caused by pathogenic Fusarium oxysporum.

European Journal of Plant Pathology 116:267-278.

11. Termorshuizen, A.J., Volker, D., Blok, W.J., ten Brummeler, E., Hartog, B.J., Janse, J.D., Knol, W., Wenneker, M. (2003).

Survival of human and plant pathogens during anaerobic mesophilic digestion of vegetable, fruit, and garden waste. European Journal of Soil Biology 39: 165-171.

12. Raviv, M., Krassnovsky, A., Kritzman, G., and Kirshner, B. (2011).

Minimizing the risk of bacterial canker spread through plant residue composting. Acta Horticulturae 915 : 151-156.

13. Lecoq, H. (1988).

Cucumber green mottle mosaic virus (CGMMV). In I.M. Smith, J. Dunez, R.A. Lelliott, D.H. Phillips, S.A. Archer (eds.), European Handbook of Plant Diseases, Blackwell Scientific, p. 52.

14. Bollen, G.J. (1985).

Lethal temperatures of soil fungi. In C.A. Parker, A.D. Rovira, K.J. Moore, P.T.W. Wong (eds.), Ecology and management of soilborne plant pathogens. APS Press, Minnessota, USA, pp. 191-193.

15. Asjes, C.J., and Blom-Barnhoorn, G.J. (2002).

Control of spread of augusta disease caused by tobacco necrosis virus in tulip by composting residual waste of small bulbs, tunics, roots and soil debris. Acta Horticulturae 570: 283-286.

16. Avgelis, A.D., and Manios, V.I. (1989).

Elimination of tomato mosaic virus by composting tomato residues. Netherlands Journal of Plant Pathology 95: 167-170.

17. Ryckeboer, J., Cops, S., and Coosemans, J. (2002).

The fate of plant pathogens and seeds during anaerobic digestion and aerobic composting of source separated household wastes. Compost Science and Utilization 10: 204-216. 
70 I Handbook for Composting and Compost Use in Organic Horticulture 


\title{
6 Disease suppression by compost
}

\author{
Soraya C. França and Andre W.G. van der Wurff
}

\section{In short}

- Disease suppressiveness is when a susceptible crop stays healthy or becomes only slightly diseased when a certain pathogen is present.

- A bioassay is commonly used to measure the level of suppressiveness.

- Almost all soils have some degree of suppressiveness in relation to soil-borne diseases, including soils in greenhouse horticulture.

- Although soil physical and chemical properties can play a direct role in disease suppressiveness, they often act indirectly by modulating soil organisms.

- Besides improving soil physical and nutritional condition, compost can particularly help to increase the level of disease suppressiveness of soil.

- The effect of compost has been intensively studied on Rhizoctonia solani and several species of Fusarium, Verticillium, Pythium and Phytophthora.

- The effect of compost on disease suppressiveness is predominantly biological, i.e., it usually involves the activity of microorganisms in soil/substrate and plant roots.

- Compost can also affect disease suppressiveness by changing the physical and chemical properties of soil and influencing the nutritional status of plants.

\subsection{Introduction}

\subsubsection{What is disease suppressiveness of soil?}

Suppressiveness is a condition of soil in which a susceptible crop stays healthy or becomes only slightly diseased in the presence of a certain pathogen under favourable environmental conditions for disease development ${ }^{1}$. In a conducive soil, the same crop would succumb to the disease caused by the pathogen ${ }^{1}$. The concept of suppressiveness is also applicable to growing media (substrates), i.e., substrates can be conducive or suppressive to diseases.

\subsubsection{How can we recognize a suppressive soil?}

A bioassay is often used to evaluate the status of disease suppressiveness of a soil. The bioassay consists of a pathogen, a susceptible host plant and the soil (or substrate) of interest. A susceptible crop is grown in the infested soil and disease development is evaluated (Figure 1). Usually, a well-documented conducive soil or substrate is used as a reference, but this depends on the goals. For example, if the disease suppressive characteristics of a compost are to be studied, the usual reference is a soil without addition of compost. If disease development in the plants is less than disease development in the reference, the soil is considered disease suppressive. If the disease development is equally fast or even faster, we consider the soil as disease conducive $^{2}$. When different soils are compared, different levels of suppressiveness may be detected: from very conducive to very suppressive. 


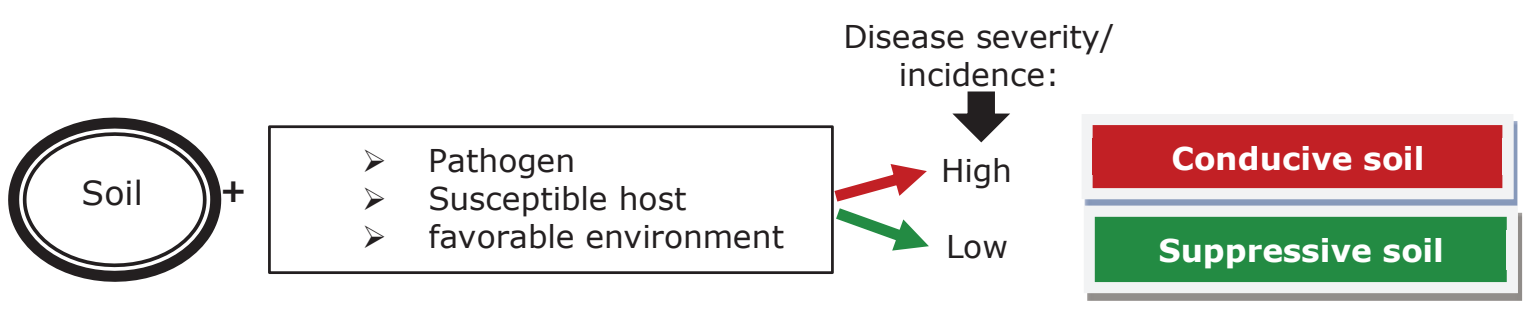

Figure 6.1 Bioassay to detect suppressiveness to a soil-borne disease.

\subsubsection{Where can we find suppressive soils?}

Almost all soils have some degree of suppressiveness to soil-borne diseases. Disease suppressiveness is a phenomenon that usually varies for different pathogens, with a specific component (e.g. a certain antagonist only affecting a certain pathogen) and a non-specific (general) component (i.e. the status of competitiveness of the whole microbial community in the soil or substrate ${ }^{2}$. In some soils, the levels of suppressiveness to specific diseases may be very high and stable. For example, some soils in the Châteaurenard region of France and the Salinas Valley of California, USA, are suppressive to Fusarium wilt ${ }^{2,3}$. However, such a very high and stable level of disease suppression occurs only exceptionally. At the other end of the spectrum, steam-sterilized soils are very well-known for their disease-conduciveness. In horticulture, such effects of steam sterilization are important as pathogens may easily recolonize steamed soil from, e.g., contaminated irrigation water, plant material or infested subsoil.

Recently, soils from a range of greenhouses of organic growers of tomato, sweet peppers and ornamentals in the Netherlands were compared and a high variation in suppressiveness to diseases caused by Pythium and rootknot nematodes was found ${ }^{4}$. Since cultural practices affect soil suppressive capacity, the bioassay as described above may give different results depending on the timing of soil collection. The spatial and temporal dynamics of disease suppressiveness in soils are not well known.

\subsubsection{How can we increase disease suppressiveness?}

Practices that stimulate biological activity have the potential to enhance suppressiveness (Figure 2). Although soil physical and chemicals properties can play a direct role in suppressiveness, they often act indirectly by modulating soil organisms.

A soil may become more suppressive when certain organic amendments such as mature compost (already proven as suppressive) and biological control agents (BCAs) are applied alone or in combination. The use of compost is one of the most frequently recommended practices for increasing suppressiveness to diseases. Practices that kill most soil organisms, such as soil fumigation and steaming, decrease suppressiveness (Figure 2). Interestingly, soil solarisation kills important pathogens, but at the same time stimulates beneficial organisms, often increasing suppressiveness ${ }^{5}$. Compost is particularly useful when applied immediately after chemical disinfestations or steaming. By restoring suppressiveness, compost application avoids quick reinfestation of the soil by pathogens. 


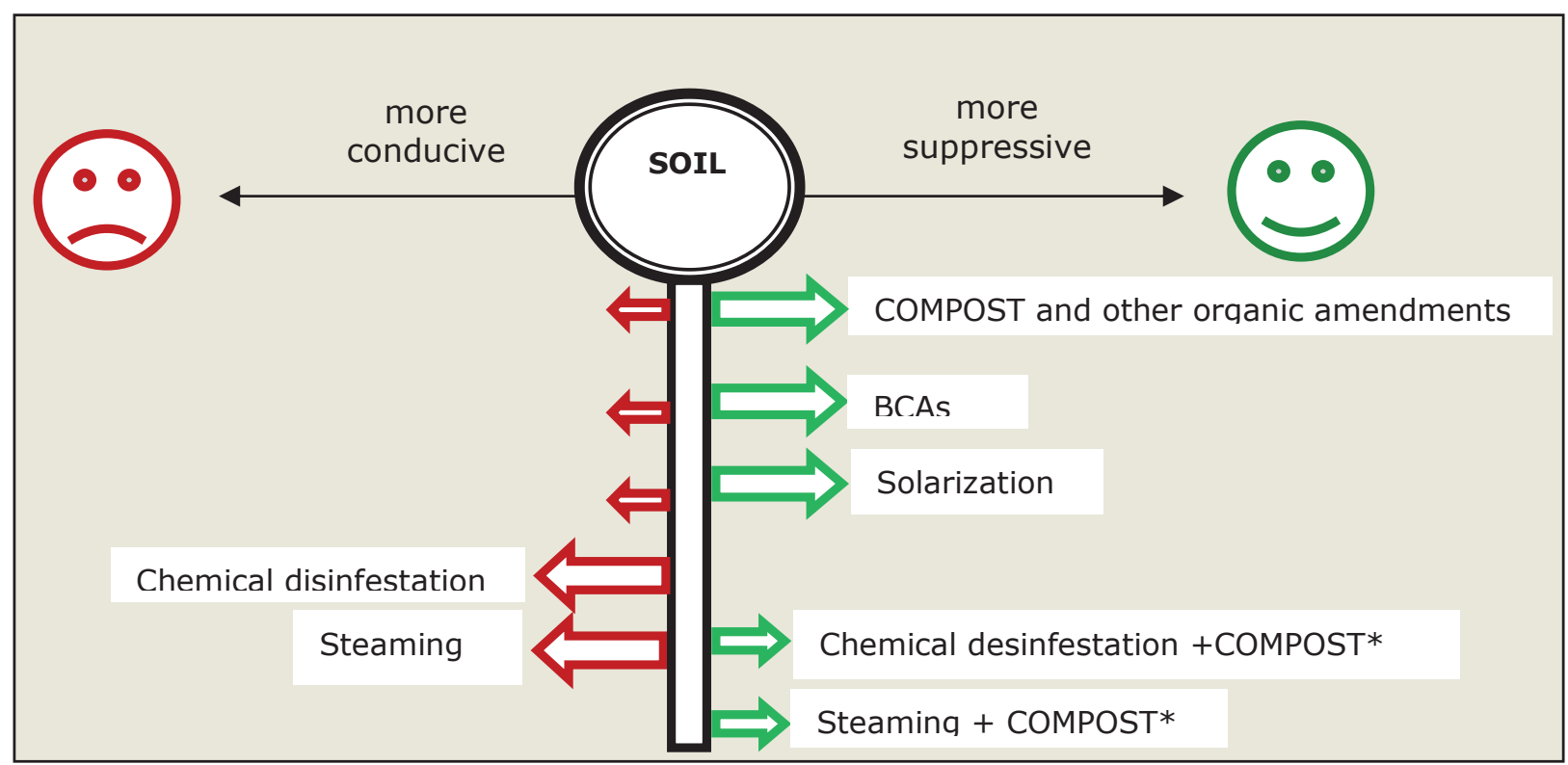

Figure 6.2 Some cultural practices that can influence disease suppressiveness in the greenhouse. Red arrows indicate practices that make the soil more conducive. Green arrows indicate practices that make soil more suppressive. The size of the arrow indicates the magnitude of the effect of the practice. *COMPOST: indicates that compost should be applied immediately after chemical disinfestation or steaming.

\subsection{Use of compost: A key farming practice to increase suppressiveness}

Soils and substrates are living systems. They need to be fed with organic materials. Compost is one of the most important organic amendments used in horticulture. Besides improving soil physical and nutritional conditions, compost can particularly help to increase disease suppressiveness.

There are different types of compost (see e.g. chapter 2). Each type of compost interacts differently with biotic and abiotic factors of the soil, resulting in different levels of suppressiveness. Although complex, the interactions between compost and soil rarely result in a decrease of disease suppressiveness. A recent (meta)analysis of many studies involving compost and suppressiveness to diseases has indicated that in more than $50 \%$ of the studies, compost increased suppressiveness to the disease tested. Stimulation of the disease by the application of compost only occurred in less than $12 \%$ of cases $^{6}$.

It is important to keep in mind that suppressiveness is often pathogen-specific and is related to the mechanism(s) of disease suppression. Different composts can also have large differences in the disease suppression they induce?

\subsection{Suppressiveness against specific pathogens}

The effect of compost has been intensively studied on the plant pathogens Rhizoctonia solani and several species of Fusarium, Verticillium, Pythium and Phytophthora. Most studies have been performed on vegetable and ornamental crops, such as tomato, cucumber, sweet pepper, pea, melon, lettuce, impatiens and poinsettia. When the studies were analysed together, it showed that the effects were different among the pathogens ${ }^{6}$ (Figure 3 ). The application of compost increased suppressiveness of wilt, crown rot, and root rot caused by Fusarium, in $74 \%$ of the studies, while in $23 \%$ it was ineffective and only in $3 \%$ was the disease aggravated compared to the non-compost amended control. Thus, compost is an important tool to increase suppressiveness against Fusarium.

Compost application was able to increase disease suppressiveness to Pythium (damping-off and crown-, and root rot), Phytophthora (crown and root rot) and Verticillium (wilt) in approximately $60 \%$ of the studies. The number of cases that the disease was stimulated (decrease of suppressiveness) was lower for Pythium and Phytophthora (less than $10 \%$ ) than for Verticillium (18\%). 
Damping-off caused by Rhizoctonia was the most difficult disease to be controlled by compost. In $48 \%$ of the cases, compost was ineffective and in $20 \%$, it increased conduciveness. Disease suppression was observed in only $32 \%$ of the studies.

Compost can reduce the severity of corky root in soil-based cultivation of tomato caused by Pyrenochaeta lycopersici $^{8}$. In cauliflower, the use of compost can decrease clubroot caused by Plasmodiophora brassicae ${ }^{9}$. The combination of compost application with other strategies, such as liming and use of resistant cultivars can offer a sustainable management of clubroot ${ }^{9}$.

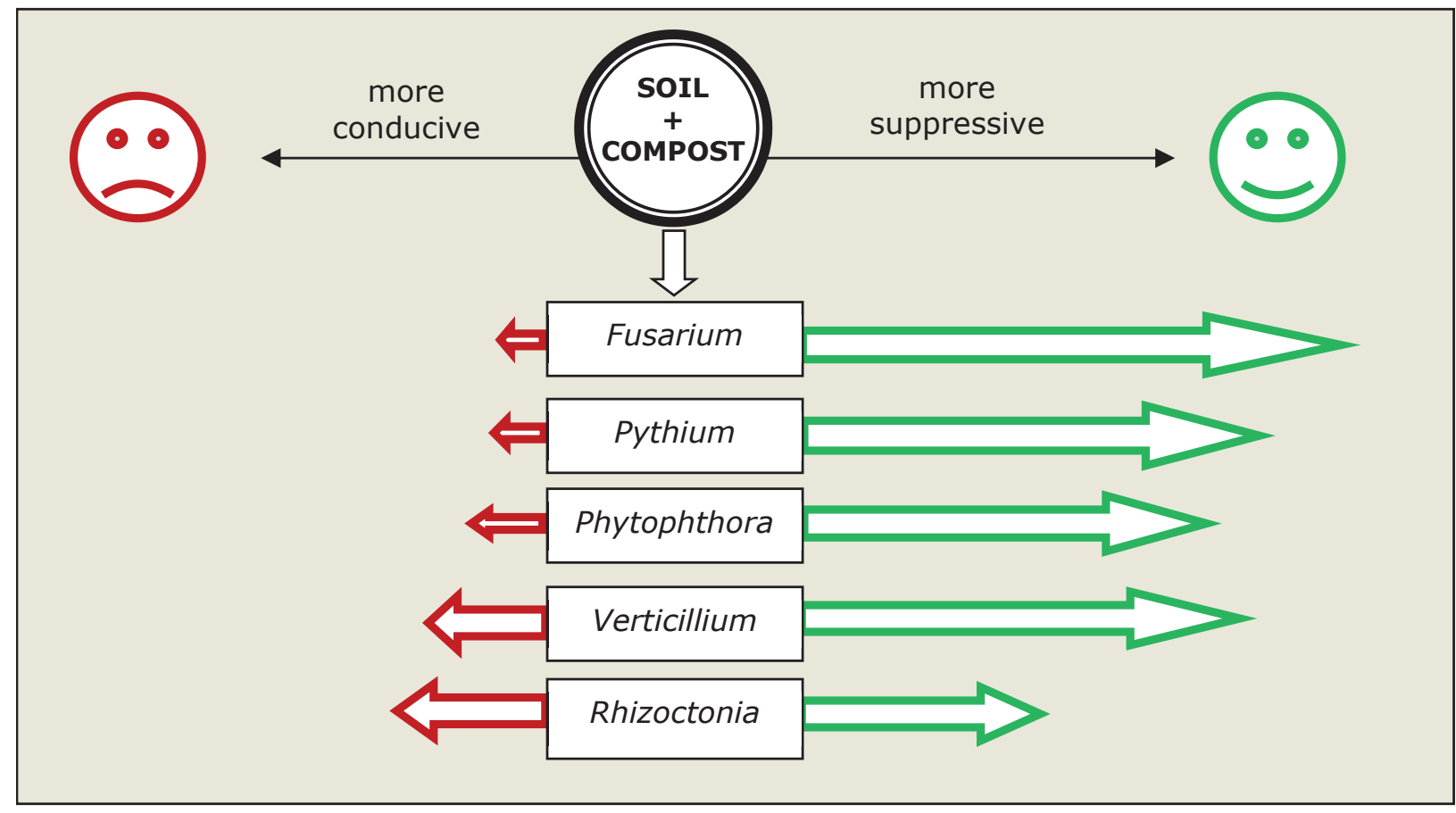

Figure 6.3 Effect of compost on disease suppressiveness on the most studied soil-borne diseases (based on a large literature survey by Bonanomi et al. 2007). Red arrows indicate increased disease after compost addition and green arrow, increased disease suppression. The size of the arrow indicates the frequency of the effect in the total of studies analysed.

Compost also influences the dynamics of plant-parasitic nematodes. Yield losses caused by the root-knot nematodes Meloidogyne javanica and $M$. hapla have been reduced using compost ${ }^{10}$.

Although the effect of compost on bacterial diseases has been less studied, compost seems to contribute to disease control. Bacterial canker and wilt of tomato, caused by Clavibacter michiganensis subsp. michiganensis and Ralstonia solanacearum, respectively, are examples of diseases that have been reduced by compost application $^{11,12}$.

Interestingly, the positive effect of compost is not limited to soil-borne diseases, but it extends to foliar diseases. In compost-amended growing media, reduction of gray mold (Botrytis cinerea) on cucumber and melon has been reported ${ }^{13}$. The same has been observed with the bacterial leaf spot (Xanthomonas campestris pv. vesicatoria) on tomato ${ }^{14}$. 


\title{
6.4 Mechanisms of disease suppression
}

\author{
6.4.1 Proposed effect of compost
}

The effect of compost on disease suppressiveness is predominantly biological, i.e., it usually involves the activity of microorganisms in soil/substrate and plant roots. So, if compost is sterilised, it loses most of its suppressive capacity ${ }^{15}$. Compost not only introduces beneficial microorganisms into the system, but also stimulates the microbial community already present in soil or substrate.

Compost can also affect disease suppressiveness by changing the physical and chemical properties of soil and influencing the nutritional status of plants. For example, moderate electrical conductivity values and high concentrations of ammonium in compost seem to be involved in the suppression of plant-parasitic nematodes ${ }^{16}$ and $R$. solani ${ }^{17}$. However, application of ammonium into the soil may favour other diseases, such as Fusarium wilt ${ }^{18}$, indicating that compost application should be pathogen-tailored. This is usually not problematic as a grower is mostly confronted with only a limited number of major soil-borne pathogens.

In many cases, compost decreases disease by negatively affecting the pathogen population in the soil or substrate. However, compost can also decrease disease without reducing the amount of pathogen. Concerning root lesion and other plant-parasitic nematodes, compost often do not reduce or they even stimulate their populations, but nevertheless they do increases crop yields. One possible explanation for this phenomenon is that free-living nematodes are also stimulated by composts. High populations of free-living nematodes are, in general, beneficial because they are involved in several processes in soil, such as nutrient mineralization ${ }^{10}$.

\subsubsection{Effect on pathogen/ nematode}

- Kill pathogen/ nematode Natural enemies may cause a decline in the pest or disease. Examples are the bacterium Pasteuria penetrans and the nematode-trapping fungus Arthrobotrys spp. and Dactylella ${ }^{19}$. Other microorganisms commonly present in soil or compost are fungi belonging to the genus Tricohoderma. Trichoderma may produce antibiotics and some are important mycoparasites.

- Avoid pathogen germination or growth

Competition for food in the rhizosphere of host plants likely plays an important role, such as competition for biologically available Fe (iron) between plant-parasitic Pythium foot rot and fluorescent pseudomonads. Faster growing fungi, such as Trichoderma, may play an important role in the competition for resources. Another well-known mechanism of disease suppression is the competition for carbon produced in the rhizosphere between plant-parasitic Fusarium species and non-parasitic Fusarium species². Non-pathogenic Fusarium oxysporum strains can have fungistatic effect on pathogenic $F$. oxysporum strains, inhibiting the germination of their spores in the soil amended with compost ${ }^{20}$.

\subsubsection{Effect on plants}

Growth promotion and induced resistance are other mechanisms that can be involved in the suppression of pests and diseases. Several Trichoderma species have the ability to promote growth and protect the roots of plants. Many other fungi and bacteria that live in the rhizosphere or inside the plants can also protect plants by these mechanisms. 


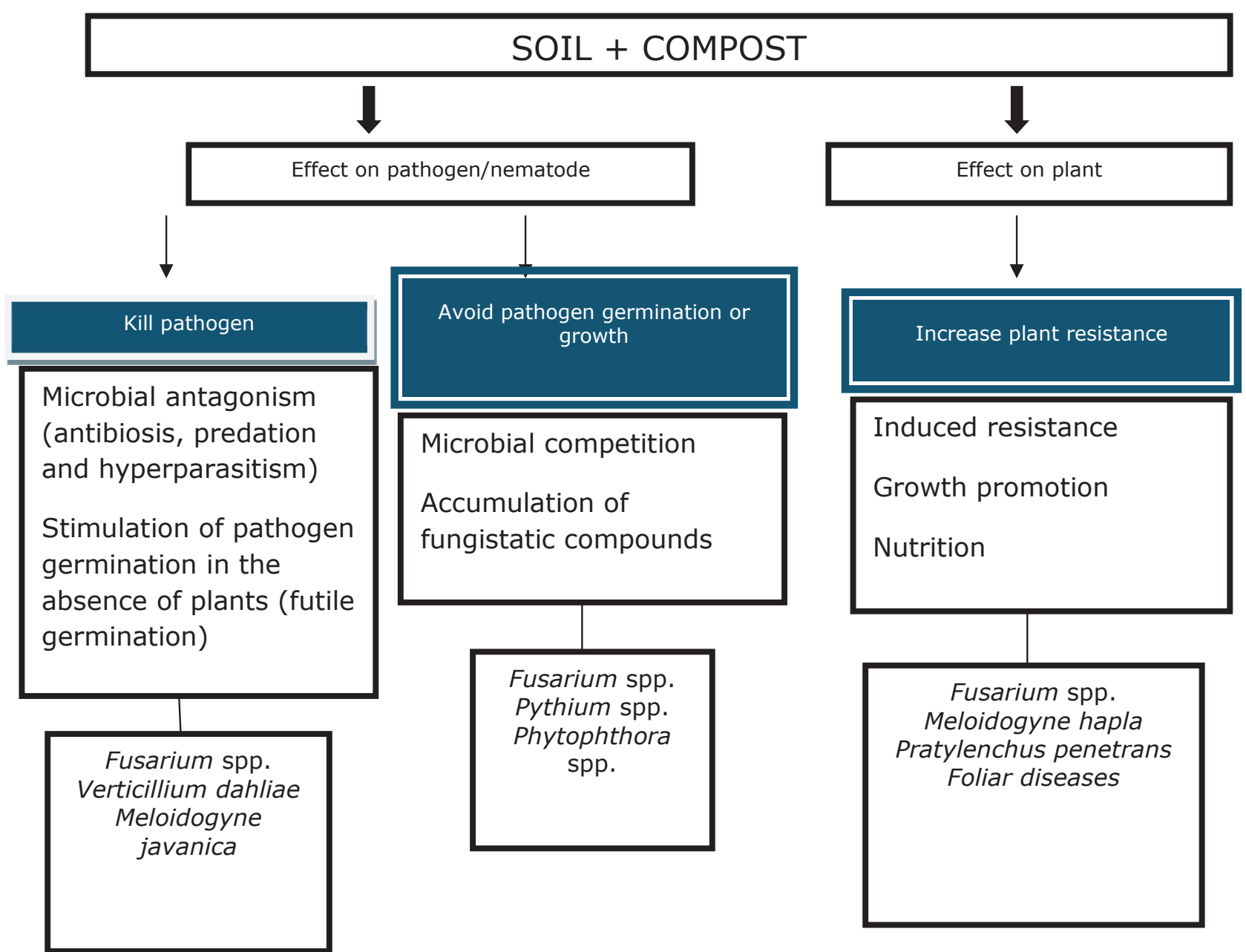

Figure 6.4 Mechanisms of disease suppressiveness involved in compost application and examples of pathogens controlled by these mechanisms.

\subsection{Important considerations}

- Clear effects of compost application are expected in sandy soils and soils with low organic matter content. This can be attributed to changes in soil structure and microbiological activity owing to the increase of biological available organic matter, and increase in plant nutrients.

- The effect of compost is temporal. It lasts only for a certain period after the application.

- Amount and frequency of application is important. In soil, continuous additions of low to moderate amounts are recommended (10-20 $\mathrm{t} \mathrm{ha}^{-1}$ per year). In plant-growing media, a single application of a high amount of compost that is low in EC is advised (20-30\% (v:v).

- Microorganisms that colonize the compost in the maturation phase are very important for suppressive capacity of the compost ${ }^{21}$. Some biological agents commercially available were originally isolated from compost that showed capacity of increasing disease suppression.

- Inclusion of lignin-rich feedstock in the compost enhances its suppressive capacity. This type of material is not easily degradable and provides useful compounds to feed beneficial microorganisms in the maturation phase ${ }^{22}$.

- Young compost is more effective in suppressing Pythium ${ }^{20}$, while mature compost is recommended against Rhizoctonia ${ }^{23}$.

- Prolonged compost maturation may or may not reduce the compost capacity to suppress diseases 24,25

- The suppressive capacity of compost can be steered by adding selected specific antagonists during the maturation phase ${ }^{15,21}$. Efficient strains of Trichoderma can be added to the compost at the maturation phase. The compost then becomes more effective in the control of specific pathogens, such as Rhizoctonia.

- Contamination with pathogens should be avoided in the maturation phase (see chapter 5. on hygienization). 


\subsection{References}

1. Baker KF, Cook RJ (1974).

Biological Control of Plant Pathogens. San Francisco: Freeman, 433 pp.

2. Alabouvette C (1999).

Fusarium wilt suppressive soils: an example of disease-suppressive soils. Australian Plant Pathology 28: 57-64.

3. Larkin RP, Hopkins DL, Martin FN (1996).

Suppression of Fusarium wilt of watermelon by non pathogenic Fusarium oxysporum and other microorganisms recovered from a disease-suppressive soil. Phytopathology 86: 812-819.

4. Wurff, A.W.G. van der; Slooten, M.A. van; Hamelink, R. ; Bohne, S. ; Wensveen, W. van (2011). Soil suppressiveness towards Meloidogyne Verticillium or Pythium in greenhouse horticulture. In: 1 International Conference on Organic Greenhouse Horticulture. Acta Horticulturae 915, p. 141 - 149.

5. Schönfeld J, Gelsomino A, Overbeek LS, van Gorissen A, Smalla K, van Elsas JD (2003).

Effects of compost addition and simultaneous solarisation on the fate of Ralstonia solanacearum biovar 2 and indigenous bacteria in soil. FEMS Microbial Ecology 43: 63-74.

6. Bonanomi G, Antignani V, Pane C, Scala F (2007).

Suppression of soilborne fungal diseases with organic amendments. Journal of Plant Pathology 89: 311324.

7. Termorshuizen, A.J., E. van Rijn, D.J. van der Gaag, Y. Chen, J. Lagerlöf, E.J. Paplomatas, B. Rämert, C. Steinberg, S. Zmora (2006)

Disease suppression of 18 composts against 7 pathogens. Soil Biology and Biochemistry 38: 2461-2477.

8. Giotis C, Markelou E, Theodoropoulou A, Toufexi E, Hodson R, Shotton P, Shiel R, Cooper J, Leifert C (2009). Effect of soil amendments and biological control agents (BCAs) on soil-borne root diseases caused by Pyrenochaeta lycopersici and Verticillium albo-atrum in organic greenhouse tomato production systems. European Journal of Plant Pathology 123: 387-400.

9. Myers, D.F., R.N. Campbell (1985).Lime and the control of clubroot of Crucifers: Effect of pH, calcium, magnesium and their interactions. The American Phytopathological Society 75: 670-673.

10. Thoden TC, Korthals GW, Termorshuizen AJ (2011).

Organic amendments and their influence in plant-parasitic and free-living nematodes; a promising method for nematode management? Nematology 13: 133-153.

11. Yogev A, Raviv M, Kritzman G, Hadar Y, Cohen R, Kirshner B, Katan J (2009). Suppression of bacterial canker of tomato by compost. Crop Protection 28: 97-103.

12. Schönfeld J, Gelsomino A, Overbeek LS, van Gorissen A, Smalla K, van Elsas JD (2003). Effects of compost addition and simultaneous solarisation on the fate of Ralstonia solanacearum biovar 2 and indigenous bacteria in soil. FEMS Microbial Ecology 43: 63-74.

13. Yogev A, Raviv M, Hadar Y, Cohen R, Wolf S, Gil L, Katan J (2010). Induced resistance of compost suppressiveness. Biological Control 54: 46-51.

14. Aldahmani JH, Abbasi PA, Sahin F, Hoitink HAJ, Miller SA (2005).

Reduction of bacterial leaf spot severity on radish, lettuce and tomato plants grown in compost-amended potting mixes. Canadian Journal of Plant Pathology 27: 186-93. 
15. Noble R (2011).

Risks and benefits of soil amendment with composts in relation to plant pathogens. Australasian Plant Pathology 40: 157-167.

16. Oka Y (2010).

Mechanisms of nematode suppression by organic soil amendments-a review. Applied Soil Ecology 44: 101-115.

17. Pane, C. Chiantese, C. Scala, F. Bonanomi, G. (2013).

Assessment of gardening growing media suppressiveness against Rhizoctonia damping-off disease. Journal of plant pathology 95(2): 401-405.

18. Huber DM, Thompson IA (2007).

Nitrogen en Plant Disease. In: Mineral Nutrition and Plant Diseases. Datnoff LE, Elmer WH, Huber DM (eds). APS, St. Paul, Minnesota U.S.A.

19. Van der Wurff, AWG, J. Janse, C.J. Kok, F.C. Zoon (2010).

Biological control of root knot nematodes in organic vegetable and flower greenhouse cultivation. State of Science - Report of a study over the period 2005 - 2010. Wageningen UR report 321, Wageningen UR Greenhouse Horticulture, Bleiswijk, The Netherlands.

20. Larkin RP, Hopkins DL, Martin FN (1996). Suppression of Fusarium wilt of watermelon by non pathogenic Fusarium oxysporum and other microorganisms recovered from a disease-suppressive soil. Phytopathology 86: 812-819.

21. Hoitink HAJ, Stone AG, Han DY (1997).

Suppression of plant diseases by composts. HortScience 32: 184-187.

22. Hoitink, H.A.J. (2004).

Disease suppression with compost: history, principles and future. In: I International Conference Soil and Compost Eco-biology Sept. 15th-17th 2004, León, Spain.

23. Borrero, C. Castillo, S. Casanova, E. Segarra, G. Trillas, M. I. Castano, R. Aviles, M. (2013). Capacity of composts made from agriculture industry residues to suppress different plant diseases. Acta Horticulturae 1013: 459-463.

24. Zmora-Nahum S., Danon M., Hadar T., Chen Y. (2008).

Compost curing reduces suppression of plant diseases. Compost Sci. Util. 16: 250-256.

25. Saadi, I., Laor, Y., Medina, Sh., Krasnovsky, A. and Raviv, M. (2010).

Compost suppressiveness against Fusarium oxysporum was not reduced after one-year storage under various moisture and temperature conditions. Soil Biology and Biochemistry 42: 626- 634. 


\title{
7 Compost vs. Digestate
}

\author{
Jacques G. Fuchs
}

\section{In short}

- Basically, there are two ways to decompose organic matter: composting (aerobic = with oxygen) and anaerobic digestion (= without oxygen).

- From the nutrient point of view, the major difference between compost (product resulting from composting process) and digestate (product resulting from anaerobic digestion) is the fate of nitrogen. In compost, the majority of the nitrogen is organically bound and only small quantity of mineralized nitrogen is available for plants. In digestate, a significant amount of the nitrogen is present in mineral forms (mostly ammonium) and is available for the plants.

- The organic matter of compost is more stable than the organic matter of digestate. Therefore, compost contributes more to soil structure, organic matter content and humic acids in the soil and, generally, contributes more to disease suppression.

- Digestates are still phytotoxic and cannot be used in high quantities so they are not appropriate as component for growing media or for planting holes.

- During composting, the organic material undergoes a natural hygienization. Plant and human pathogen are inactivated by thermophilic anaerobic digestion (process temperature $50-60^{\circ} \mathrm{C}$ ). A mesophilic process $\left(30-40^{\circ} \mathrm{C}\right)$, however, cannot guarantee a product free from human and plant pathogens without additional treatment like composting.

- Digestate has a stronger but shorter-term fertilization effect than compost, but compost has a better middle- and long-term effect on humus content and soil structure than digestate. So the choice of the product used depends on the desired effect.

\subsection{Introduction}

Composting represents an important and well established part of residue management in Europe. In recent years, anaerobic treatment of organic residues leading to production of non-fossil energy have been promoted and thus, production of liquid or solid digestate (i.e. the products from liquid/solid separation of the fermenters output) has increased. A digestate is solid if its dry matter content is above $20 \%$, and liquid if it is lower. Basically, anaerobic digestion is mainly a degradation process of the more labile fraction of the organic waste (1), whereas composting leads to stable forms of humus during the curing phase. Hence, the humic acid contents are very low in digestate and very young composts, and increase with the curing phase of composting $(2,3,4,5)$. It is possible to produce stabilized compost from digestate with appropriate post-treatment.

Both compost and digestate can be used for plant production and can influence soil fertility and plant health. However, as the characteristics of these products differ, their application differs (Figure 7.1). 


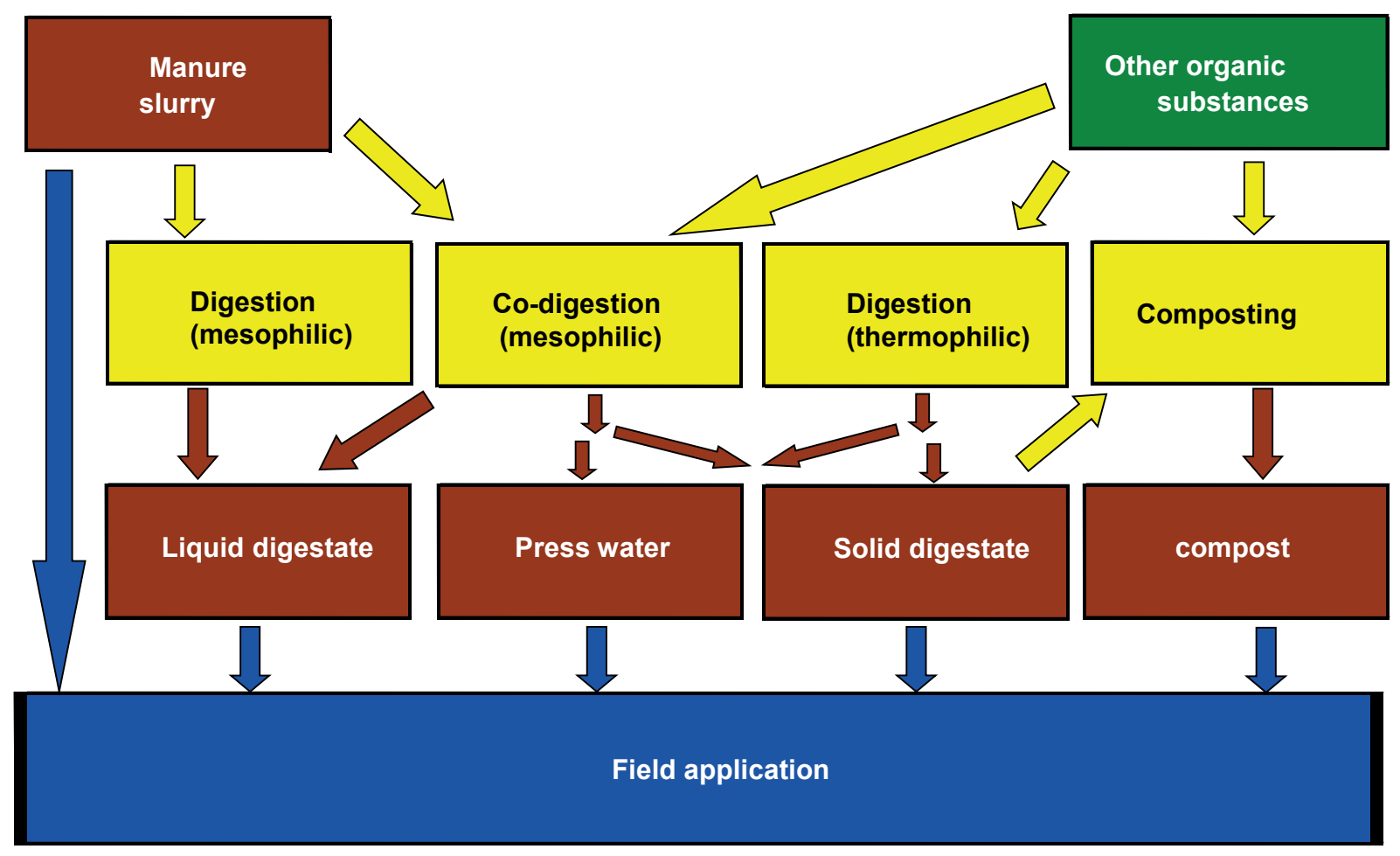

Figure 7.1 Pathways for processing manure slurry and other organic substances via digestion or composting.

\subsection{Anaerobic digestion processes}

The most commonly used anaerobic digestion processes operate at either mesophilic $\left(30-40{ }^{\circ} \mathrm{C}\right)$ or thermophilic (50-60 ${ }^{\circ} \mathrm{C}$ ) temperatures. Thermophilic digestion can have a higher metabolic rate, and has a larger degree of pathogen deactivation. However, depending on the input materials, thermophilic digestion may not be feasible, as accumulation of ammonia and volatile fatty acids (VFAs) may disrupt the process (6). At the same time, mesophilic digestion processes may be able to sustain higher organic loading rates, and can therefore be more attractive.

Co-digestion (i.e. the simultaneous digestion of various feedstocks at the same time) is often applied for agricultural wastes, since digestion of liquid manure alone has a low methane yield. Input materials like food wastes contain relatively high proportions of highly biodegradable organic matter. On the other hand, when the organic loading rate of these feedstocks becomes high, digestion of these input materials may fail due to the accumulation of inhibitory intermediates, such as ammonia and VFAs.

In anaerobic digestion, four microbial processes are involved: hydrolysis, fermentation, acetogenesis and methanogenesis. Different microbial communities are responsible for these processes, and it is important that the populations are in balance at each trophic level. It has been suggested that thermophilic conditions may enhance the imbalance between fermentative and methanogenic microbes, which is reflected as an accumulation of volatile fatty acids. As a result, the digestion process may fail (7).

As digestates spend limited time in the digester (the energy efficiency declines with time), the resulting digestate is not completely exhausted in terms of easily degradable organic compounds. The stability of the end product can vary greatly depending on the input materials. The increase in stability of the end product is the result of the degradation of the labile organic constituents, which leaves the remaining organic matter more stable. However, no humification takes place during digestion. Experiments showed that the use of silage (containing solid lignocellulosic materials) and cattle manure as co-substrates result in lower dissolved organic carbon (DOC) contents and a higher stability of the end product. Digestates based on cattle slurry co-digested with orange peels also showed a relatively high stability. In contrast the use of glycerine as a co-substrate resulted in very unstable digestate, with high DOC values (up to $28 \mathrm{~g} \mathrm{~L}^{-1}$ ), and a high C/N ratio, which may result in $\mathrm{N}$ immobilization when applied to agricultural fields (8). 

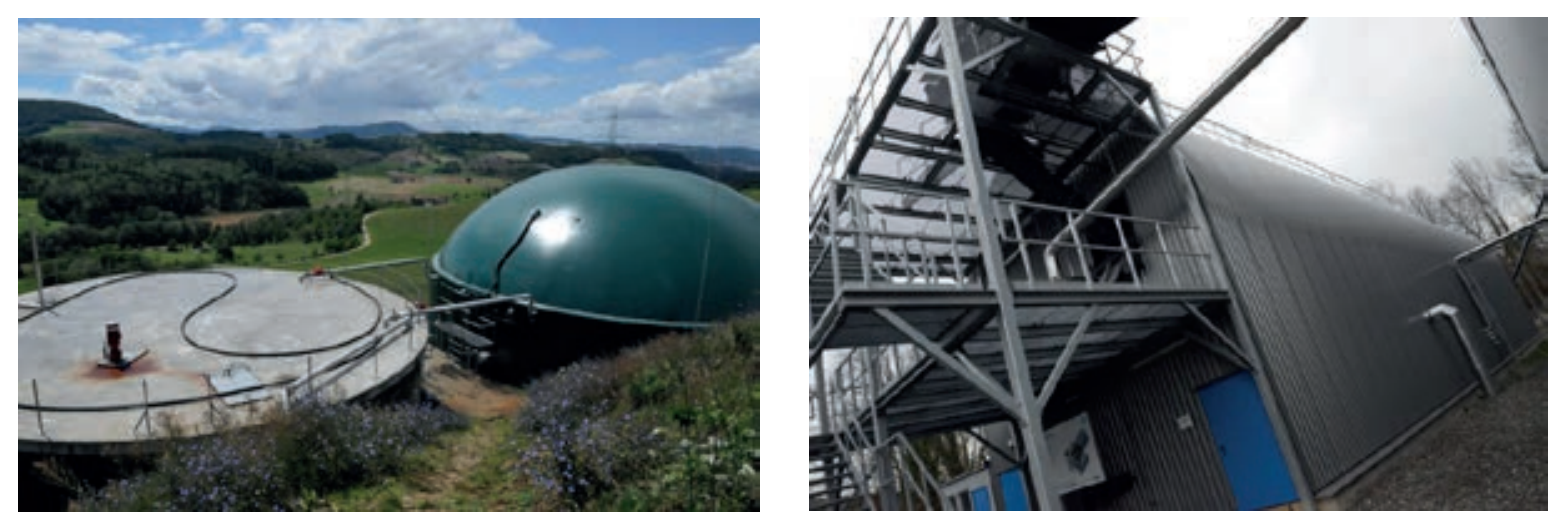

Figure 7.2 View of a mesophilic anaerobic co-digester (left) and an industrial thermophilic anaerobic digester (right).

\subsection{Characteristics of compost and digestate}

\subsubsection{Total nutrient contents}

Different composts and digestates vary greatly in the total nutrient contents per dry matter of the final products. It is however primarily the input mixture and not the system itself that influences the nutrient content of the final product. Starting with the same input, the total nutrient contents in compost and in digestate are largely similar. However, inadequate process management can greatly affect the nitrogen content due to ammonia losses. When the digestate is separated into two fractions, the concentrations (per unit of DM) of N, P and K are higher in the liquid part and the concentration of $\mathrm{Ca}$ (calcium) is higher in the solid part.

Dry matter content plays a very important role in the nutrient contents per volume, especially in the case of liquid digestate.

\subsubsection{Mineral nitrogen}

The nitrogen in composts and digestates is mostly present in the form of organic $\mathrm{N}$, which is less readily available to plants. A relatively small part of it is present as mineral nitrogen: ammonium $\left(\mathrm{NH}_{4}-\mathrm{N}\right)$, nitrite $\left(\mathrm{NO}_{2}-\mathrm{N}\right)$ and nitrate $\left(\mathrm{NO}_{3}-\mathrm{N}\right)$. The mineralized nitrogen forms $\mathrm{NH}_{4}-\mathrm{N}$ and $\mathrm{NO}_{3}-\mathrm{N}$ are directly available to the plants, while $\mathrm{NO}_{2}-\mathrm{N}$ is phytotoxic. Correct process management should ensure that $\mathrm{NO}_{2}-\mathrm{N}$ does not accumulate in compost but is transformed into $\mathrm{NO}_{3}-\mathrm{N}$, although some $\mathrm{NO}_{2}-\mathrm{N}$ can be measured in composts at the beginning of the nitrification process. This is due to the fact that microorganisms which transform $\mathrm{NH}_{4}-\mathrm{N}_{\text {into }} \mathrm{NO}_{2}-\mathrm{N}$ are faster than those which transform $\mathrm{NO}_{2}-\mathrm{N}$ into $\mathrm{NO}_{3}-\mathrm{N}$. This $\mathrm{NO}_{2}-\mathrm{N}$ is then quickly transformed into $\mathrm{NO}_{3}-\mathrm{N}$ in the soil after compost application. If mature compost is stored without sufficient oxygen supply, the $\mathrm{NO}_{3}-\mathrm{N}$ can be transformed back to $\mathrm{NO}_{2}-\mathrm{N}$. Such compost can produce severe phytotoxicity symptoms on plants.

The composition of the different forms of nitrogen represents the main difference between composts and digestates.

Composts generally contain significantly much less mineral- $\mathrm{N}$ than digestates. Compost cannot therefore be considered as an $\mathrm{N}$ fertilizer. Young C-rich composts can even immobilize soil- $\mathrm{N}$ for a certain time and thus negatively influence plant growth.

Digestates contain a relatively higher quantity of mineral- $\mathrm{N}$ and thus have a stronger fertilizer effect. Special care has to be taken for the storage and application of digestates, because most of the mineralized $\mathrm{N}$ is in the form of ammonium $\left(\mathrm{NH}_{4}^{+}\right)$, which can be volatilized as ammonia $\left(\mathrm{NH}_{3}\right)$ in the presence of air (e.g. if the digestate is drying). 
Table 7.1

Nitrogen forms in composts and digestates.

\begin{tabular}{llll} 
& Compost & Solid digestate & Liquid digestate \\
$\begin{array}{l}\text { \% of total nitrogen in } \\
\text { the form of mineralized } \\
\text { nitrogen }\end{array}$ & $0-20$ & $20-40$ & $40-70$ \\
\hline $\begin{array}{l}\text { Main form of mineralized } \\
\text { nitrogen }\end{array}$ & $\begin{array}{l}\text { young compost: } \mathrm{NH}_{4}^{+} \\
\text {mature compost: } \mathrm{NO}_{3}^{-}\end{array}$ & $\mathrm{NH}_{4}^{+}$ & $\mathrm{NH}_{4}^{+}$ \\
\hline
\end{tabular}

\subsubsection{Organic matter}

The quantity of organic matter in composts and digestates is approximately the same, but the stability of the organic matters differs greatly. The organic matter of mature compost is relatively stable, and about $50 \%$ of the carbon present in this compost remains for a long time in the soil as humus, thus helping carbon sequestration. The organic matter of digestate is much less stable and only about $25-30 \%$ of its carbon contributes to humus formation.
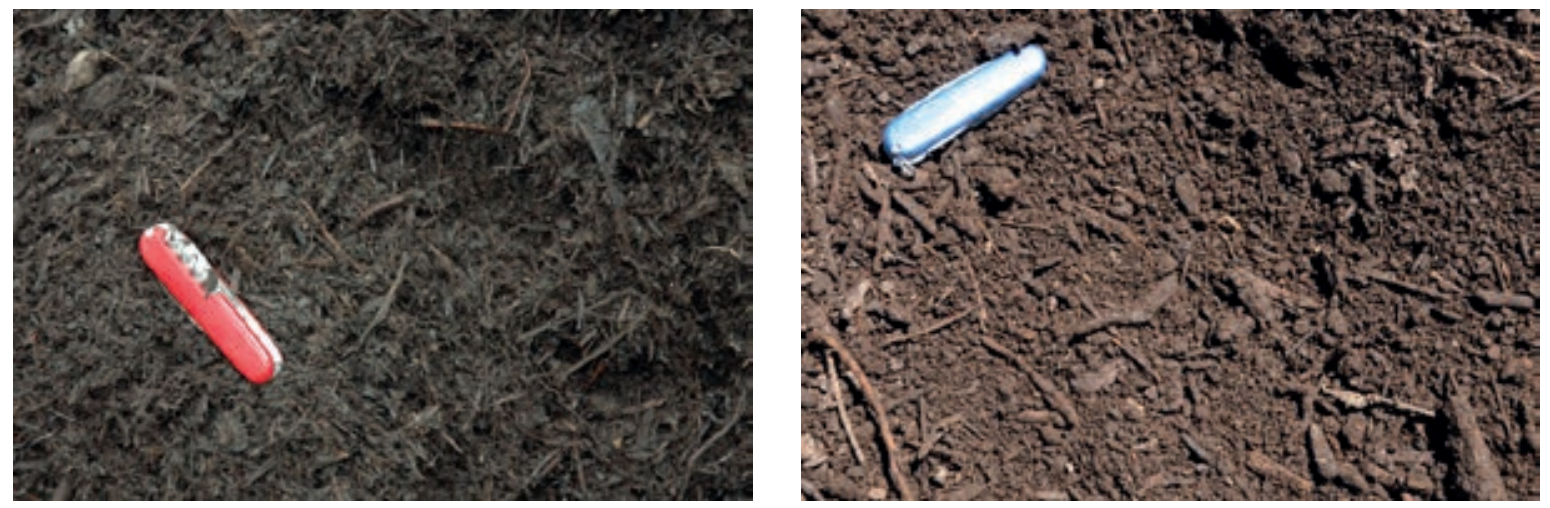

Figure 7.3 Solid digestate (left) contain still large amount of non-decomposed fibers, whereas in compost no organic material can be recognized, except for wood pieces (right).

\subsubsection{Salinity}

In a comparison of twelve different types of digestates, the highest EC values were found in pig slurry digestates and cattle slurry co-digested with cattle manure and maize-oat silage. Co-digestion of cattle slurry with glycerine or orange peels resulted in much lower EC values. High salinity may result in phytotoxicity for plants, and care should be taken especially when digestates are applied as readily available nitrogen sources in early plant stages. It is important that evaluation of the salinity considers which molecules are responsible for it; in practice, $\mathrm{NaCl}$ is most frequently responsible for high salinity. 


\subsection{5 $\quad \mathrm{pH}$}

The $\mathrm{pH}$ of most digestates is slightly alkaline. During the digestion process, the $\mathrm{pH}$ trend is to increase, due to volatile fatty acid degradation and ammonia production. The $\mathrm{pH}$ of digestate of animal slurries is generally alkaline, around 8 . The alkaline $\mathrm{pH}$ also causes that the predominant forms of nitrogen $\left(\mathrm{NH}_{4}\right.$ and $\left.\mathrm{NH}_{3}\right)$ can easily be lost by ammonia volatilisation during storage and application to the ground (8). Depending on the stage of anaerobic digestion, the $\mathrm{pH}$ may vary between 6.8 and 8.5. Lower $\mathrm{pH}$ values would inhibit methane production as methane bacteria cannot survive at these levels. Many food waste feedstocks decompose very quickly, which can result in a too strong acidification of the digester contents, and inhibition of the digestion process. Appropriate post-digestion of the digestate should transform the $\mathrm{NH}_{4}-\mathrm{N}$ to $\mathrm{NO}_{3}-\mathrm{N}$ (nitrification) and so reduce the $\mathrm{pH}$.

\subsubsection{Plant compatibility}

Composts produced in accordance with good processing practice are highly compatible with most plants and are not phytotoxic, even when used at relatively high application rates. Digestates are not stabilized products and contain significant quantities of intermediate molecules which are phytotoxic (Figure 7.4). To avoid phytotoxicity symptoms, only a moderate quantity of digestate can be used per application. Digestate is not appropriate for the production of growing media (see below).
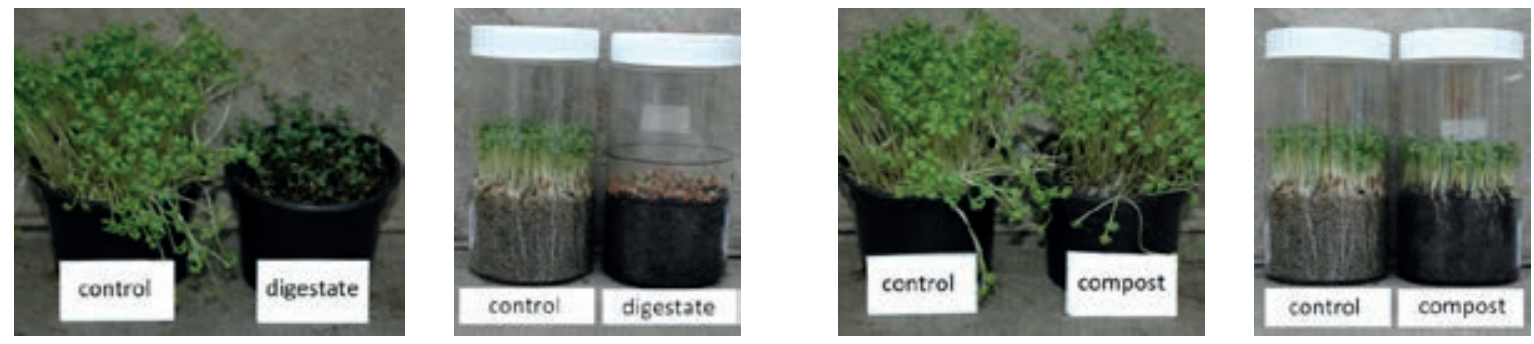

Figure 7.4 Phytotoxicity of digestate (left) and mature compost (right).

\subsubsection{Hygiene}

During the composting process, the organic materials undergo a natural hygienization. Thus, compost can be considered safe with respect to weeds and pathogens (see chapter 5).

Anaerobic digestion is efficient in the destruction of weed seeds. If the anaerobic digestion is performed using a thermophilic process $\left(50-60^{\circ} \mathrm{C}\right)$, plant and human pathogens will be inactivated. However, when performed by a mesophilic process $\left(30-40^{\circ} \mathrm{C}\right)$, hygiene in relation to plants and human pathogens cannot be guaranteed without additional treatment.

\section{Table 7.2}

Comparison of the characteristics of composts and digestates.

\begin{tabular}{ll} 
Characteristic & Comparison of the products \\
Total nutrient content (per dry matter unit) & compost $\approx$ digestate \\
\hline Nutrients availability to plants (e.g. nitrogen) & digestate liquid $>>>$ digestate solid $>>$ compost \\
\hline Organic matter content per dry matter unit & compost $\approx$ digestate solid $\approx$ digestate liquid \\
\hline Stability of the organic substance & compost $>>$ digestate solid $>>>$ digestate liquid \\
\hline Phytotoxicity & digestate liquid $\approx$ digestate solid $>>>$ compost \\
\hline
\end{tabular}




\subsubsection{Organic contaminations}

As digestates and composts may be produced from the same input materials, they may suffer from the same contaminations with organic compounds. Swiss research found relatively low levels of PCBs (polychlorinated biphenyls) in compost and digestate samples, but relatively high amounts of PAHs (polycyclic aromatic hydrocarbons). The same research also analysed the amounts of pesticides that could be traced back in compost and digestates. Among these were 30 fungicides, mainly triazoles, but also 14 herbicides, 8 insecticides and 1 acaricide. For organic farmers, it is important to consider not only the organic origin of the liquid manure that is used, but also the origin of the different feedstocks that are used for co-digestion, to avoid contamination of soil with slowly degrading pesticides. Large amounts of fungicides were particularly related to the use of kitchen waste and could be traced back to the use of post-harvest fungicides on tropical fruits $(9,10)$. Feedstocks like citrus peels from conventional sources may thus imply a risk for organic farmers. On the other hand, very small amounts of highly persistent herbicides like aminopyralid may cause problems in tomato growing.

\subsection{Utilization of compost and digestate}

From the agronomic point of view, compost and digestate are complementary products. The choice of the product and the application strategy depends on the desired target effect.

\subsubsection{General remarks}

Both composts and digestates have to be incorporated in the upper $5-10 \mathrm{~cm}$ of the soil after their application. Digestates, especially liquid ones, have to be incorporated in the soil as soon as possible after spraying to avoid ammonia losses. When spraying digestates, it is important to take all possible measures to limit ammonia emission: in summer, spray the digestate if possible when the weather conditions are not too hot. For liquid digestate, dribble hose, ground level nozzles on sprayer or similar techniques may be used. It is also important to match the sprayed quantity to the plant's needs.

The calculation of the quantity of compost or digestate to be used should consider each fertilizing nutrient added. None of them should be given to the soil in a quantity that exceeds what the nutrient balance allows.

In greenhouse use, it is also important to be attentive to the salt quantity of the products, in order to avoid long term salinity problems in the soil.

Table 7.3

Recommendation for the utilization of composts and digestates in greenhouses.

\begin{tabular}{llll} 
& Compost & Solid digestate & Liquide digestate \\
Short- and middle-term fertilization effect (nitrogen) & -- & ++ & +++ \\
\hline Improvement of soil structure & +++ & + & - \\
\hline Disease protection & +++ & ++ & + \\
\hline Component for plant media & +++ & -- & --
\end{tabular}

\subsubsection{Target fertilization}

Digestates are appropriate for short to medium-term fertilization. Digestates (especially liquid digestates) have a high availability of nutrients (mainly nitrogen) for the plant. Composts cannot be considered as nitrogen fertilizers. Young C-rich composts can even immobilize nitrogen for a period of time. 


\subsubsection{Target improvement of soil structure}

The humus molecules of compost stay relatively stable in the soil and thus they can improve soil structure on in the medium to long-term. This effect will also positively influence the water holding capacity and the aeration of the soil, and hence diminish the risks of erosion. The effect of solid digestate on the soil is less important than that of compost. Liquid digestate does not improve soil structure; moreover it can adversely affect soil structure if applied in too high quantities. This because excesses of $\mathrm{K}$ and $\mathrm{NH}_{4}$ in the soil can exchange with the hydrogen on the soil particles, and then the $\mathrm{pH}$ decreases and the soil structure disintegrates.

\subsubsection{Target plant growing media (substitute of peat)}

Mature compost is a good component in plant growing media if its salt content is acceptable (choice of input materials). An advantage of high quality compost is its biological activity, which allows the protection of plants against diseases. High pH values of composts can limit their usable quantity especially for some ornamental plants. It is possible to slightly lower the $\mathrm{pH}$ of the plant media using sulphur, but compost has a strong buffering capacity, and the effect of sulphur is limited if the compost percentage in the media is high. Because of their phytotoxicity, digestates are not appropriate as components of plant media.

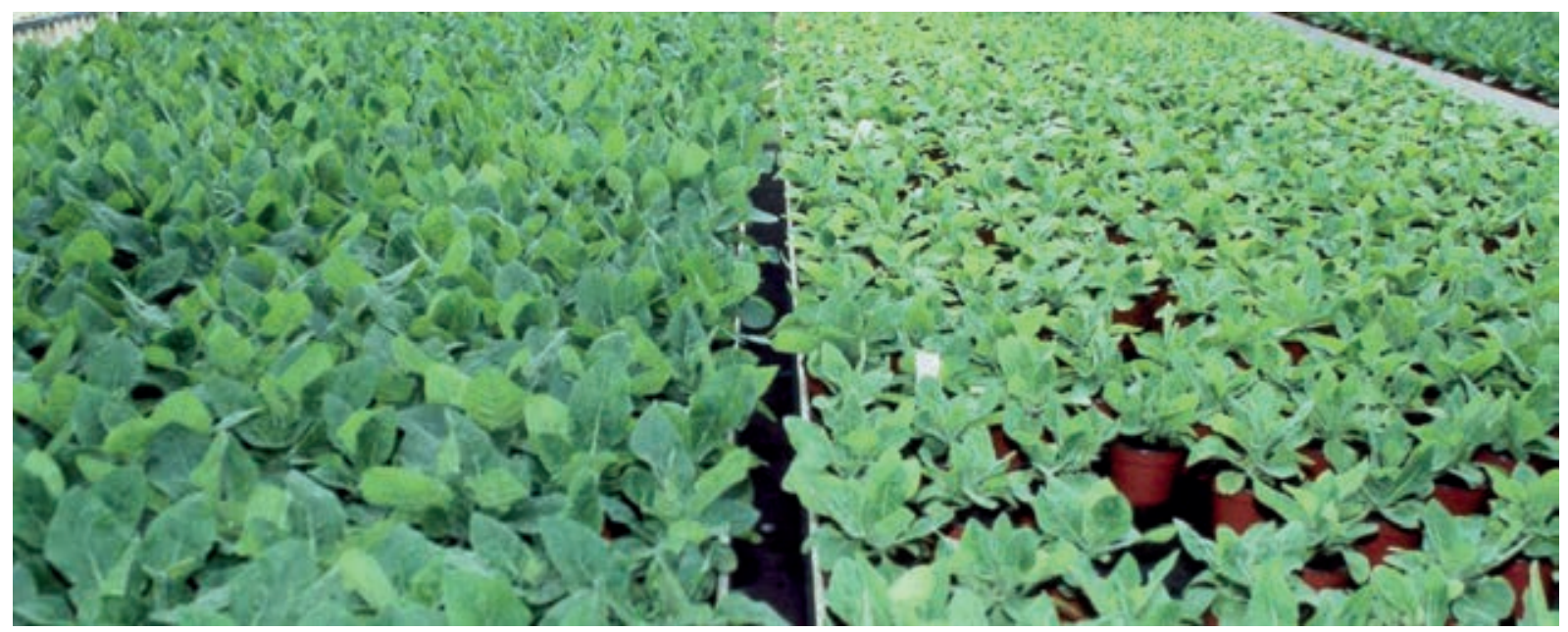

Figure 7.5 With the choice of the appropriate product, the plants grow well (left). With an inappropriate product (e.g. young lignin-rich compost), nitrogen can be immobilized, blocking plant growth (right).

\subsection{Application techniques}

\subsubsection{Digestate use in greenhouses}

Experiments with filtered liquid digestates are currently being carried out to test the applicability for specific purposes such as fertigation in organic greenhouses. Due to the high salt levels, digestates have to be diluted considerably before applying as drip fertilizers. This is not only decreasing the nutrient contents but also reduces the level of plant nutrition that can be reached. To prevent clogging of drip lines, it is necessary to alternate fertilization with digestate with regular flushing of the drip lines with water.

\subsubsection{Compost use in greenhouses}

If the soil is treated by steaming or solarization, the application of the compost immediately after these operations can give good results by helping to regenerate soil's microbial life. 
For plants such as tomatoes or cucumber, it is also possible to apply the compost directly in the planting holes. In this case, at least $50 \%(\mathrm{v} / \mathrm{v})$ of soil should be mixed with the compost.

\subsubsection{Compost use in plant media}

Compost can be mixed with other plant media components using regular methods for media production. Storage of plant media with compost should include some oxygen supply. It is recommended that organic nitrogen fertilizers are added just before using the plant media; otherwise, uncontrolled mineralization of nitrogen could occur during storage.

\subsection{Conclusions}

Liquid digestate, solid digestate and compost are products which are relevant for use in Organic greenhouses. They have different characteristics, and it is important to choose the appropriate product for each specific application and the desired effects. These organic fertilizers can be combined during the growing season. So it is important to think about a global strategy that includes liquid digestate, solid digestate and compost.

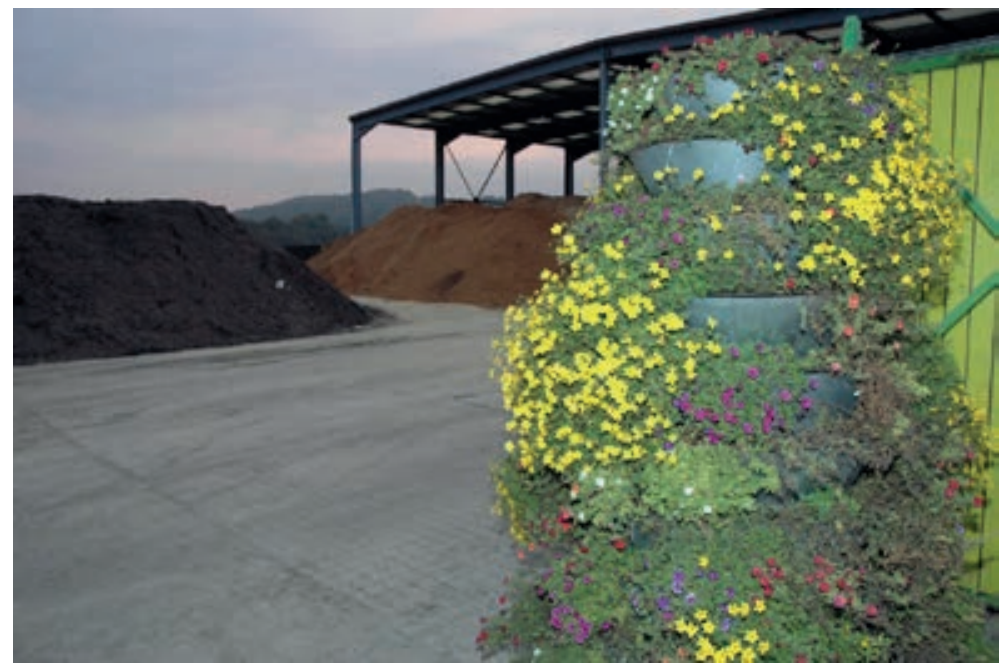

Figure 7.6 A good strategy of utilization of compost and digestate offer interesting perspectives for the plant grower.

\subsection{References}

1. Tambone F, Genevini P, D'Imporzano G, Adani F. (2009).

Assessing amendment properties of digestate by studying the organic matter composition and the degree of biological stability during the anaerobic digestion of the organic fraction of MSW. Bioresource Technology 100: 3140-3142.

2. Fuchs JG, Berner A, Mayer J, Smidt E, Schleiss K. (2008).

Influence of compost and digestates on plant growth and health: potentials and limits. Pages 101-110 in J.G. Fuchs TK, L. Tamm, K. Schenk, ed. CODIS 2008: Compost and digestate: sustainability, benefits, impacts for the environment and for plant production. Solothurn, Switzerland: FiBL, Research Institute of Organic Agriculture, Frick, Switzerland.

3. Lhadi EK, Tazi H, Aylaj M, Genevini PL, Adani F. (2006).

Organic matter evolution during co-composting of the organic fraction of municipal waste and poultry manure. Bioresource Technology 97: 2117-2123. 
4. Sanchez M, Gomez X, Barriocanal G, Cuetos MJ, Moran A. (2008).

Assessment of the stability of livestock farm wastes treated by anaerobic digestion. International Biodeterioration \& Biodegradation 62: 421-426.

5. Smidt E, Binner E, Lechner P, Meissi K, Tintner J, Ebner T. (2008).

Huminstoffe als Qualitätsparameter für Komposte und zur verfahrenstechnischen Optimierung von Kompostanlagen. A-1190 Wien: Universität für Bodenkultur Wien, Department für Wasser - Atmosphäre - Umwelt, Institut für Abfallwirtschaft.

6. Bayr, S., M. Rantanen, P. Kaparaju and J. Rintala. (2012).

Mesophilic and thermophilic anaerobic co-digestion of rendering plant and slaughterhouse wastes. Bioresource Technology (104) 28-36.

7. Guo, X, C. Wang, F. Sun, W. Zhu and W. Wu. 2014.

A comparison of microbial characteristics between the thermophilic and mesophilic anaerobic digesters exposed to elevated food waste loadings. Bioresource Technology (152) 420-428.

8. Alburquerque, J.A., C. de la Fuente, A. Ferrer-Costa, L. Carrasco, J. Cegarra, M. Abad and M. Pilar Bernal. (2012).

Assessment of the fertiliser potential of digestates from farm and agroindustrial residues. Biomass and Bioenergy (40) 181-189.

9. Brändli, R.C., T.D. Bucheli, T. Kupper, R. Furrer, W.A. Stahel, F.X. Stadelmann and J. Tarradellas. (2007a). Organic pollutants in compost and digestate. Part 1. Polychlorinated biphenyls, polycyclic aromatic hydrocarbons and molecular markers. Journal of Environmental Monitoring (9) 456-464.

10. Brändli, R.C., T. Kupper, T.D. Bucheli, M. Zennegg, S. Huber, D. Ortelli, J. Müller, C. Schaffner, S. Iozza, P. Schmid, U. Berger, P. Eddler, M. Oehme, F.X. Stadelmann and J. Tarradellas. (2007b).

Organic pollutants in compost and digestate. Part 2. Polychlorinated dibenzo-p-dioxins, and -furans, dioxin-like polychlorinated biphenyls, brominated flame retardants, perfluorinated alkyl substances, pesticides, and other compounds. Journal of Environmental Monitoring (9) 465-472. 
88 I Handbook for Composting and Compost Use in Organic Horticulture 


\section{Compost for soil application and compost for growing media}

\section{Chris Blok}

\section{In short}

- Soil properties of importance are dry bulk density, organic matter content, nutrient content and water holding capacity.

- Rooting media properties of importance are $\mathrm{pH}$, EC, water retention, water uptake rate, porosity, stability, shrinkage and nitrogen fixation.

- Miscommunication between producers and user groups can be avoided by measuring the relevant properties using methods users are familiar with.

- Special attention is needed to interpret total nutrients, extracted nutrients and organic matter content.

\subsection{Introduction}

Composts are used as soil improvers and as constituents of potting soils to grow plants. Soils and potting soils require composts with different properties. The required properties differ partly because of differences between mineral soil and growing media and partly because of differences between the way water and nutrients are added during the growing period. In some countries the term compost includes mixes with peat products. Confusion may arise where others refer to compost in a stricter sense. Compost in the stricter sense is defined as organic material which has been stabilised by an aerobic exothermic microbial conversion. Composts added to soils are generally finer graded materials with lower stability and higher salt contents than composts added to potting soils. As most composts tend to be more suitable for addition to soil than for use in potting soils, prices for the grades suitable for potting soils are higher.

The use of composts in growing media is restricted by certification bodies in some countries. The certification restrictions aim to not only avoid cultivation risks carried by composts such as salinity, high pH and instability but also limit the possible content of weed seeds, plant diseases and human pathogens. The restrictions often describe a maximum quantity of compost allowed in mixes such as the $20 \%-\mathrm{v} / \mathrm{v}$ in the Netherlands used as a maximum by RHP (www.rhp. nl) certification. The certification requirements also include detailed instructions to avoid cross contamination during mixing, as well as tests to determine compost quality. There is however a tendency to make organic materials more suitable for use in rooting media by improved and more advanced processing ${ }^{1}$. It is therefore hoped future regulations granting access to markets will focus more and more on the intrinsic properties of the material rather than base restrictions on the general term compost. In experiments quantities up to $40 \%-\mathrm{v} / \mathrm{v}$ compost produced equally well for Begonia and chrysanthemum while strawberry and melon were grown on mixes with over $80 \%-v / v$ of compost ${ }^{2}$. 


\subsection{Influence of soil and growing media properties}

\subsubsection{Soil}

Soils may be characterised in numerical terms as predominantly mineral particles ranging from $2 \mu \mathrm{m}$ to 1000 $\mu \mathrm{m}$. The material is dense $\left(900-1500 \mathrm{~kg} / \mathrm{m}^{3}\right)$ and the pore volume is limited $(\max 20-40 \%-\mathrm{v} / \mathrm{v})$.

These quantified mineral soil properties have consequences for other properties:

1. The water permeability, especially in soils with small particles, is low (40 mm/h down to $1 \mathrm{~mm} / \mathrm{h}$ ).

2. The water holding capacity is also low, with values well below $40 \%-v / v$.

3. Soils with less than $1 \%-w / w$ organic matter tend to compact and consequently become water logged.

4. Soils low in organic matter content easily loose top soil material by wind erosion and water erosion.

5. Soils low in organic matter are prone to soil-borne diseases either through a lack of disease resilience incorporated in organic matter or because diseases are favoured by the more extreme temperature / flooding circumstances caused by low organic matter contents. Arbitrarily organic matter levels of $<2 \%-w / w$ are to be regarded as low although there is no fixed level for problems and dry bulk density and mineral composition interact with the critical organic matter content.

\subsubsection{Growing media}

Growing media or substrates may be characterised as predominantly organic material with particles ranging from 50 to $5000 \mu \mathrm{m}$. The material is light $\left(100-400 \mathrm{~kg} / \mathrm{m}^{3}\right)$ and the pore volume is high $(60-90 \%-\mathrm{v} / \mathrm{v})$. In large parts of the world, notably more arid areas, potting soils may be based on the use of porous inert materials like tuff, perlite, vermiculite, and plastic waste.

These quantified growing media properties have consequences for other properties:

1. The water permeability is high, with values higher than $1 \mathrm{~cm} / \mathrm{min}$ (which is roughly 10-times higher than that of mineral soil).

2. The water holding capacity is high, with values of $50-85 \%-v / v$.

3. The organic particles, in contrast to some (but not all) mineral particles, have internal porosity. This affects properties like water and air storage but also offers micro shelter for microbial life. Levels of life expressed as number of colony forming units (cfu) are typically $10^{8} \mathrm{cfu} / \mathrm{cm}^{3}$, a factor 100 times higher than in mineral soils ${ }^{3}$. When proper numbers of specific species of microorganisms are present, diseases caused by other microorganisms are supressed by several mechanisms of microbial interaction (see chapter 6).

\subsubsection{Conclusion}

It is understandable that compost properties such as density, total pore space, organic matter content, water permeability, water holding capacity, compaction and air content are more relevant to mineral soils than potting soils. The levels of these properties are already considerably higher in potting soils, to the extent that compost can add little in respect to those properties.

\subsection{Influence of water and nutrient supply systems}

\subsubsection{Soil}

In soil systems, water supply may be restricted to naturally occurring rain or supplemented by flooding, drip or overhead irrigation with irrigation intervals of several days to several weeks. In some more intensive cropping systems, micro-irrigation is used with intervals of hours or days. 
In the less intensively irrigated systems, nutrients are applied as a large base dressing of solid fertilising material and followed up with a few maintenance applications of solid fertilising materials or more frequent application of liquid fertilising materials mixed in the irrigation water (a.k.a. fertigation). In the more intensive micro-irrigation systems, the base dressing may still be applied as solid fertiliser material but more emphasis is on the frequent application of liquid fertiliser mixed in the irrigation water.

\subsubsection{Growing media}

In substrate systems, water supply is either by overhead irrigation or by micro-irrigation. Typical irrigation intervals are hours and days. In potting soil systems, a relatively small part of the crop nutrient needs is applied to the potting soil as base dressing and a relatively large part is applied as a series of maintenance applications, usually of liquid fertilising materials mixed in the irrigation water.

The shorter intervals for irrigation and nutrient application are a consequence of the often very small rooting volume assigned to a plant which may lead to much faster depletion than in soil systems.

\subsubsection{Conclusion}

It is understandable that the nutrient content of compost is more important for soil applications than for potting soil applications even though the difference is gradual rather than absolute.

Some typical uses with pictures are provided below (Figures 8.1-8.4). Note that material in use for propagation is usually fine textured $(<1 \mathrm{~mm})$ and with a high water holding capacity ( $>80 \%$; Figure $8.1 \mathrm{C}$; Figure $8.3 \mathrm{D}$ ).

Composts for propagation must be fine, have a high water holding capacity and at the same time excellent water uptake rates after drying, as well as a low EC content.

Potting plants (Figures 8.1B, 8.3A, 8.4A-C) require medium-sized particles $(1-10 \mathrm{~mm})$ and a fair rewetting rate ( $50 \%$ in 15 minutes). Composts in such mixtures should be stable and low in EC and should display a fair water uptake rate as well.

In nurseries for outdoor ornamentals (Figures 8.1D; 8.2A; 8.3C-D) compost used should be even more stable and still rewet on drying.

Composts used in strawberry (Figures $8.2 \mathrm{~B}-\mathrm{C}$ ) are wet at all times as drip irrigation is used so should have enough pore space for air transport, especially so because they are used in percentages of over $80 \%-\mathrm{v} / \mathrm{v}$.
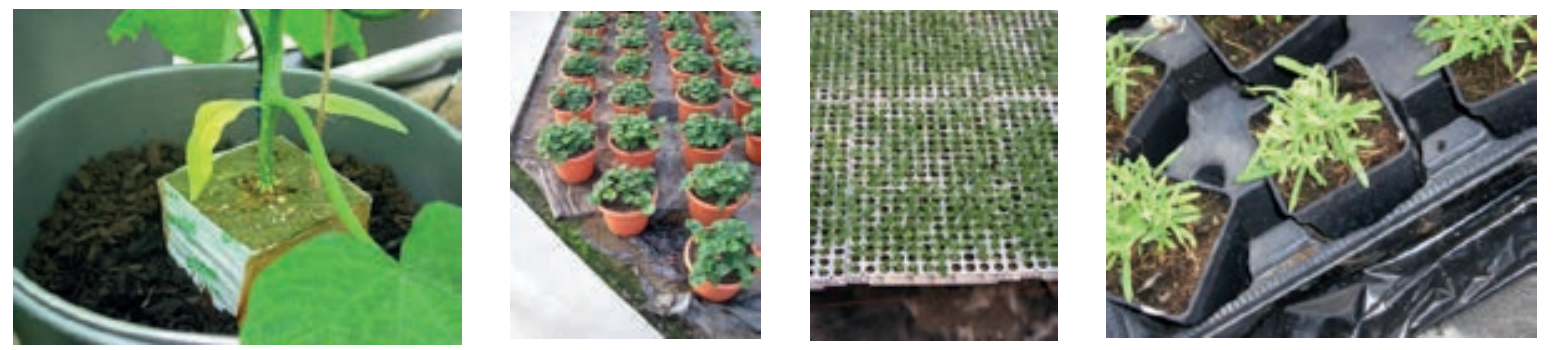

Figure 8.1 A) Under glass, drip irrigation, compost, cucumber, The Netherlands, 1999. B) Outdoor, overhead irrigation, geranium, France, 2005. C) Plastic house, overhead irrigation, propagation in cell trays France, 2005. D) Plastic house, overhead irrigation, ornamentals, France, 2005.
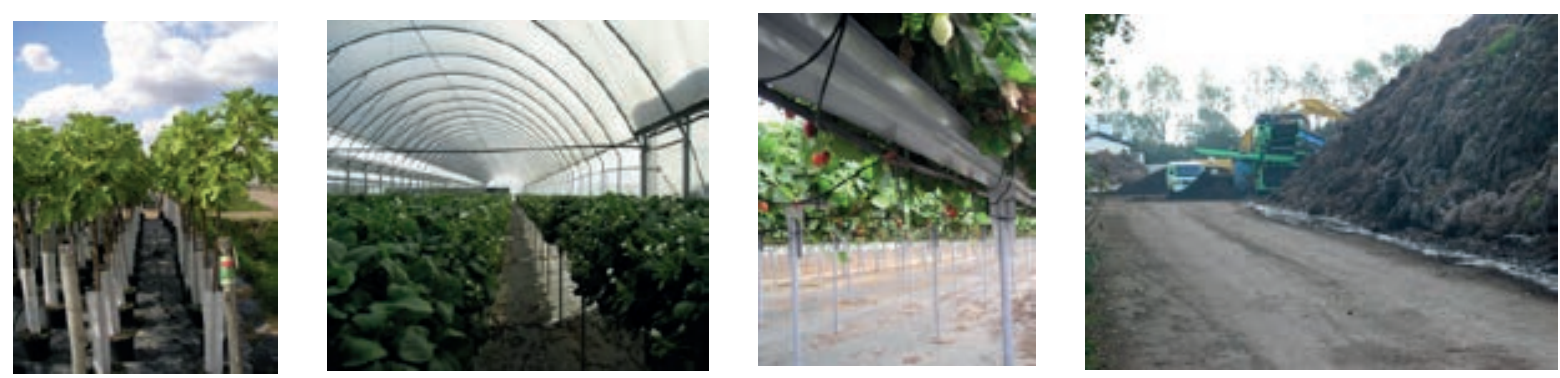

Figure 8.2 A) Outdoor, micro irrigation, tree crops, France, 2005. B) Plastic house, drip irrigation, compost, strawberry, Angers, 2005. C) Plastic house, drip irrigation, compost, strawberry, Angers, 2005. D) Compost production, raw materials, 2006, Alphen, The Netherlands. 

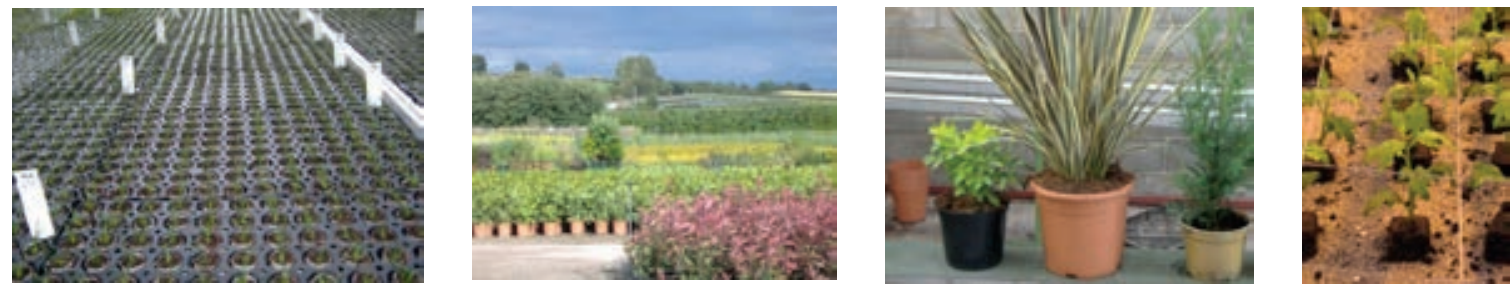

Figure 8.3 A) Under glass, overhead irrigation plus nutrients, Bromelia propagation, Bleiswijk, Holland 2007. B) Outdoors, cultivation of shrubs on peat free, Nottingham, England 2007. C) Outdoors, cultivation of shrubs on peat free, Nottingham, England 2007. D) Under glass, sub irrigation, peat press pot on sand, chrysanthemum, Holland, 2010.
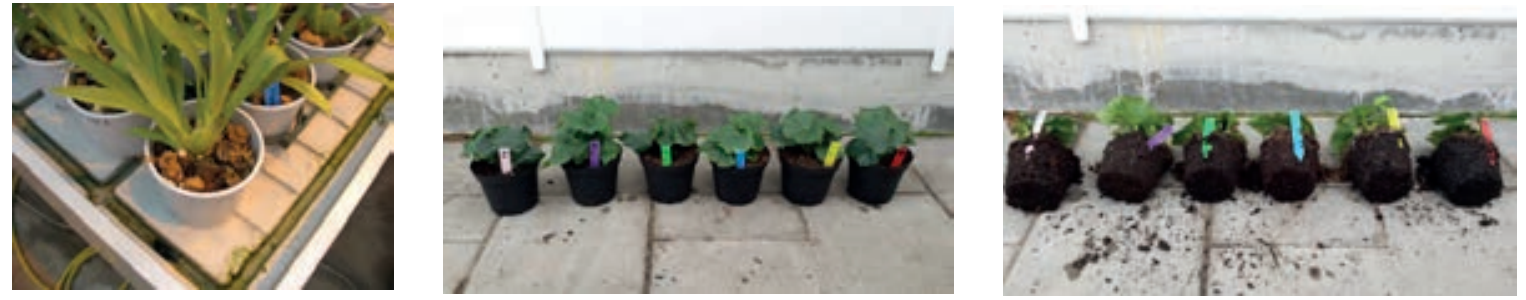

Figure 8.1 A) Under glass, sub irrigation, coir chips, Miltonia, The Netherlands, 2007. B) Under glass, sub irrigation, compost / peat, Begonia, The Netherlands, 2014. C) Under glass, sub irrigation, compost / peat, Begonia, The Netherlands, 2014.

\subsection{Compost functions in soil and growing media}

\subsubsection{Soil}

Compost for soil applications serves a number of functions:

1. Adding nutrients. The compost is valued as it recycles nutrients from prior applications to plants in need of those elements. The value of the compost is rated according to:

a. The amount of nutrients brought in, relative to the anticipated need of the plant and the soil. Plant need is calculated based on plant analysis and amount to be harvested. Soil need is calculated based on soil analysis and target levels for the specific soil.

b. The type of nutrient brought in. Nitrate is valued highly but is usually absent in compost material unless it is fully cured. Potassium and phosphorous are usually the most abundant elements and may limit the maximum amount of compost which can be applied.

c. The level of elements with a negative influence on plant and soil. Sodium and chloride are the most usual unwanted minerals. Their effects may include:

i. A direct toxicity effect above a threshold level.

ii. A disruption of the uptake of other elements notably calcium.

iii. Reduced fresh weight production caused by elevated EC.

2. Increasing organic matter content. A direct physical effect of mixing organic and mineral particles is an increase in the total pore space, resulting from formation of more complex soil aggregates. The increase in total pore space results in:

a. Lower bulk density;

b. Higher air content;

c. Higher water storage;

d. Higher infiltration rate.

3. Improving soil structure (decreasing soil density, increasing permeability for water, increasing air content, increasing water storage). Apart from the physical effect of mixing minerals with organic material, several other indirect effects take longer to kick in. The organic material can form complexes with clay minerals which increase the coherence of soil aggregates. 
4. Increasing the level of microbial activity, biological diversity and resistance against soil pathogens. The organic material offers micro shelters, carbon and nutrients for soil microbial life. Life levels easily reach levels $>100$ times those in pure mineral soils. The microbes will break down the organic material thus releasing mineral nutrients. The microbes also form fulvic and humic acids which mobilize trace elements such as iron, manganese, zinc and copper thus making these elements more plant available. The microbes form slimes and mucus which bind soil aggregates together into stable sub structures which improve soil structure. Finally the soil microbiological life and the organic matter itself attract meso- and macrofauna like springtails, nematodes and earthworms which may further improve soil structure. The microbiological life may hinder the development and action of plant pathogenic microorganisms through sheer abundance, competition for nutrients and specific interactions.

\subsubsection{Growing media}

Compost as a constituent for potting soils is evaluated differently compared to compost as a constituent for soil. Especially the functions "nutrient supply" and "organic matter content" are not valued as much as in soil growing, whereas microbial activity and water availability are possibly even more important than in soil:

1. Increasing level of microbial activity, biological diversity and resistance against soil pathogens. The organic material offers micro shelter, carbon and nutrients for soil microbial life. The microbiological life may hinder the development and action of plant pathogenic microorganisms through sheer abundance, competition for nutrients and specific interactions.

2. Increasing water availability. The mixing of organic and other rooting materials only results in a modest increase in the total pore space if the rooting materials are distinctly drier in nature such as bark or rice husks. More important is the possible increase in Easily Available Water (EAW). Materials which hold water with a force larger than $-50 \mathrm{~cm}$ water column are thought to hinder growth. Soils with $>20 \%-v / v$ EAW are favoured. Composts also improve the hydraulic conductivity of substrates.

3. Adding nutrients. Compost is valued by society as it recycles nutrients from previous applications to plants in need of those elements. For growers the nutrient contribution in e.g. container plants is relatively unimportant. The growth requirements of pot plants often exceed the maximum amount of nutrient in a container based on compost alone. It is therefore common to add a base dressing prior to growing in the substrate and to also add a maintenance supply of organic fertilizer by mixing organic fertilizers into the irrigation water. The value of the compost as fertilizer is rated according to:

4. The level of elements with a negative influence on plant and soil. $\mathrm{Na}$ (Sodium) and $\mathrm{Cl}$ (chloride) are the most common unwanted minerals. In many cases, the resulting high salinity (expressed as electrical conductivity of the extract) can limit plant growth.

5. The amount of nitrate immobilisation caused by the degradable part of the organic matter.

6. The fertilizer contribution. Nitrate is valued highly but usually absent in compost materials, unless fully cured. Potassium is usually the most abundant element and may limit the maximum amount of compost which can be applied.

7. Note the negative criteria are covered first, showing high risk awareness in this application.

8. Improving soil structure (decreasing soil density, increasing permeability for water, increasing air content, increasing water storage). This is generally of low importance as the properties of soil density, permeability, air content and water storage are not limiting growth in potting soils.

9. Increasing organic matter content. This is generally unimportant as the potting soil mixes already contain ample organic material.

10. Filler (replacing more expensive materials). This is an economically sound reason for using compost in potting soils though a distinct advantage in the issues 1-3 may be decisive. 


\subsubsection{Conclusion}

The important functions of compost for mineral soils and extensive management are adding nutrients / adding organic matter / improving soil structure and improving resilience, in that order. The important functions of compost for potting soils and intensive management are resilience / water availability / filler function in that order with much less interest in adding nutrients, organic matter or improving soil structure.

\subsection{Negative function indicators}

Composts may also decrease the performance of soil or potting soil mixes. Therefore a set of negative function indicators is mentioned. Many of these indicators only need to stay clear of critical values used in the market. Those that are less clear are discussed:

1. Nutrient content. At the moment most potting soil producers do not correct the nutrient spectrum of the base dressing in potting soils to complement the nutrients present in the added compost. The reason is that the fertilizers used by the potting soil producers have fixed NPK ratios and many adjustments for compost require single element additions. The use of single elements requires more expertise than some producers feel they can deliver, although it seems worthwhile to further this issue by supplying information. The reverse situation occurs where some elements in the compost are high enough to negatively affect plant growth or plant quality. The most common elements in excess are potassium and sodium. Often the amount of compost that can be mixed in soil or potting soil is limited by one or other of these elements.

2. Stability. Over time, the organic material may be broken down by microbial action. As a consequence the mix loses the positive influences of lower bulk density, higher air content, higher water storage, and higher infiltration rate. In potting soils the loss of volume and the increase in the downward movement of finer more mobile particles may result in worse properties than without compost. Therefore a certain basic stability of the compost is required.

3. Nitrogen immobilisation. The breakdown of organic matter by microbial action results in a massive uptake of nitrogen by microorganisms. As microorganisms compete for nitrogen more efficiently than plant roots, the nitrogen uptake by the plants can be severely restricted even when the total analysis shows ample nitrogen (immobilised in the microbial mass). An element analysis of the nutrient solution will demonstrate depletion though. Extra nitrogen may need to be added to maintain proper plant growth. To know the proper dose, the Nitrogen Fixation Index (NFI) is measured. More stable compost show less nitrogen immobilisation.

4. Hydrophobicity / rewetting rate. Some compost becomes increasingly hydrophobic upon drying. Especially in potting soils this is a negative property which can cause costly hand worked corrections of water content of plants in the borders of batches or fields i.e. those plants which evaporate slightly more.

5. Mineral matter content. A minimum may be required by certification bodies, usually $>20 \%-w / w$.

6. Heavy metal, PCA's, plant diseases, human diseases are all bound by legal upper limits. They are not discussed here in further detail.

7. Plant growth inhibitors and seeds. These obviously need to be absent altogether. Dedicated tests exist to ensure composts are indeed within the limits ${ }^{4}$.

\subsubsection{Conclusion}

The higher the yields per unit area of crop production get, the more important it is that negative properties are not introduced by the addition of compost, since these properties usually outweigh any positive properties. It is largely up to the producer to ensure his product is within limits but the existence of measurements is crucial for the customers. The measurements offer solid neutral and accepted ways to decide in case of conflicts over negative compost properties.

\subsection{Measuring quality}

To assess the quality of compost, basic properties must be measured to allow buyers and producers to effectively negotiate a price. Insufficient measurements will result in unfounded decisions, consequent poor results and a slowdown in the development of compost as a product. 
Condensing the above paragraphs, a table of properties is given (Table 8.1). For a description of the nature of the properties and a description of one or more methods to measure them, a reference is made to [5].

\section{Table 8.1}

Quality properties for various end users with units.

\begin{tabular}{|c|c|c|}
\hline Nr. & Parameter & Unit \\
\hline 1 & Analysis of nutriënt elements & $\mathrm{mmol} \cdot \mathrm{L}^{-1}$ \\
\hline 2 & Acidity, $\mathrm{pH}$ & $\mathrm{pH}$ \\
\hline 3 & Electro Conductivity, EC & $\mathrm{dS} \cdot \mathrm{m}^{1}$ \\
\hline 4 & Cation Exchange Capacity, CEC & $\mathrm{meq} / 100 \mathrm{~g} \mathrm{OM}$ \\
\hline 5 & Nitrogen Fixation Index, NFI & $\mathrm{mmol} / \mathrm{L}^{-1}$ \\
\hline 6 & Water Retention, PF1 & $\%-v / v$ \\
\hline 7 & Easily Available Water, EAW & $\%-v / v$ \\
\hline 8 & Water Uptake Rate, WUR & $\%-v / v$ \\
\hline 9 & Air content at saturation & $\%-v / v$ \\
\hline 10 & Total Pore Space, TPS & $\%-v / v$ \\
\hline 11 & Organic Matter (Content), OM & $\%-w / w D W$ \\
\hline 12 & Dry Bulk Density, DBD & $\mathrm{g} / \mathrm{cm}^{3} \mathrm{DW}$ \\
\hline 13 & Stability & $\mathrm{mmol} \mathrm{O}_{2} / \mathrm{kg} \mathrm{OM} / \mathrm{h}$ \\
\hline 14 & Shrinkage & $\%-v / v$ \\
\hline 15 & Organoleptic control & unspecified (see 9.2) \\
\hline
\end{tabular}

OM Organic Matter

DW Dry Weight

Composters sometimes report properties and methods used for the internal process control of a composting plant $^{1}$. This can result in readings that have little or no value for the end users. Examples are composting time and temperatures reached.

Composters also report end user relevant properties of importance using unfamiliar methods. This can results in the failure of end users to understand reported values. Examples are $\mathrm{EC}, \mathrm{pH}$ and nutrient content. The results are very different and virtually impossible to read if one is not familiar with the exaction method.

Some of the common sources of confusion are: available versus total nutrients; choice of extraction method; reporting units in $\mathrm{mg}$ or $\mathrm{mmol}$; Using $\%-\mathrm{v} / \mathrm{v}$ or $\%-\mathrm{w} / \mathrm{w}$. These will be discussed below.

\subsubsection{Available versus total element analysis}

Sixteen to twenty elements in the correct ratios need to be present in solution at the root surface. Therefore only the elements actually in the substrate solution are measured as available elements. Many materials, including compost, also contain nutrients which are not readily soluble. These nutrients may become available later during cultivation so a second type of analysis is needed to show the total elements, including the ones in store. 
During cultivation periodic analyses of plant available elements help growers to avoid fluctuations by adding maintenance supplies of nutrients. A total element analysis is usually made at the beginning of the cultivation period. When an excess of one or more elements is found, plant growth may be reduced. When a lack of an element is found, additional fertilisation is needed in order to avoid deficiency. When compost is mixed with other potting soil constituents, the amount of fertiliser in the compost must be subtracted from the amount needed by a particular crop. Potting soil producers often administer compensating amounts of nutrients to potting soil mixes prior to delivery taking into account crop, growing system, water quality and grower wishes. This is an important service for growers! If the compost contains more of an element than is needed in the soil or potting soil mix, the total application of compost must be reduced to avoid over fertilising and possible growth reduction.

\subsubsection{Choice of extraction}

When growers need to know the plant available amount of nutrients, i.e. the amount present in the solution around the roots, an extraction method is used. In an extraction method soluble elements that are washed out of the compost are said to be available. Extraction of nutrients from compost is less easy and therefore a surplus of liquid is used. Results differ depending on the amount of surplus solution used, as the concentrations measured are diluted. The choice of surplus liquid also influences the results. The amount of nutrients in the surplus after extraction depends on the $\mathrm{pH}$ of the extractant solution used, the amount and nature of cations used and the use of molecules added to release iron. Many methods exist and among the methods used are extract dilution methods such as the $1: 1.5,1: 2$, and $1: 5$ methods as well as extract solvent solutions such as CAT, pH-KCL and $\mathrm{CaCl}_{2}$ solutions. Table 8.2 shows the dilutions expected when using some of the extraction dilution methods. The EU is currently preparing the certification of soil improvers and rooting materials and proposes to use the $1: 5$ extract method ${ }^{6}$. The advantage is the straight forward procedure but the disadvantage is a gross over estimation of some poorly dissolvable salts like $\mathrm{CaSO}_{4}$ (gypsum) and lower accuracies reported by the routine laboratories involved.

Table 8.2

Influence of extraction methods on dilution.

\begin{tabular}{llllll} 
& $\begin{array}{l}\text { Soil } \\
\text { moisture }\end{array}$ & $\begin{array}{l}\text { Saturation } \\
\text { extract }\end{array}$ & $1: 1.5$ & $1: 2 \mathrm{~V}$ & $1: 5 \mathrm{w}$ \\
Dilution compared to SMC (plant experience) & 1 & 2.3 & 4.0 & 4.4 & 17.7 \\
\hline Dilution compared to pF1 & 0.6 & 1.4 & 2.4 & 2.7 & 10.6 \\
\hline Dilution compared to saturation & 0.5 & 1.2 & 2.0 & 2.2 & 8.8 \\
\hline Dilution compared to sample volume & 0.3 & 0.7 & 1.2 & 1.3 & 5.3 \\
\hline
\end{tabular}

Soil moisture: for systems in which extracts are squeezed or sucked out of the sample. Saturation extract: extracts squeezed or sucked out of the sample after saturation (like the Pour Thru method7; $1: 1.5$ : create standard wetness (pF1); add 50\%-v/v water to the sample volume; $1: 2$ : saturate the sample; take $100 \%-v / v$ water volume and add sample until the total volume is $150 \%-v / v ; 1: 5:$ a laboratory compacted sample is prepared; $500 \%-v / v$ water is added ( 5 times the sample volume). 


\subsubsection{Reporting $\mathrm{mg}$ or $\mathrm{mmol}$}

Growers who add solid materials to their soil and use compost as a fertiliser source need to know the amount of nutrients in weight per unit area. Thus they will want to know the amount of single elements in unit weight per unit dry matter \%-w/w, as well as the water content in \%-w/w of the fresh compost. Growers who add compost to their potting soils need to correct their nutrient solutions for the elements already applied in $\mathrm{mg} / \mathrm{L}$ and want to know how much of an element is already present in a unit volume of their medium, again in mg/L. In most countries element levels are reported in $\mathrm{mg}$ although some countries use mmol or meq. All scientific literature uses meq. Minor advantages are that quality checks on the results are much easier when using mmol or meq and the fact that this method of expression is linearly related to salinity. The amount of cations and anions can be checked for in a balance calculation and the EC can be assessed and checked against a measured EC.

\subsubsection{Using $\%-v / v$ or $\%-w / w$}

Certifying bodies demand a minimum content of organic material of $20-30 \%-w / w$. The quantity is reported in $\%-w / w$ rather than $\%-v / v$. As long as the organic material is mixed with mineral soil with densities of 1000-1250 $\mathrm{kg} / \mathrm{m}^{3}$ this is not confusing. Once composts are mixed with materials which are considerably lighter, possibly even lighter than the compost itself, \%-w/w becomes meaningless. Table 8.3 illustrates this for a mix with mineral soil and a mix with perlite as potting soil constituent.

\section{Table 8.3}

Soil organic matter content in sand-compost and perlite-compost mixes, expressed as $\%-v / v$ and $\%-w / w$.

\begin{tabular}{lllllll} 
DBD Sand & DBD compost & OM & Minerals & O.M. & DBD & OM \\
$\mathrm{kg} / \mathrm{m}^{3}$ & $\mathrm{~kg} / \mathrm{m}^{3}$ & $\%-\mathrm{v} / \mathrm{v}$ & $\mathrm{kg}$ & $\mathrm{kg}$ & $\mathrm{kg} / \mathrm{m}^{3}$ & $\%-\mathrm{w} / \mathrm{w}$ \\
\hline 1600 & 200 & 50 & 800 & 100 & 900 & $11.1 \%$ \\
\hline 100 & 200 & 50 & 50 & 100 & 150 & $66.7 \%$ \\
\hline DBD & Dry Bulk Density & & & & & \\
OM & Organic Matter & & & & &
\end{tabular}

To reach a level of $50 \%-v / v$ organic matter in sand $11.1 \%-w / w$ is needed. To reach $50 \%-v / v$ organic matter in perlite $66.7 \%-w / w$ is needed (Table 8.3 ). Of course the amount a grower needs to buy is exactly equal. The reason for the apparent difference is entirely caused by the difference in density of the receiving materials. An even more important reason to prefer $\%-v / v$ is that roots and soil microbes both experience the amount of organic matter in their environment on a volume basis (how far until the next organic particle). Disease resilience is predicted by the amount of organic matter in $\%-v / v$ much more clearly than in $\%-w / w$.

\subsubsection{Conclusion}

For soil / extensive systems the required analyses are focussed on total analysis, $\mathrm{mg} / \mathrm{kg}$ and organic matter in $\mathrm{w} / \mathrm{w}$. For potting soils / intensive systems more and more emphasis will be on extract analysis in the $1: 1.5$ extract in $\mathrm{mmol} / \mathrm{l}$ or $\mathrm{mg} / \mathrm{kg}$, and organic matter in \%-v/v. Developments in the EU seem to require the 1:5 extract method but may allow recalculating the $1: 5$ to the $1: 1.5$ method. 


\subsection{General conclusion}

1. It is important for producers to report data using methods the user is familiar with. Table 8.1 provides a list of information of relevance for growers.

2. For nutrient elements two analyses are advised: a total analysis in element quantities in $\mathrm{mg} / \mathrm{kg}$ and a $1: 1.5$ analysis in $\mathrm{mg} / \mathrm{L}$ or $\mathrm{mmol} / \mathrm{L}$ as is customary.

3. Differences in application have a lot of influence on which quality measurements are important. Compost added to mineral soils is valued as a nutrient source and for immediate amelioration of physical properties. Compost added to organic mixes is valued for improving disease resilience.

4. Differences in delivery systems of water and nutrients and the rooting volume also influence the required properties. Systems with ample rooting volume and large storage capacity for water and nutrients value the nutrient supply by composts; systems with small rooting volumes and small storage capacity for water and nutrients depend more on frequent input of small quantities of water and nutrients.

5. The organic matter content needs to be reported in $\%-w / w$ for soil applications but in $\%-v / v$ for growers who are dealing with rooting materials other than mineral soils.

\subsection{References}

1. Blok, C., E. Rijpsma, and J.J.M.H. Ketelaars (2015).

New Growing Media and Value Added Organic Waste Processing. Acta Hort, in press.

2. Martínez, F., et al.(2013).

Effect of different soilless growing systems on the biological properties of growth media in strawberry.

Scientia Horticulturae, 150: p. 59-64.

3. Kleiber, T., B. Markiewicz, and A. Niewiadomska (2012).

Organic substrates for intensive horticultural cultures: Yield and nutrient status of plants, microbiological parameters of substrates. Polish Journal of Environmental Studies, 21(5): p. 1261-1271.

4. Blok, C., M. Aguilera, and E.A. Os, van (2009).

Validation of a New Phytotoxicity Test (Phytotoxkit) against an Established Four-Week Growing Test with Pre-grown Plant Plugs. Acta Horticulturae, 819: p. 209-214.

5. Raviv, M. and J.H. Lieth, Soilless Culture:

Theory and Practice. Soilless Culture. Theory and practise, ed. M. Raviv. 2008, Amsterdam, the Netherlands.

6. Wever, G., et al. (2005).

Bemestingsadviesbasis potplanten. Voor de Europese EN 1:5 volumemethode.

7. Whipker, B.E., T.J. Cavin, and W.C. Fonteno (2001).

$1,2,3$ 's of PourThru. FLOREX.005. 


\title{
9 How growers can assess compost quality?
}

\author{
Jacques G. Fuchs and Leen Janmaat
}

\section{In short}

- For the grower it is essential to choose the appropriate compost for the target application.

- A farmer can already acquire useful information about the compost quality using his own senses.

- Chemical analyses and biotests complete the information and allow the grower to evaluate and choose the right compost.

- A good relationship between compost producer and compost user is key to the successful implementation of compost in farming systems.

It is not always easy for a grower to choose the compost he wants to use. He has to select a compost that has been produced correctly and has good qualities for the intended application.

In this chapter, we will present to the grower some simple methods for performing an assessment on the composts.

\subsection{Compost sampling}

A very important point is that compost assessment should be based on a representative sample. To do this, samples are taken $30-40 \mathrm{~cm}$ inside the compost pile at different places and mixed together. An initial evaluation of the homogeneity of the compost can be carried out during this process. Observation of important differences between the subsamples (in regard to moisture content, colour, structure) can indicate whether the management of the composting process and/or the storage of the product was not optimally performed. In this is not the case, caution with the product has to be taken. Observations and analyses have to be performed with fresh samples. If not possible, the samples can be stored for 2 to 3 days at $4^{\circ} \mathrm{C}$.

\subsection{Assessments with own senses}

Observations of compost with own senses (eyes, nose, touch) can provide information about the compost quality. These observations cannot replace chemical analyses or plant tests, but they can complement them.

\subsubsection{Colour of the compost}

At the beginning of the composting process, the material presents a mosaic of colour deriving from the input materials. During the process, a homogenisation of the colour takes place, and, with the evolution of the humification, the compost becomes brown or blackish. If the compost is too dry during the process, grey moulds can be observed. 

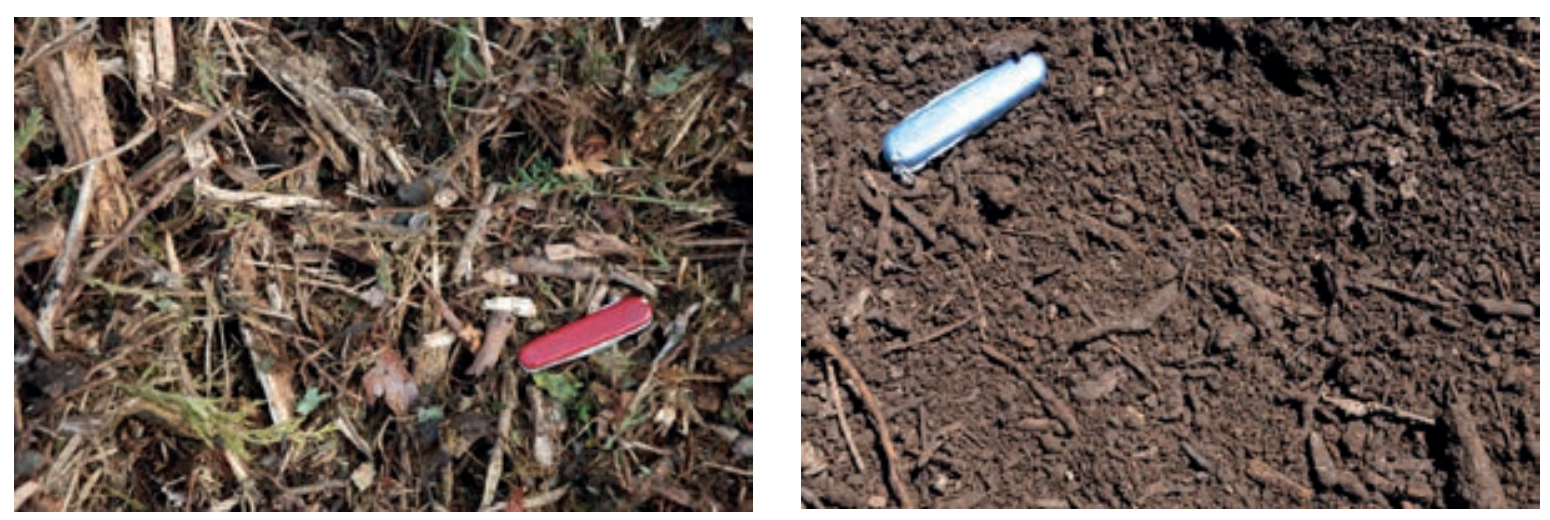

Figure 9.1 View of organic material at the beginning of the composting process (left) and mature compost (right).

\subsubsection{Odours}

Compost always smells but the odours can be more or less intensive and more or less agreeable depending on the management process. The odour of a compost depends on its maturity and on the process management. Young composts containing nitrogen-rich materials smell of ammonia, and will be transformed during the maturation processes into a product with the smell of forest soil.

Disagreeable odours such as that of "rotten eggs" or butyric acid are typical for poorly controlled anaerobic processes in the compost pile. Organic acids are formed as a result of oxygen starvation, and they cannot be transformed forward, which causes the emission of intens and disagreeable odours.

\subsubsection{Structure of the compost}

Mature compost produced by an optimal process has a crumbly structure and no recognizable starting material except for some wooden pieces. The presence of much fibrous material is a sign that the compost is not sufficiently mature. This can happen if the humidity content of the compost pile was too low especially in the hot phase. The ammonium present in the pile would therefore be lost as ammonia, leading to a shortage of $\mathrm{N}$ for the microorganisms and insufficient decomposition, even when water is available. When such a fibrous compost is applied, there is risk of nitrogen immobilization in the soil.
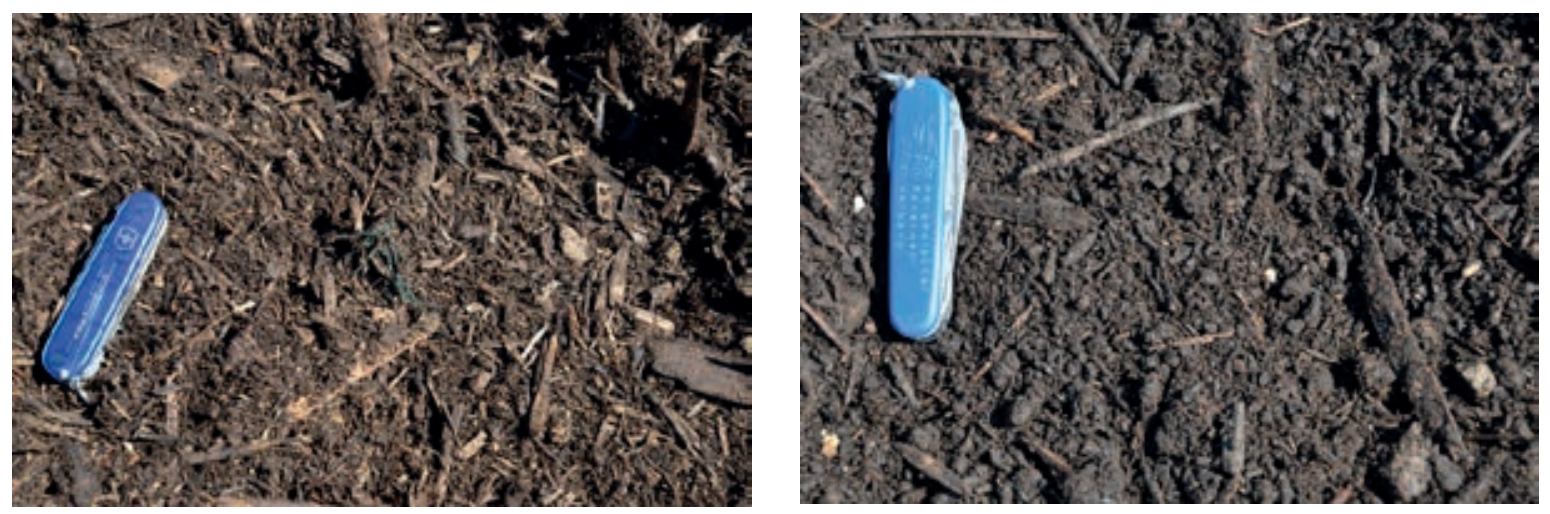

Figure 9.2 Fibrous compost (left) and crumbly compost (right). 


\subsubsection{Wood breaking test}

The wood breaking test also allows the characterization of the degree of maturity of the compost and the risk of nitrogen immobilization in the field after its use. Degradation of wood starts after the high temperature phase. Hence, we observe only minor degradation of wood in young compost, and clearly attacked wood in mature compost. If relatively raw wood is applied to a field soil, the microorganisms responsible for its degradation will immobilise the available nitrogen in the soil in order to perform the degradation. This nitrogen is therefore temporarily unavailable to the plants which inhibits their growth.

Table 9.1

Evaluation of the wood breaking test.

To test the degradation of wood, little branches with a diameter of about $10 \mathrm{~mm}$ are broken between fingers. The point of fracture is then observed.

\begin{tabular}{|c|c|c|}
\hline Compost & Observation of wood fracture & $\begin{array}{l}\text { Risk of nitrogen immobilization in } \\
\text { soil }\end{array}$ \\
\hline Young compost, in the heat phase & $\begin{array}{l}\text { Wood still hard, white to light- } \\
\text { colored, and no degradation signs } \\
\text { are observed }\end{array}$ & $\begin{array}{l}\text { Medium risk of nitrogen } \\
\text { immobilization over a relatively long } \\
\text { period }\end{array}$ \\
\hline $\begin{array}{l}\text { Young compost at the beginning of } \\
\text { the maturation phase }\end{array}$ & $\begin{array}{l}\text { Wood is slightly tender, darkening at } \\
\text { the margins and a little bit greasy }\end{array}$ & $\begin{array}{l}\text { High risk of nitrogen immobilization } \\
\text { over a relatively short period }\end{array}$ \\
\hline Mature compost & $\begin{array}{l}\text { Wood is tender, the surface of the } \\
\text { fracture is dark and the margins } \\
\text { black, and water can be easily } \\
\text { extruded by pressing the piece of } \\
\text { wood }\end{array}$ & Low risk of nitrogen immobilization \\
\hline
\end{tabular}

\subsection{Interpretation of measurements and analyses}

The compost user should obtain information from the compost producer that can be used in combination with personal observations to evaluate the compost.

\subsubsection{Composting process protocol}

Each compost producer has to follow a protocol about the composting process (see chapter 4). For the compost user, the most important point here is the control of the evolution of the temperature, in order to be sure that the compost is hygienically safe (chapter 4.1.1). This is the case if the compost reaches, after the last input of fresh organic material at least $55^{\circ} \mathrm{C}$ during three weeks or $65^{\circ} \mathrm{C}$ during one week, and if the compost pile is turned at least twice during the thermophilic period.

\subsubsection{Chemical analyses}

The compost producer has to periodically perform chemical analyses of his compost and these data can be requested from him. The first point to check is whether the heavy metals contents respect the legal limits (see chapter 4.2.1.3). To be able to plan the quantity of compost to be used and to calculate the nutrient balance, the nutrient analysis are also needed (see chapter 4.2.1.4). The heavy metals and nutrient contents are relatively stable during the composting process and do not need to be analyzed immediately before compost's use. The $\mathrm{pH}$-value (see chapter 4.2.1.5), the salt content (chapter 4.2.1.6), mineral nitrogen content (see chapter 4.1.4) and the phytotoxicity (see chap. 4.2.1.2) can greatly vary during the composting process and during the storage of the compost. For this reason, we recommend analysis of these characteristics a few days before using the compost. These analyses can be performed with a simple laboratory infrastructure (field labor). 


\subsubsection{Phytotoxicity tests}

Bio-tests (such as phytotoxicity tests) are very useful to complete the evaluation (see chap. 4.2.1.2). In such tests, plants react to the whole of the compost quality and not only to some parameters such as those mentioned above. The tests recommended are the open cress test (not so sensitive) and the closed cress test (highly sensitive).

\subsection{How to choose the right compost for the desired application}

Different quality requirements are needed depending on the planned utilization of the compost. We can classify the target utilisation into four groups:

- Compost to fertilize the crops

- Compost to improve organic matter in the soil and soil structure

- Compost to feed soil life and to improve its disease suppressiveness

- Compost as component of growing media

To be successful, the compost user has to interact with the compost producer in order to choose the appropriate compost for the planned utilization. Table 9.2 gives some global information to help the grower to choose the right compost. Of course, the different parameters can interact, and different soils and climatic conditions can also influence the reactions of composts following application. It is important to consider these points when performing a global evaluation of compost suitability.

\section{Compost Score}

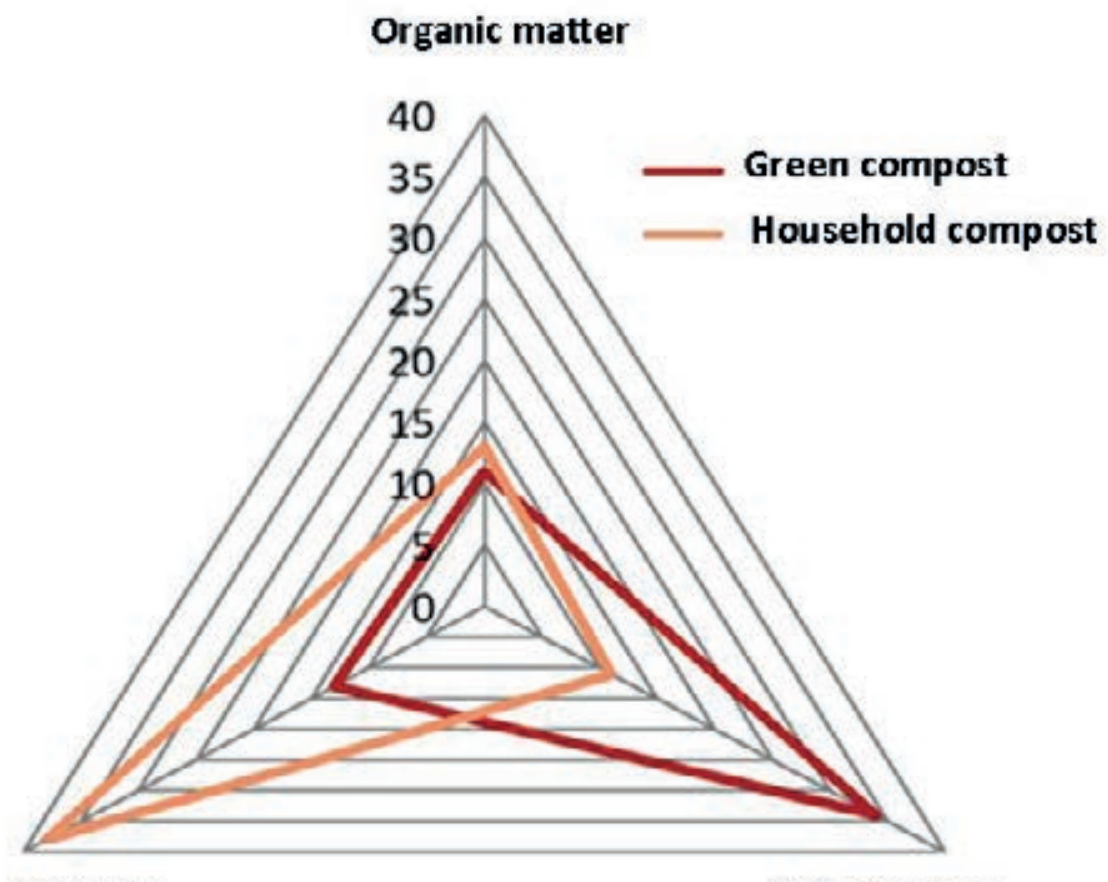

Minerals

Soil structure

Figure 9.3 The compost score: the interplay among organic matter, soil structure and minerals. Green compost is indicated in red and household compost in orange. Green compost has a stronger effect on soil structure, while household compost contains more minerals for fertilization purpose.

The long term effect of compost on organic matter (OM) in the soil depends on the carbon/nitrogen $(\mathrm{C} / \mathrm{N})$ ratio and on the origin of the carbon. More woody compost has more effect on the organic matter. 
Table 9.2

Evaluation of the suitability of a compost for different use target.

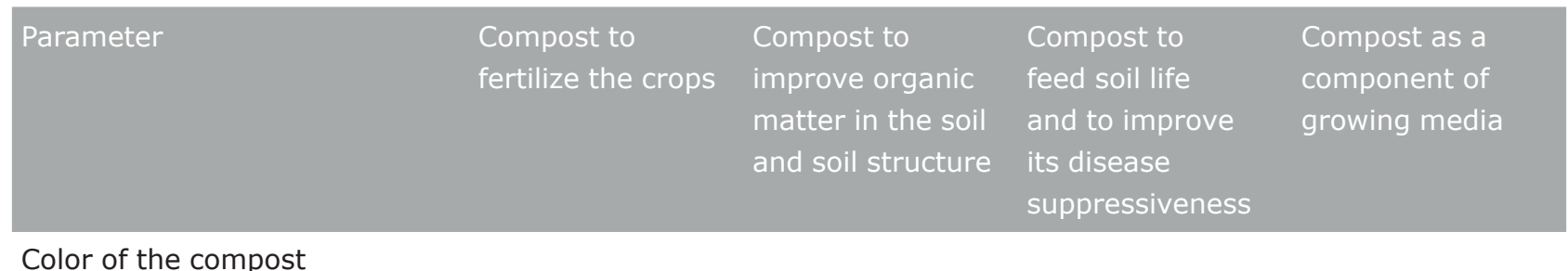

mosaic of colors

homogeneous color, brown to ++

$++$

$+$

$+$

blackish

\section{Odours}

ammonia

bad (e.g. rotten eggs)

forest soil

$\begin{array}{ll}+ & - \\ -- & -- \\ + & ++\end{array}$

0

$--$

$--$

Structure of the compost very fibrous

crumbly

$\begin{array}{ll}-- & 0 \\ ++ & ++\end{array}$

0

$+$

$-2$

Wood breaking test

wood still hard, white to light-

colored, no degradation signs

wood is slightly tender,

darkening at the margins and a ++

$-$

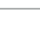

$+$

little bit greasy

wood piece tender, the surface

of the fracture is dark and the

margins black

Process temperature

$<55^{\circ} \mathrm{C}$ during 3 weeks or $65^{\circ} \mathrm{C}$ -

during 1 week, and/or the

compost pile has not be turned +

$>55^{\circ} \mathrm{C}$ during 3 weeks or

$65^{\circ} \mathrm{C}$ during 1 week, and the

compost pile has to be turned

$2-3 x$

\section{Heavy metals content}

does not respect legal limits

respect legal limits

$\begin{array}{ll}-- & - \\ ++ & ++\end{array}$

$+$

$-$

$\mathrm{pH}$ value

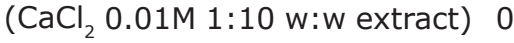

$>7.8$

$7.5-7.8$

0

$<7.5$

salt content

( $\mathrm{H}_{2} \mathrm{O}$ 1:10 w:w extract)

$>20 \mathrm{gKleq} / \mathrm{kg}$ TS

$10-20 \mathrm{gKleq} / \mathrm{kg}$ TS

$-$

0
+

$--$

$+\quad+$

$++$

$<10 \mathrm{gKleq} / \mathrm{kg}$ TS

$\mathrm{N}_{\min }$

( $\mathrm{CaCl}_{2}$ 0.01M 1:10 w:w extract) --

$<100 \mathrm{mg} \mathrm{N} \mathrm{min}_{\text {min }} / \mathrm{kg}$ TS

$100-160 \mathrm{mg} \mathrm{N}_{\min } / \mathrm{kg}$ TS

$+$

$>160 \mathrm{mg} \mathrm{N}_{\min } / \mathrm{kg}$ TS

$\mathrm{NO}_{3}-\mathrm{N} / \mathrm{N}_{\min }$

$<0.4$

$0.4-0.8$

$>0.8$

$\begin{array}{ll}-- & 0 \\ 0 & 0 \\ ++ & 0\end{array}$

0

0

0

$--$

$\begin{array}{lll}0 & 0 & - \\ 0 & 0 & +\end{array}$




\begin{tabular}{lllll} 
Parameter & $\begin{array}{l}\text { Compost to } \\
\text { fertilize the crops }\end{array}$ & $\begin{array}{l}\text { Compost to } \\
\text { improve organic } \\
\text { matter in the soil } \\
\text { and soil structure }\end{array}$ & $\begin{array}{l}\text { Compost to } \\
\text { feed soil life } \\
\text { and to improve }\end{array}$ & $\begin{array}{l}\text { Compost as a } \\
\text { component of } \\
\text { growing media } \\
\text { suppressiveness }\end{array}$ \\
Phytotoxicity: open cress test & & & \\
$<50 \%$ from control media & 0 & & -- & -- \\
$50-75 \%$ from control media & 0 & 0 & 0 & -- \\
$>75 \%$ from control media & 0 & 0 & ++ & + \\
\hline $\begin{array}{l}\text { Phytotoxicity: closed cress test } \\
<25 \% \text { from control media }\end{array}$ & 0 & 0 & & -- \\
$25-50 \%$ from control media & 0 & & 0 & 0 \\
$>50 \%$ from control media & 0 & 0 & + & ++ \\
\hline
\end{tabular}

--: not appropriate for this use; 0 : not relevant; ++: appropriate for this use 
Handbook for Composting and Compost Use in Organic Horticulture | 105 
106 I Handbook for Composting and Compost Use in Organic Horticulture 

COST (European Cooperation in Science and Technology) is a pan-European intergovernmental framework. Its mission is to enable break-through scientific and technological developments leading to new concepts and products and thereby contribute to strengthening Europe's research and innovation capacities. It allows researchers, engineers and scholars to jointly develop their own ideas and take new initiatives across all fields of science and technology, while promoting multi- and interdisciplinary approaches. COST aims at fostering a better integration of less research intensive countries to the knowledge hubs of the European Research Area. The COST Association, an International not-for-profit Association under Belgian Law, integrates all management, governing and administrative functions necessary for the operation of the framework. The COST Association has currently 36 Member Countries. www.cost.eu.

Link to the Action:

http://www.cost.eu/COST_Actions/fa/FA1105

And:

http://www.biogreenhouse.org/ 